\title{
Essays In
}

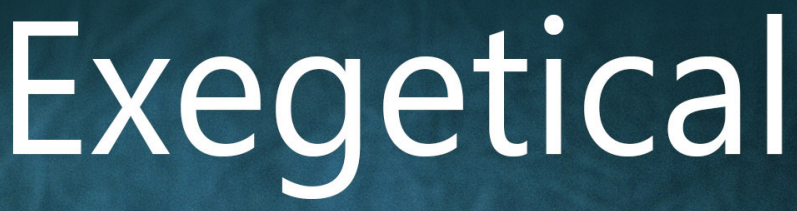

Christology

FREDERICK MAWUSI AMEVENKU \&

ISAAC BOAHENG

Reviewed by S. V. Mpereh

(O)Noyam 


\section{Essays In \\ Exegetical \\ Christology}

Frederick Mawusi Amevenku \& Isaac Boaheng

Reviewed by S. V. Mpereh

(9)Noyam

PUBLISHERS

Accra, Ghana 


\section{Essays In Exegetical Christology}

Frederick Mawusi Amevenku and Isaac Boaheng

Copyright (C) 2020 Noyam Publishers.

ISBN 978-9988-53-915-3

DOI: $10.38159 /$ npub.eb20604

Published in Ghana by

Noyam Publishers

All rights reserved. No part of this publication may be reproduced

or transmitted in any form or by any means, electronic or mechanical, including photocopying, recording, or any information storage

and retrieval system, without permission in writing from the publisher.

For further information or permission, contact:

Noyam Publishers

P.O. Box 165 La, Accra-Ghana

Contact Number: +233 593142920

Email: publications@noyam.org

Website: www.noyam.org 
This book is dedicated to the memory of the late Very Rev. Dr. Samuel V. Mpereh, who devoted a substantial portion of his ministry life to teaching students of Trinity Theological Seminary Ghana Greek and New Testament studies 


\section{ACKNOWLEDGEMENTS}

The preparation of a book involves the contribution of many people, often too numerous to mention. This book is no exception. Those to who we are indebted include the many authors whose writings offered us various insights to help shape our own thoughts in this book. To all such authors, we are deeply grateful. They remind us of the African proverb which says knowledge is as wide as a baobab tree, therefore no individual can embrace it.

We are profusely indebted to the late Very Rev. Dr. Samuel V. Mpereh who set aside time from his busy schedule to review the manuscript for us. We regret that he did not live to see the publication of the work. To honour his memory, we have decided with permission from his family, to write the foreword in his name to acknowledge the role he played to make the preparation of the book successful.

Finally, we wish to thank our publishers and their staff for their contribution at the various stages of transforming the manuscript into the book you are presently reading. May the Lord, prosper your publication work to enable you to continue to contribute to publication excellence in Africa. 


\section{CONTENTS}

DEDICATION iv

ACKNOWLEDGEMENT V v

CONTENTS vi

FOREWORD vii

PREFACE

INTRODUCING THE STUDY 1

\section{CHAPTER ONE}

EARLY CHRISTOLOGICAL CONTROVERSIES 11

\section{CHAPTER TWO}

THE OLD TESTAMENT AND CHRISTOLOGY

\section{CHAPTER THREE}

LOGOS CHRISTOLOGY (JOHN 1:1)

\section{CHAPTER FOUR}

INCARNATION CHRISTOLOGY (JOHN 1:14a)

\section{CHAPTER FIVE}

HUMILIATION-EXALTATION CHRISTOLOGY (PHIL. 2:5-11)

\section{CHAPTER SIX}

FIRSTBORN CHRISTOLOGY (COL. 1:15-20)

\section{CHAPTER SEVEN}

PRIESTLY CHRISTOLOGY IN HEBREWS

SUBJECT INDEX 


\section{FOREWORD}

Jesus is Lord. Jesus is King. Jesus is the Son of God. Jesus is the Saviour of the world. Jesus is the Liberator. Any of the responses in the preceding two lines is a potential answer to the question, "Who is Jesus?" The main task of this book is to answer this question. Who is Jesus? The answer one gives to this question determines how he or she practices Christianity, because it invites a particular attitude towards and relationship with Jesus.

Knowing Jesus appropriately is not a mere academic desire. It is also the quest of the Church. Above all, the general culture, comprising citizens of the world who do not necessarily subscribe to the Christian faith, also wants to know who Jesus is. Thus, the quest for knowing the true identity of Jesus is a universal one.

Amevenku and his former student Boaheng, seek to satisfy this quest. They convincingly argue that the historical Jesus of Nazareth presented in the Gospels and interpreted in the Epistles/ Letter of the New Testament, is none other than the Christ of God, who was promised and implicitly revealed in the Old Testament before his incarnation into human history in first century Palestine. This Jesus is best understood by explaining the perspectives of various New Testament writers on him. Such understanding leads to a fruitful relationship with Jesus the Christ.

By means of exegesis, the authors engage the original Greek text of selected passages to point out those aspects of Christology that selected biblical authors emphasise. By so doing, they bring freshness to the discussion and clarify their own perspective on the various aspects of Christology. This book is therefore, useful both for the study of exegesis and Christology. It is recommended for students of theology, pastors and academics. The authors are highly commended for their untiring effort in writing this book both to glorify God and 
to educate people. This is a worthy contribution to both theological scholarship and Christian ministry. May the Lord's name be praised! 


\section{PREFACE}

Organised in seven chapters, Essays in Exegetical Christology assembles useful data from different parts of the Bible to proffer a response to the question, "Who is Jesus?" The answer does not have to be a single one, however, because there are many perspectives from which to view Jesus, as the opening lines of the foreword suggest.

The opening chapter underscores numerous controversies in the history of the Church regarding the identity of Jesus Christ. The authors evaluate the main arguments to show what each viewpoint has to commend it and what is to be rejected in each. In recognition of the fact that the incarnation of Jesus in the New Testament fulfills Old Testament prophecy, the authors take up the Old Testament promises and allusions to the Messiah in the second chapter.

In the subsequent chapters, the authors discuss the perspectives of the authors of John's gospel, Philippians, Colossians and Hebrews on the identity of Jesus Christ. Chapter three focuses on the preexistence of Christ and chapter four on the incarnation of Christ. Chapters five, six and seven examine the Christology of humiliationexaltation, primogeniture, priesthood respectively.

The book demonstrates that a holistic understanding of the identity of Jesus the Christ, serves to clarify his claim to be the Son of God even though the New Testament authors hesitate to use the title "God" directly for Jesus. Knowing Jesus as fully God and fully human validates his vocation as Saviour and justifies all human quests to go to him to find rest for their restless souls. 
THIS COPY IS NOT FOR SALE

Essays In Exegetical Christology | x 


\section{INTRODUCING THE STUDY}

Christology is central to the study of Christian Theology. Knowing who Christ is, and what he does, is thus, a crucial part of Christian reflection on God and the works of God in the world. Who is Jesus Christ? Why is Christ so important for the Christian faith? The Christian doctrine of the person of Christ (Christology) sets out to answer these and other questions related to the person and works of Christ. Answers to these questions are very important because one's view of Christ determines how he/she understands and practices Christianity. As a matter of fact, Jesus Christ is the historical point of departure for Christianity.

Discussions of Christology could be traced to the time of Jesus. According to the gospel account, Jesus once asked his disciples: "Who do people say I am?" (Matt. 16:13; Mark 8:27). It is clear from this question that in his life time people had already begun to speculate about who the Christ was. After the disciples reported people's opinion about Jesus of Nazareth, Jesus asked, "But who do you say that I am?" (Matt. 16:15). Peter's response that Jesus is the Christ, the Son of the living God (v. 16) became the rock upon which Christ promised to build his church (v. 18ff).

Reading this and other gospel passages, one realises that even though the identity of Christ was vague to the disciples at the initial stages of their fellowship with him, they (the disciples) gradually became aware of the theological significance of who the Saviour was. We may as well conclude that Christianity began at this point in the life of Christ. Paul Tillich, therefore opines that, "Christianity was born, not with the birth of the man called 'Jesus,' but in the moment in which one of his followers was driven to say, 'You are the Christ."'

Paul Tillich, Systematic Theology, vol. 2 (University of Chicago Press, 1957), 97. 


\section{Why this book?}

The Christological question has attracted much scholarly attention throughout the history of the Christian Church. Theologians seem to have so much interest in the subject that, they tirelessly write on it. Publications on the subject of Christology are therefore numerous. However, most of these works tend to focus mainly on the historical perspective of the subject, and fail to pay adequate attention to the biblical data available. Others focus so much on so many biblical passages that they are unable to study these texts into details. What makes the present work unique is its ability to offer detailed analyses of selected biblical passages, without neglecting the historical aspect of the subject matter.

\section{Approach used by this book}

Through exegetical reading of selected texts, this book brings out deep insights into biblical teachings about the person and works of Christ. By way of definition, biblical exegesis is the interactive process of arriving at the meaning of biblical texts in their original contexts. ${ }^{2}$ Michael J. Gorman identifies three main categories of exegetical approaches namely, synchronic approach (including narrative criticism, social-scientific criticism and social-rhetorical criticism), diachronic approach (historical-critical method) and existential approach. ${ }^{3}$ The synchronic approach deals mostly with the final form of the text as we have in the Bible. This approach uses various methods to analyze the text in relation to the world in which it first appeared. ${ }^{4}$

The diachronic approach deals with the origins and developments of a text. It also examines how a text changes and develops with time. Gorman compares this method with the

\footnotetext{
2 Michael J. Gorman, Elements of Biblical Exegesis: A Basic Guide for Students and Ministers (Grand Rapids, MI: Baker Academic, 2010), 10-13

3 Gorman, Elements of Biblical Exegesis, 12.

4 Ibid., 13.
} 
longitudinal section of a plant stem because it takes a "long view" of the text. ${ }^{5}$ It includes textual criticism, form criticism, tradition criticism, source criticism, and historical criticism. The diachronic and the synchronic approaches are both "interested in the historical or socio-political contexts in which the text comes to life and the kind of literature texts are."

The existential approach takes no interest in diachronic or synchronic reading of the text. It rather engages the text itself and tries to deduce the reality beyond it as testified in the text. This method uses the text not as an end in itself but a means to an end. This approach is self-involving because "readers do not treat the text as a historical or literary artifact but as something to engage experientially_-something that could or should affect lives."7

Our approach could be described as the use of linguistic and diachronic analyses to clarify the meanings of selected key Bible texts as they apply to Jesus and his work. We have therefore, not paid so much attention to the historical development of Christology. The approach used in this volume comprises the following key steps: (a) Contextual analysis (b) Literary analysis including a study of the form (genre), structure and movement of the text (c) detailed analysis of key parts of the text involving lexicology (the meaning of words), morphology (the form of words), grammatical function of words (parts of speech), syntax (the relationships of words), figures of speech etc, and (d) theological synthesis of the findings

\section{Defining Christology}

Oscar Cullmann asserts that "If theology is that science whose object is God, then Christology is that science whose object is Christ, his person and work." ${ }^{\prime 8}$ Christology refers to the aspect of theology that deals with the person of Christ as the Redeemer of humankind. Strictly

\footnotetext{
5 Gorman, Elements of Biblical Exegesis, 15.

6 Ibid., 17.

7 Ibid., 18.

8 Oscar Cullmann, The Christology of the New Testament (London: SCM Press Ltd., 1967), 1.
} 
speaking, the person and works of Christ are inseparable. Christ and his work are united. Christ qualifies as Saviour because of who he is. Because he is the Christ, true Christology is rooted in the objective experience of Christ as he is known by the apostles, recorded in the Gospels and interpreted in the rest of the New Testament under the inspiration and illumination of the Holy Spirit. As such, the Gospels are foundational to the subject of Christology in that they give us knowledge about how Christ, incarnated to reveal to people the nature of God. Yet, New Testament Christology can only be understood fully if it is studied in the light of the Old Testament. Taking cognisance of this, the present work devotes one chapter to the study of key aspects of Christology from Old Testament perspective.

Christology is not an independent, philosophical, historical or mythological reflection. Rather, it is born out of theological, cultural or social contexts. All confessions of faith and proclamations about Christ deal with the life and ministry of Jesus as the Messiah promised in the Old Testament, who has fulfilled the Law and Prophets (Matt. 5:17) in the New Testament and in whom God is revealed to humanity in the fullest sense. Christology is therefore, "both history and reflection." Reflections about Christ in every epoch have encountered other thoughts and mythologies, which ultimately affect the beliefs of people of that epoch. Thus, the historical and reflective aspects of Christology have always been scrutinized by independent treatment. Nonetheless, Christological confessions and proclamations are not meant to have support from such independent treatment. Strictly speaking, Christological reflections seek to find answers to the question of who Jesus is, and what he does, based not on independent, experimental reflections but on a "definite body of knowledge and definite proclamation." ${ }^{10}$ Christological reflection answers a question of faith rather than independent personal reflections. For this reason, our Christological formulations, like any other theological formulations, must have the word of God as their

\footnotetext{
Regin Prenter, Creation and Redemption translated by Theodor J. Jensen (Philadelphia: Fortress Press, 1967), 291.

${ }^{10}$ Ibid., 292.
} 
final authority.

\section{Methods of Christology}

Earlier we stated that we have employed the exegetical reading of texts in this book. This method focuses on how meaning is drawn from texts and applied to life situations. What we are considering at the moment is how one approaches the whole subject of Christology; that is, whether one begins with Christ's preexistence or his incarnation. In this regard, scholars have identified two methods of studying Christology, namely, "Christology from above" (high or descending Christology) and "Christology from below" (low or ascending Christology). "Christology from above" begins with the pre-existent state of Christ, and from there seeks to illuminate how the divine Word of God took on humanity (incarnation). "Christology from below", on the other hand, begins with Jesus as the baby in Bethlehem and the man from Nazareth, and then seeks to illuminate how this man was truly God. This kind of Christology starts from the earth. It begins with human experience, with human questioning, with the historical Jesus of Nazareth, and with the accounts of the disciples who encountered Jesus.

The Christological approaches adopted by the Synoptics (Matthew, mark and Luke) on one hand and the fourth gospel on the other hand are different. In the Synoptics, Christology begins with a human being, who is revealed as the Christ only in history, particularly in the resurrection. John presents a descending Christology while the other gospel writers and Paul present an ascending Christology. ${ }^{11}$ The synoptic gospel writers moved from the historical Jesus to the divine Son of God. They fixed their eyes on the resurrection and constructed their stories backwards over Jesus' life. ${ }^{12}$ Matthew begins with Jesus' genealogy, Mark with his baptism, Luke with his unusual birth. John, on the other hand, takes the reader further back into eternity when the

\footnotetext{
${ }_{11}$ John Macquarrie, Jesus Christ in Modern Thought (Philadelphia: Trinity Press International, 1990), 98.

12 Ibid.
} 
Logos co-existed with the Father and possessed the Father's nature as well (1:1). In John, we get to know the state of the Logos before the world began. Christology from above was a common ancient method for studying Christology. ${ }^{13}$ John might therefore, have been familiar with this method of Christology which he applies perfectly in his gospel. John's method influenced the Christology of the early church. Among the Church Fathers, this method became very useful, especially in Alexandrian Christology. ${ }^{14}$

The designations "from above" and "from below" are not to be understood as the end, goal, or result of Christological thinking but "as the distinctive quality of the Christology that is being described." ${ }^{15}$ The term "from" in the expression "from above" or "from below" simply refers to the point of departure in our thinking. The two Christological methods are not mutually exclusive. They are interdependent in that Christology "from above" is based on God's eternal being, while Christology "from below" is rooted in our human means of knowing. The methods are therefore not options for us to choose from. We need to embrace them together if our Christology is to be balanced and complete. Overemphasis on Christology from above can lead to Sabellianism, Docetism, Monophysitism, or Monothelitism. All these approaches to Christology stress Christ's divinity so much that his humanity is lost. On the other hand, overemphasis on Christology from below can lead to Ebionitism, Adoptionism, Nestorianism, or Arianism. All these approaches to Christology, to some extent, deny the divinity of Christ.

\section{Importance of Christology}

The subject of Christology is relevant for theological, biblical, hermeneutical and practical reasons. Theologically, Christology stands at the centre of Christian theology. All major Christian

\footnotetext{
${ }^{13}$ Wolfhart Pannenberg, Jesus-God and Man translated by Lewis L. Wilkins and Duane A. Priebe (Philadelphia: The Westminster Press, 1964), 33.

${ }^{14}$ Ibid.

${ }^{15}$ Roger Haight, The Future of Christology (Bloomsbury: A\&C Black, 2005), 33.
} 
doctrines relate to the person and works of Christ. Theology aims at determining the nature, will and purpose of God, restated for contemporary relevance. Christian theology and ministry must discern how the whole Scripture corresponds to Christ because God's being has fullest revelation in Christ (See John 14:9; Col. 1:15; 2:9; Heb. 1:3). If so, then any theological affirmation that contradicts the life and ministry of Christ is unacceptable. For example, Eschatology, which deals with last things, cannot be understood without referring to Christology. It is Christ's past work on the Cross that gives us the hope that when he returns, we will not be condemned. The future judgment will be done by Christ and he will reign forever in the new heaven and earth. More so, Christ's death and resurrection are central to a successful study of Soteriology (the doctrine of salvation). In Anthropology, the study of human beings, Christ is presented as the truest human being that has ever lived. He is the Creator of humankind and the best example for human living.

Biblically, the whole Bible is centred on Christ. The OT prepares us for his coming and the NT centres on his life and ministry as recorded in the gospels and interpreted by the early church. As the central figure of the Bible, almost all parts of the Bible have something to say about him.

Hermeneutically, it has been contended that Christ is the centre of Biblical hermeneutics. ${ }^{16}$ Christ (re)interpreted Scriptures during his earthly ministry (Matt. 5:21-48; Luke 24:44-47) to give better understanding of many OT passages. Therefore, in our interpretation of Scripture, we must give priority to what Jesus taught. This approach to hermeneutics is very effective, for instance, when used in discerning and explaining the theology of the imprecatory Psalms (such as Ps. 35; 109). From the perspective of Christ, God wants us to love (pray for and wish them well) our enemies rather than hate them (cf. Matt. 5:43-46). In this case, Christ's teaching becomes the hermeneutical plumb line for "straightening" other teachings. Yet

${ }^{16}$ See C. L. Peppler, "The Christocentric Principle: A Jesus-Centred Hermeneutic" Conspectus 13 no. 1 (2012):117-135 and K. G. Smith, "The Christocentric Principle: Promise, Pitfalls, and Proposal. Conspectus 13 no. 1 (2012):157-170. 
it is impossible to preach Christ from every Bible text. ${ }^{17}$ The Bible was progressively revealed to humankind. Preaching Christ from every biblical text has the tendency of landing one's theology into the dangers of allegory. Therefore, the Christocentric approach to hermeneutics should be restricted to matters that are revealed in the life and ministry of Jesus, the Christ, to avoid creating a canon within a canon and distorting the portrait of Christ.

Religiously, Christ is at the centre of Christianity. To be a Christian, one must have a personal encounter with Christ. This makes Christianity different from other religions of the world. One becomes a Christian when he/she is saved by Christ. Salvation depends on the person and works of Christ and can only become fully complete when Christ returns. Most Christian activities are centred on Christ. We pray through him; he is the object of our worship and the central figure in Christian Eucharist (Holy Communion). Major Christian festivals such as Christmas, Good Friday and Easter are all Christocentric. Christians can face death because of the hope of resurrection which is founded on Christ's own resurrection from the dead.

Practically, Christ is the best example for our lives. As the perfect revelation of God, Christ is the one whose life example we need to follow. Paul knew this fact and so exhorted his audience to follow his example of following Christ (1 Cor. 11:1). Having been tempted and yet remaining sinless, Christ is in the best position to help us overcome our own temptations and sins. The way to attain this kind of benefit from Christ is to learn about his person, works and will.

\section{Overview of the book}

This book has seven chapters apart from the general introduction to the study. The first chapter focuses Christological controversies that

${ }_{17}$ B. Chapell, Christ-Centered Preaching: Redeeming the Expository Sermon. Kindle 2nd ed.
(Grand Rapids: Baker Academic, 2005) 
characterized the early church. Among other things, this chapter helps the reader to know mistaken views about Jesus and to guard against such views in our time. The second chapter examines some aspects of Old Testament Christology and comes out with the main argument that even though the Old Testament does not explicitly reveals the Christ, the concept of the Messiah is present and consistently points to Jesus the Christ.

The next chapter, building on the Old Testament foundation of Christology, focuses on the contribution of the first verse of John's gospel to Christology, by considering the text within the context of John's prologue (1:1-18), and closely linking it with 1:14 which marks the movement of "the logos" from its pre-incarnate state $(1: 1)$ to the point of incarnation. Following this chapter is a critical examination of the Christological thoughts expressed in the expression "Kai ho Logos sarx egeneto" (John 1:14a). The main point of the chapter is that any Christology that does not balance the humanity and divinity of Christ is theologically unacceptable.

In chapter five the work examines one of the Christ-hymns in the New Testament (Phil. 2:6-11) with special attention to the humiliation and exaltation motif of Christology. The sixth chapter argues that by designating Christ as prototokos pases ktisis (Col. 1:15), Paul considered him as the source of creation rather than being first-created. Finally, the seventh chapter considers the priestly role of Christ. Here, the book throws light on the relationship between the new and old covenants, the interpretation of the Old Testament and the subject of faith. 


\section{Review Exercise}

1. What is meant be the term Christology? How relevant is Christology to the life of the Church?

2. Explain, with relevant examples, the differences between Christology from above and Christology from below.

3. Is the subject of Christology relevant at all? Explain your answer.

4. How does the question "Who do people say I am?" inform our understanding of Christology?

5. Examine how a balanced view of Christology should inform the ethical principles of Christians. 


\section{CHAPTER 1 EARLY CHRISTOLOGICAL CONTROVERSIES}

Early history of Christianity is full of controversy over Christ's person and work. The main issue in the controversy was: what is the relation between the two natures of Christ, his human and divine natures? This question also relates to the relationship between Christ's nature and God's nature. Attempts by the Church to answer these questions gave rise to various forms of Christological heresies which threatened orthodox Christianity. In what follows we outline major heresies that came up and how they were resolved.

\section{Ebionism}

Ebionism emerged in the second century with the proposition that Christ is solely human. ${ }^{18}$ The Ebionites were an offshoot of Jewish Christians, who were very influential in the apostolic age. The word Ebionite comes from the Hebrew ebionim, meaning "the poor ones." They were people who had voluntarily chosen to be poor (voluntary poverty). They observed the Law strictly and argued that salvation could not be obtained through faith alone. They identified with the legalistic tendencies we find in the NT. The Jerusalem Council's dealing with the problem of the Law (cf. Acts 15), and Paul's teachings in Galatians in which he contrasts the teachings of the Judaizers with the covenant of grace (Gal. 3) point to such legalistic tendencies. The challenge of reconciling the deity of Christ with strict Jewish monotheism made Ebionites reject the idea that Christ is God. Thus, for Ebionites, Jewish monotheism is irreconcilable with

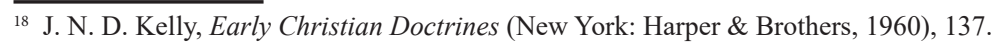


the Trinitarian doctrine of Jesus' divinity. Ebionism denied the Virgin birth of Christ and taught that Joseph and Mary were Jesus' biological parents. ${ }^{19}$ They taught that an unmeasured fullness of the Spirit was given to Jesus at his baptism and this made him the Messiah who will return to the earth and rule. ${ }^{20}$ To them, Christ's moral excellence was the reason for which God was revealed in him. Jesus, according to Ebionism, is a great prophet, the only person who perfectly obeyed God's Law. An offshoot of Ebionism, called Nazarenes, disagreed with the Ebionites proper in acknowledging the miraculous virgin birth of Jesus. As more Gentiles got converted into Christianity the influence of the Ebionites reduced. Later, the outbreak of Jewish war (c. 66 AD) dispersed the Jews from Jerusalem, making them completely isolated. ${ }^{21}$ Not much is recorded about the Ebionites after the war, even though the Nazarenes, continued their strict obedience to the Law. ${ }^{22}$

\section{Docetism}

Another solution to the Christological question was proposed by Docetists. From the Greek dokein meaning "to seem" or "to appear", Docetism held that Christ only appeared to be human but was not truly human. He was some form of mystical spirit, a pure heavenly body who had no real human body. It follows that his sufferings, death and resurrection were not real events. Kelly attributes the source of this view to "Greco-Oriental assumptions about divine impassability and the inherent impurity of matter." 23 Docetic teachings, resulting from pagan philosophy, was rejected by many Christians because it made the incarnation of the Logos meaningless. Ignatius of Antioch, Polycarp, Irenaeus, and Hippolytus all condemned docetism. Docetism gave rise to other heresies such as Marcionism and Gnosticism.

\footnotetext{
19 Paul L. Maier, Eusebuis The Church History: A New Translation with Commentary (Grand Rapids, MI: Kregel Publications, 1999), 116.

${ }^{20}$ Kelly, Early Christian Doctrines, 137.

${ }^{21}$ Ibid.

22 Ibid.

${ }^{23}$ Ibid., 141.
} 
Gnosticism ${ }^{24}$ began before Christianity. In the New Testament, hints about Gnosticism can be found in Colossians 2 (see v. 9) and 1 \& 2 John. Its origins can be found in Hellenistic thinking and to some extent also in Judaism even before the Christian period. The most basic features of the movement were: (1) a radical dualism between spirit and matter, (2) belief in a Demiurge ${ }^{25}$ ("an inferior and foolish being") who created the world and (3) redemption of the inner, spiritual man from matter by way of superior, revealed knowledge. ${ }^{26}$ Salvation in Gnosticism means escaping from the body and from the world of space and time in which the body has imprisoned the soul. The Demiurge, according to Gnostics, is the God of the OT. The supreme God, for Gnostics, is completely alien to the physical universe. They claimed that they, not the Church, were the true Christians.

The Gnostic belief system taught that God is good but matter is evil, that Jesus Christ was merely one of a series of emanations descending from God (a belief system that led to denial of Christ's humanity), and that a secret higher knowledge was necessary for enlightenment and salvation. Thus, Gnosticism taught that flesh and physical matter hindered and corrupted the spirit. From this view, it is impossible for God, who is spirit, to trap Himself in human flesh. On this premise, Gnostics rejected any literal interpretation of "The word became flesh" (John 1:14). They denied that Jesus is the Messiah (1 John 2:22) and that he had come in the flesh (1 John 4:2-3; 2 John 7). Prominent names commonly associated with Gnosticism are Basilides, Valentinus and Cerinthus.

Marcionism, another offshoot from Docetism, held that Jesus' body was phantasmal. Marcion (the founder of Marcionism) and his follower Apelles replaced the incarnation doctrine with the idea that Jesus came without birth but directly from heaven. For them, Christ was a heavenly being who entered the world without birth. Marcion taught that Jesus' death was meant for the redemption of human souls

\footnotetext{
${ }^{24}$ Gnostic comes from the Greek word gnosis meaning "knowledge."

${ }^{25}$ The Demiurge is sometimes associated with the God of the OT.

${ }^{26}$ N. R. Needham, 2000 Years of Christ's Power: The Age of the Early Church Fathers (London: Grace Publications Trust, 2002), 95-96.
} 
(not bodies). He wrote Antiteses in which he enumerated what he believed were contradictions between the OT and the NT. He went further to produce his own NT. For Marcion, the God of the OT cannot be the same as the God of the NT. In his version of the NT, Marcion threw out every Jewish element, accepting only Luke's gospel and some of Pauline epistles.

\section{Arianism}

The Arian controversy, or Arianism, was the greatest Christological controversy in the life of the Church. The controversy was carried on in Greek, and as expressed in Greek the whole question turned upon a single letter. The word which expressed Alexandrian Christology was homoousion (of the same substance) while the Greek word homoiousion (of similar substance) expressed the belief of Arius (256-336), an Alexandrian presbyter. One of the words has two 'i's' in it, and the other has but one. The controversy became known as the i-controversy. The question in contention was whether the Son of God is of the same substance, or only of like substance, with the Father. In the fourth century (c.a 319) Arius, who was educated by Lucian in Antioch began to project his doctrine that the Son was not of the same substance with the Father, but was rather created by the Father before the beginning of the world ${ }^{27}$ as the first and highest of all God's creation. That is, even though the Son may be said to be like the Father or similar to the Father, in his nature, he is not of the same nature as the Father. As an absolute transcendent being, taught Arius, the Father could not create the world directly but only indirectly through action of the Son. The Son, according to Arius, is closer to the Father than any other creature and, any other creature came into being through the Son. There was a time when Christ was not and he was created out of nothing.

Again, Arius taught that the Holy Spirit was the first thing created by the Son, since all other things were made by the Son.

\footnotetext{
${ }^{27}$ Needham, 2000 Years of Christ's Power, 201.
} 
Therefore, according to him the Son is a heavenly being who existed before the rest of the creation and he is also far greater than any other creation, yet he is not equal to the Father nor his attributes. Arius further argued that the Father alone is God and that was the only means for maintaining that there is only one God. In his view, a belief in the deity of Christ amounted to the belief in two Gods, which is unbiblical. It seems this kind of teaching was the result of the misinterpretation of the scriptural accounts of Christ's state of humiliation as well as the misinterpretation of his temporary subordination to the Father as original and permanent inequality.

Before Arius, Origen had expressed the view that there could be grades or degrees in divinity and that the Son's divinity was slightly less than the Father's. Origen was very influential in the Christological position of the East. He contended for the view that the Son's essence was different from the Father and that the Son was subordinate to the Father. He stood for the eternal generation of the Son from the Father and used the term homoosios. Origen taught also that the Son was an intermediary who closed the gap between the transcended God and the created world. Arius might have been influenced by the teachings of Origen. His teachings aimed at maintaining the monotheistic teachings of the OT ("Monarchianism"). Only the Father was regarded as eternal and without a beginning. The Son who was "begotten" (Prov. 8:22; Col 1:15), Arius concluded, must have been created. ${ }^{28}$

The Church battled with the issue for a long time. In 325, the Council of Nicaea adopted the Nicene Creed which described Christ as "God of God, Light of Light, very God of very God, begotten, not made, being of one substance with the Father." The Council affirmed that the Son and the Father are the same in essence. The creed used the term homoousios (of one substance) to define the relationship between the Father and the Son. Thus, the Arianian heresy was condemned at the Council of Nicaea.

\footnotetext{
${ }^{28}$ Jehovah Witnesses are modern-day sect which hold this view.
} 


\section{Adoptionism}

Adoptionism is the belief that Jesus was an ordinary male human being, born of Joseph and Mary, who was adopted as God's son at his baptism, resurrection or ascension. It was an attempt to explain the divine and human natures of Christ and the relationship between them. Adoptionism claims that Jesus was God's adopted Son. This thought was expressed in the Shepherd of Hermas. On adoptionism, Richard Norris writes, "The divine Logos 'became human' in the sense that he became embodied and thus shared the structural constitution of a human being." ${ }^{29}$ Adoptionism further contends that, because of Jesus' sinless life, God chose him and adopted him and united him with His Spirit.

Adoptionism was declared heresy at the end of the 2nd century and was rejected by the Synods of Antioch and the First Council of Nicaea, which defined the orthodox doctrine of the Trinity and identified Jesus with the eternally begotten Son or Word of God.

\section{Apollinarianism}

Apollinarianism is the belief that Christ had a human body, a human spirit, and the divine Logos instead of a human soul. It originated from Apollinarius (c. 310-390 AD), bishop of the church of Laodicea (in Syria) in the fourth century. Apollinarius was a strong advocate of the Nicene Creed and a friend of Athanasius. Reacting to Antiochene teachings, he formulated a doctrine that Christ had no human soul. For him, the Logos of God took the place of the human soul and performed its normal roles. The Church rejected this teaching at the Council of Constantinople, AD 381. Literature on Apollinarianism was burnt afterwards, making it difficult to have enough surviving materials on it today.

\footnotetext{
29 As cited by William Hemsworth, For The Church: Essays on Ecclesiology, Christology, and Church History (NP: Lulu.com 2017), 40.

https://books.google.com.gh/books?id=CJJGDwAAQBAJ\&pg=PA40\&lpg=PA40\&dq
} 


\section{Nestorianism}

Nestorianism emerged as the teachings of Nestorius, who became the first presbyter of Antioch and had an appointment as patriarch of Constantinople in AD 428. Nestorius' Nestorianism divided the Christ's natures as persons, thus destroying the unity and uniqueness of his body. By his teachings, people were to understand that Jesus had two persons instead of one. Obviously, this doctrine rules out any separation between Christ of faith and Christ of history.

The controversy started when Nestorius defended his presbyter who said that Mary cannot be called Mother of God (theotokos) because God could not be born..$^{30}$ Others called Mary the mother of humankind (anthropotokos). Nestorius accepted the term theotokos as orthodox but feared that Mary would be made into a goddess, and so he proposed to use the middle expression Mother of Christ or Christ-bearer (Christotokos) instead, because Christ signifies both God and human. ${ }^{31} \mathrm{He}$ found it unacceptable to think of the creature bearing the Uncreated. He feared that such a thought might lead people to think that God had a beginning of some kind.

Cyril of Alexandria (c. 375-444 AD) became the main opponent of Nestorius. When Cyril heard of Nestorius' teaching, he flew into a rage. Cyril gave sound biblical teachings concerning the person of Christ to expose the pitfalls in Nestorius' teachings. Cyril's Christological argument was fundamentally soteriological. His argument was that any being less than God cannot save humanity. Threfore if Christ is really the Savior, he must be divine. Nestorius was condemned at the Council of Ephesus in c. $431 \mathrm{AD}$ and banished to Syria and later Egypt.

\section{Euthychianism}

Euthychianism came from the Alexandrian school, precisely from

\footnotetext{
${ }^{30}$ Philip Schaff, History of the Christian Church vol. 3 (Grand Rapids, MI: Wm. B. Eerdmans Publishing Company, 1910), 717.

${ }^{31}$ Ibid.
} 
Eutyches, an abbot of Constantinople in the fifth century. Eutyches taught that Jesus' human nature got converted in the divine nature through absorption in such a way that after the union only one nature remained. Earlier, the Antiochian school had erred in dividing Christ into two separate beings or persons. In opposition to this teaching, Eutychianism elevated the personal unity of Christ over the distinction of natures. The result of intermingling the two natures as one gave rise to a third nature in which the human nature is overpowered and absorbed or transmuted into the divine. In view of this Eutychians were also called Monophysites.

\section{Conclusion}

This chapter has examined some of errors committed by early church Fathers in dealing with the personality of Christ. Most of these errors resulted from attempts to overemphasize one aspect of the person of Christ. One lesson for the reader is the need to keep a balance between the humanity and divinity of Christ, since anything less would result in unbiblical teaching. Having gone through these controversies that surrounded the person of Christ in the early centuries of the church, the reader is now better equipped to guard against falling into such heresies. The rest of this study deals with how biblical Christology is implied in the OT and fully revealed in the NT. 


\section{Review Exercise}

1. How did Christological controversies of the early church help in shaping the theology of the Church?

2. To what extent can we say that Christological heresies are present in contemporary Christianity?

3. Critically assess the strengths and weaknesses of Ebionism.

4. Explain the following:
a) Docetism
b) Nestorianism
c) Euthychianism.

Why are these doctrines unorthodox?

5. How would you use Scripture to prove that Arianism is unbiblical?

6. How did Greek philosophy affect the Christology of the early church?

7. "Christological confessions are culturally informed." Give a critical appraisal of this assertion.

8. To what extent can we say that the Father and the Son are of the same substance? Support your answer with scriptural texts. 


\section{CHAPTER 2 \\ THE OLD TESTAMENT AND CHRISTOLOGY}

The starting-point for Christological reflections is the OT, the foundation for every Christian doctrine. The concept of the Messiah is present and consistently foreshadowed in the OT. This chapter explores how the OT prepares its readers to appreciate what the NT reveals about Jesus Christ. Specifically, the chapter considers a special angel called the "angel of the LORD." Messianic prophecies and their fulfillment are considered briefly as well. The main point of this chapter is that the OT references to the angel of the LORD are pre-incarnate appearances of the Second Person of the Trinity, the Christ.

\section{The Angel of the LORD or the Angel of God}

The most mysterious and enigmatic figure in the OT is "the angel of the LORD." ${ }^{2}$ He appeared to Abraham, Hagar, Isaac, Jacob, Manoah and his wife, Moses, Joshua, and many others. The Hebrew word malak translated "angel" actually means "a messenger." As a messenger, the angel of the LORD must be a distinct person from the LORD as the sender and the sent cannot be the same person. In this section, we look at key passages dealing with the appearances of this special angel.

\section{His Appearance to Hagar}

The angel of the LORD appears first in Scripture, in Genesis 16:7, to

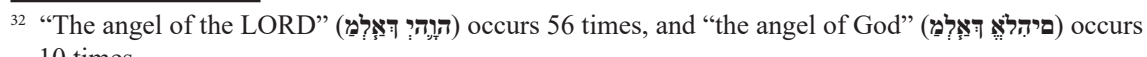
10 times. 
Hagar near a spring in the desert. He promises to multiply Hagar's descendants (v. 10). Obviously, the angel promises what only God could do. Interestingly, the author declares the angel of the LORD as LORD and Hagar says "“'You are El-roi"; for she said, "Have I really seen God and remained alive after seeing him?" (v. 13, NRSV). Hagar identified the angel with God (El-roi, the God who sees).

The angel of God again appeared to Hagar in the wilderness of Beersheba after Abraham had sent Hagar and Ishmael away (Gen. 21). Hagar feared that Ishmael would die and withdrew a short distance from him, so as not to see the death of the child, and she wept (v. 17). Here, the angel of God distinguishes between himself and God, of whom he speaks in the third person, "God has heard the voice of the lad" (v. 17). At the same time, he continues in the next verse to repeat the promise made before, saying, "I will make of him a great nation" (v. 18). The speaker here is God himself, yet a person distinct from God.

\section{His Appearance to Abraham}

The angel appears again in Genesis 18:1ff. Here, we are told, three angels appeared to Abraham in the plains of Mamre. In v. 13, one of the angels is referred to as the LORD. As the angels turned toward Sodom, the one identified as the LORD, spoke to Abraham about plans to destroy Sodom and Gomorrah because of their sin (v. 17). Throughout Abraham's intercession on behalf of the cities, the angel is addressed as LORD, a title given only to the true God. The angel speaks as the LORD, and assumes the authority of God, to pardon or punish as he sees fit.

When the execution of the sentence pronounced on Sodom is mentioned, we are told, "Then the LORD rained down burning sulfur on Sodom and Gomorrah - from the LORD out of the heavens" (Gen. 19:24). A careful reading of this text shows the LORD at Sodom as a distinct person from the LORD in heaven. The one on earth at Sodom is the angel of the LORD and the one in heaven is 
the LORD. Henry M. Morris rightly states that, "This verse seems to note that two persons of the Godhead were participating [in this divine assignment]. 'The LORD' (evidently the one manifested to Abraham) called down the judgment, but it came from 'the LORD' out of heaven." 33

In Genesis 22:2, God commands Abraham to offer up Isaac as a sacrifice. The angel of the LORD restrains him just when he was about to strike Isaac, and says, “... for now I know that you fear God, since you have not withheld your son, your only son, from me" (v.12, our emphasis). By saying that "...you have not withheld your son, your only son, from me" (not from him) the angel implied he was the one who asked that Isaac should be sacrificed to him. Apparently, if Isaac had died, he would have been sacrificed to this "angel." We know that it is God who asked Abraham to sacrifice Isaac (Gen. 22:2). So, if the angel of the LORD says Abraham has not withheld Isaac from "him" (that is, the angel), then it seems sound to conclude that he is the God who asked that Isaac be sacrificed to him.

\section{His Appearance to Jacob}

In Genesis 32:24-32, Jacob is said to have wrestled with an angel, who blessed him, and in seeing him Jacob said, "I have seen God face to face" (v. 30). He claims to be "the God of Bethel;" that is, the God who appeared to Jacob at Bethel, and to whom Jacob made a vow $(31: 13$ see also 28:12-22; 35:1). The prophet Hosea, refers to this event, where he says, "He [Jacob] struggled with the angel and overcame him; he wept and begged for his favor. He found him at Bethel and talked with him there - the LORD God Almighty, the LORD is his name!" (12:4-5). The angel, with whom Jacob wrestled, is declared by Hosea to be the LORD God Almighty.

The divinity of the angel is made certain by Jacob's statement in Genesis 48:3, 15. When Jacob was about to die, he decides to bless Joseph's sons and to adopt them as his own. Genesis 48:15

\footnotetext{
${ }^{33}$ Henry M. Morris, The Genesis Record (Grand Rapids, MI: Baker Book House, 2000), 353.
} 
reads: "Then he blessed Joseph and said, 'May the God before whom my father Abraham and Isaac walked, the God who has been my shepherd all my life to this day, the angel who has delivered me from all harm - may he bless these boys." In this benediction, he calls this angel both "God" and "the angel." In Jacob's blessing, we realize that the angel cannot be different in essence from God Almighty because the blessing of the angel is the same as that of the God who shepherded him and it is the same as that of the God of Isaac and Abraham. This is evident in the statement. "...may he bless these boys." The three nouns "God before whom..., the God who has been my shepherd... and the angel who has delivered me..." together have the pronoun "he", not "they". Philip Eveson is therefore right to point out that "The angel' is a reference, not to a heavenly messenger sent by God but to God himself seen in human form." 34 The point is that the angel is a divine person, not a created being.

\section{His Appearance to Moses}

Exodus 3:1ff gives the account of the revelation of God to Moses on Mount Horeb. The angel of the LORD appeared to him in a flame of fire out of the midst of a bush. As Moses turned to see this great sight, God called unto him, out of the bush and instructed him not to draw further closer. Furthermore, he declared, "I am the God of your father, the God of Abraham, the God of Isaac, and the God of Jacob" (v. 6). Moses then hid his face; because he was afraid to look upon God." In this passage, the angel of the LORD is identical with the LORD, and is declared to be the God of Abraham, Isaac, and Jacob.

\section{His Appearance to Israel}

The angel of the LORD appears also in Exodus 23:20 when the Israelites were on their way to Canaan. It is said, "Behold, I send an angel before you, to keep you in the way, and to bring you into the

\footnotetext{
${ }^{34}$ Philip Eveson, Book of Origins (Darlington: Evangelical Press, 2001), 555.
} 
place which I have prepared. Beware of him, and obey his voice, do not provoke him; for he will not pardon your transgressions: for my name is in him" (emphasis ours). The last phrase "my name is in him" implies "God himself as manifested." For instance, it is said during the dedication of the Temple by Solomon in 1 Kings 8:29, "My name shall be there," meaning, "There will I dwell." The personal distinction between the LORD and the angel of the LORD is clearly presented in this passage as well.

The fact that the angel of the LORD is a divine person is further manifested from the account given in Exodus 32 and 33. In punishing the idolatrous act of the people, God personally threatened to lead them no longer. In reaction to God's decision, the Israelites assembled at the entrance of the Tabernacle. It was there that the LORD descended and spoke to Moses face to face as a man speaks to his friend. And Moses interceded for the people and said, if the LORD presence will not go with the then He should carry them not up from their present location. The LORD replied and promised to let his presence go with the and finally give them rest (33:11-15). This shows that a divine person, called the angel of the LORD, had previously guided the people and that on their repentance, he promised to continue with them. This divine angel is in Isaiah 63:9, referred to as "the angel of the face of the LORD" (the angel or the messenger, who is the image of God, cf. Col. 1:15a).

Judges 2:1-2 has an interesting observation about the exodus. It reads: "The angel of the LORD went up from Gilgal to Bokim and said, 'I brought you up out of Egypt and led you into the land I swore to give to your ancestors. I said, 'I will never break my covenant with you, and you shall not make a covenant with the people of this land, but you shall break down their altars.' Yet you have disobeyed me. Why have you done this?" We know from Exodus 20:2 that it is the LORD God who brought the Israelite out from the land of Egypt. Yet, the angel of the LORD claims to be the one who delivered the Israelites from Egypt. Given the distinction in their personality (Ex. 23:30) the obvious conclusion is that two persons have each been referred to as the LORD in the present text. 


\section{His Appearance to Joshua, and to Gideon}

Later this same angel, manifested himself to Joshua (Moses' successor) as "Prince of the host of the LORD" (5:14). This special angel appeared to Gideon (Judges 6: 11-14). The writer of Judges identifies the angel as the LORD (vv. 14-16). About the conversation between the angel and Gideon, we read:

The LORD turned to him and said, "Go in the strength you have and save Israel out of Midian's hand. Am I not sending you?" "Pardon me, my lord," Gideon replied, "but how can I save Israel? My clan is the weakest in Manasseh, and I am the least in my family." The LORD answered, "I will be with you, and you will strike down all the Midianites, leaving none alive." Realizing later that he had spoken with the angel of the LORD, Gideon said, "Alas, Sovereign the LORD! I have seen the angel of the LORD face to face!" (v. 22).

Apart from the fact the angel is called the LORD, Gideon is shocked that he has spoken face to face with him. He is shocked because he regards him as God and so knows that by speaking to God face to face, he is supposed to die.

\section{His Appearance to Manoah and his Wife}

In Judges 13:13-23 the angel of the LORD talks to Manoah and his wife, and tells them to offer him a burnt offering, an offering which was to be offered only to the LORD. In v. 21, Manoah recognized him as the angel of the LORD because of his actions on the altar. Later, Manoah said "We shall surely die, because we have seen God!" Manoah asked about his name and the angel revealed his name as "too wonderful" (v. 18). This is comparable to the Messiah's name given in Isaiah 9:6. This word for wonderful in Judges 13:18 is Pil'iy, an adjective, meaning wonderful, incomprehensible or extraordinary. The word for wonderful in Isaiah 9:6 is Pel'e which is the noun form of Pil'iy. Both words are from the same root word Pala. 


\section{His Appearance in Malachi}

In Malachi 3:1 we read, "'See, I will send my messenger, who will prepare the way before me. Then suddenly the LORD you are seeking will come to his temple; the messenger of the covenant, whom you desire, will come,' says the LORD Almighty." In this verse, the one who was to come to his temple is none other than the messenger of the covenant (or the angel of the covenant), the very same angel who is referred to as the LORD. We also realize that the angel of the LORD is the one who made his covenant with the Israelite. Thus, we can say that the covenant is his covenant. That is the reason why he uses the phrase "my covenant". Therefore, he is the angel of the covenant we read about in Malachi 3:1. Granted that Malachi 3:1 predicts the first advent of the Messiah, there is no doubt that Jesus is the angel of the LORD.

\section{Who is the Angel of the LORD?}

Three schools of interpretations have emerged regarding the identity of the Angel of the LORD. The first school holds that the angel of the LORD is a created angel, one of the spirits who wait continually on God and does his will. According to this line of interpretation, the angel assumes divine titles, claims divine prerogatives, and accepts divine homage, because as a representative of God he has the right to the titles and honors of God. Hence, he speaks as God because God speaks through him.

Though this interpretation sounds good, it seems to be very unlikely given that the cases in which he is presented as given are many and the claim to be divine is explicit. Charles Hodge therefore contends that, "if the cases of the kind were few in number, and if the person designated as the angel of Yahweh did not so obviously claim to be himself Yahweh"35 then such a proposal could be acceptable. Additionally, God is not always presented in the Bible as one person

${ }^{35}$ Charles Hodge, Systematic Theology I (Massachusetts: Hendrickson Publishers, 2008), 489. 
and so the harmony of the Bible would be affected should we bend the "rules" in favor of this hypothesis. Besides, some biblical passages (such as John 12:41; Rom. 14:11; 1 Cor. 10: 4; Heb. 1:1013) implicitly attribute the angel of LORD, the manifested LORD who led the Israelites through the wilderness, and who dwelt in the temple, to Christ, the eternal Son of God, who became flesh.

The second position is that, the angel of the LORD, though divine, is not personally distinct from the LORD Himself. Thus, it was one and the same person who sent and was sent, was speaker and the one spoken to. From the logic that the sender and the sent are not the same, this hypothesis is definitely invalid.

The third school of thought argues that the angel of the LORD is pre-incarnate Christ. The angel of the LORD is thus the second person of the Trinity. In our candid opinion, this position appears to be more convincing, given the overarching theme of Scripture as promise given and later fulfilled in Christ. This theme points to the primary and fundamental revelation of the great divine truth of God's self-disclosure in the angel of the Lord, on which all the subsequent revelations of Scripture are founded. We accordingly find throughout the various OT passages which refer to a person called the angel of the LORD who, on the one hand, is identified with the LORD and on the other hand distinguished from the LORD. He accepts divine worship, claims divine authority, exercises divine prerogatives, and receives divine homage. Hodge shares this view saying:

...if in one or two instances the messenger spoke in the name of him who sent him, we might assume that the person thus designated was an ordinary angel or minister of God. But this is a pervading representation of the Bible; we find that these terms are applied, not first to one, and then to another angel indiscriminately, but to one particular angel; The person so designated is also called the Son of God, the Mighty God; the work attributed to him is elsewhere attributed to God himself. ${ }^{36}$

\footnotetext{
${ }^{36}$ Ibid.,485.
} 
The angel of the LORD was sent into the world by the LORD (Jud. 13:8-9), just as Jesus was sent into the world in NT times by the Father (John 3:17). The angel of the LORD prayed to the LORD on behalf of the people of God (Zech. 1:12), just as Jesus prays to the Father for the people of God today (Heb. 7:25; 1 John 2:1-2). Appearances of this "angel" could not be the Father or the Holy Spirit because, by their nature, the Father and the Holy Spirit are spirits that cannot be seen. The Father is one "whom no one has seen or can see" (1 Tim. 6:16, NIV; see also John 1:18, 5:37). Therefore, since all physical manifestations of God are associated with the Second Person of the Trinity, the angel of LORD who is the visible manifestation of the LORD, is the Second Person of the Triune God. For Lewis Sperry Chafer, this means "....He is one of the Godhead who serves as messenger or revealer." ${ }^{37}$ The Angel of the LORD and Jesus engaged in amazingly similar ministries - such as delivering the enslaved (Ex.3; Gal. 1:4; 1 Thess. 1:10; 2 Tim. 4:18; Heb. 2:1415 ) and comforting the downcast (Gen. 16:7-13; 1 Kings 19:4-8; Matt. 14:14, 15:32-39).

Another reason why we assert that this angel was not one of those ministering spirits sent by God to do God's will but a special appearance of LORD Himself is that, after the incarnation of Jesus Christ, the angel of the LORD appears no longer. Our conclusion on the whole issue is not strange to the NT. Like the angel, Jesus was sent by the Father (John 5:36, John 16:28), speaks for the Father (John $3: 34 ; 14: 24$ ), exercises the Father's power (Matt. 28:18), forgives sin (Matt. 9:2), and receives worship (Matt. 14:33; John 9:38). In Luke 24:27, it is said of our Lord Jesus Christ, that "beginning from Moses, and all the prophets, he expounded to them in all the Scriptures the things concerning himself."

Charles Hodge has noted that, "Abraham therefore saw the day of Christ and was glad, and as our Lord said, 'Before Abraham was I am", "proves that the person predicted as the seed of the

Lewis Sperry Chafer, Systematic Theology Vol. 1\&2, (Grand Rapids, MI: Kregel Publications, 1993), 328. 
woman and as the seed of Abraham, through whom redemption was to be effected, was to be both God and [hu]man. He could not be the seed of Abraham unless ... [hu]man, and he could not be the Saviour of men [and women] unless God." 38 In the New Testament, this manifested LORD, who led his people under the Old Testament times, is declared to be the Son of God who was manifested in the flesh. It is therefore certain that by the angel of Yahweh in the early books of Scripture, we are to understand a divine person, distinct from the Father. We conclude with Hodge's assertion that,

it can hardly be doubted, therefore, that this angel was the Son of God, sent by Him and therefore called his angel; who in Is. 63 is designated as the Saviour of Israel and the Redeemer of Jacob; who came to reveal God, as He was the brightness of his glory and the express image of his person, in whom was his name, or, as it is expressed in the New Testament, the fullness of the Godhead; who in the fullness of time, for us men [and women] and for our salvation, became flesh, and revealed his glory as the only begotten Son full of grace and truth. ${ }^{39}$

\section{Has anyone seen God before?}

The Bible declares that no one has seen or can see God (Ex. 33:20; John 1:18; 5:37; 1 Tim. 6:16; 1 John 4:12, 20) except Christ (John $6: 46)$. Yet, we have many verses in the OT which claim that people "saw God" or the angel of God, who also possesses divine attributes (Gen. 12:7; 26:2, 24; Ex. 24:9-10; Is. 6:1). The Hebrew word ra'ah translated "appeared" in most of these texts, means "a literal manifestation or appearance that was seen with the physical eye." As Robert Morey correctly notes, "It (is) not a vision within the head, but a literal appearance before the eyes...The word ha:r: is the normal Hebrew word to describe what is exposed to the eye of [hu]man[s]." 40

\footnotetext{
${ }^{38}$ Hodge, Systematic Theology I, 484-485.

${ }^{39}$ Ibid., 368.

${ }^{40}$ Robert Morey, Trinity: Evidence and Issues (Iowa Falls: World Bible Publishers Inc., 1996), np. https://books.google.com.gh/books?id=jVVLG5k5A14C\&pg=PT88\&lpg=PT88\&dq (Accessed: 12th January, 2019)
} 
The foregoing presents two contrasting facts: (1) No one has seen God before and (2) God was seen by some OT personalities. The solution to the seeming contradiction lies, first, in our recognition of the fact that when the Bible mentions God, it can refer to the Father, the Son, the Holy Spirit or the Godhead. Secondly, we must note that, two of these persons of the Godhead (the Father and the Holy Spirit), by nature, have no physical body for us to see. Only Jesus can be seen. Thus, Christ is "the image of the invisible God..." (Col 1:15), "the exact representation of his Father's being" (Heb. 1:3), whoever has seen Christ has seen the Father (John 14:9) and in him (Christ) the fullness of the deity dwell bodily (Col. 2:9). Thus, when Jesus said in John 1:18 that, "No one had seen God at any time.", he really meant "No one has seen the Father except the one who is from God; only he has seen the Father" (John 6:46, cf. 6:37).

The Logos, the Word, manifested himself sometimes in the form of the angel, sometimes as a human figure, sometimes in nature (Ex. 13:21; 20:18-22), and sometimes in an unidentified form (cf. Gen. 17:1,22; 35:9). Since the Logos is both with God and is God (John 1:1), it can both be true that (1) people in the OT saw God (the Son) and at the same time (2) no one has seen God (the Father) before. We conclude that Jesus, in his pre-incarnate form as the Word (Logos) of God, performed the role of revealing God to humankind in OT times.

\section{Messianic Prophecies and their Fulfilment in Christ}

The Jews of OT times looked forward to the coming of their Messiah, according to the prophecies they were given in their Scriptures. The Messiah was to appear in the fullness of time to bring redemption to his people, through whom the knowledge of the true religion was to be extended throughout the world. The word Messiah derives from the Hebrew participle Mashiach which means "anointed one". ${ }^{41}$ The Messiah receives his anointing from Yahweh and so he is "the ${ }^{41}$ Colin Brown (ed.), The New International Dictionary of New Testament Theology vol. 2

(Grand Rapids, MI: regency reference library, 1976), s.v. Jesus Christ. 
anointed one of Yahweh", an allusion to the rite of anointing the king (1 Sam. 9:16; 24:6). God's anointing was not reserved for kings only but also for people who were assigned special roles by God. The priest was anointed (Ex. 28:41), prophets were anointed for their office (e.g. Elisha, see 1 Kings 19:16). Of interest to the present study is the anointed one through whom God was to bless the whole world. From NT perspective, Jesus the Christ is the Messiah the OT promised. In the table below we present some key Messianic prophecies fulfilled in the life and ministry of Jesus Christ.

\section{About His Person}

\begin{tabular}{|l|l|l|}
\hline His Person & OT Prophecy & NT Fulfillment \\
\hline Name & Is. 7:14 & Matt. 1:23 \\
\hline Humanity & Is. 7:14 & Heb. 2:14 \\
\hline Divinity & Is. 9:6 & Luke 2:11 \\
\hline Davidic Kingship & 2 Sam. 7:11-16, Is. 9:7 & Luke 1:31-33 \\
\hline $\begin{array}{l}\text { Lineage/Tribe } \\
\text { of Judah }\end{array}$ & Gen. 49:8-10 & Luke 3:33; Rev. 5:5-7 \\
\hline Seed of a woman & Gen. 3:15 & Gal. 4:4 \\
\hline Seed of Abraham & Gen. 12:2-3 & Matt. 1:1 \\
\hline Seed of Isaac & Gen. 17:19 & Matt. 1:2 \\
\hline Seed of Jacob & Num. 24:17 & Matt. 1:2 \\
\hline
\end{tabular}

\section{About His Birth}

\begin{tabular}{|l|l|l|}
\hline His Birth & OT Prophecy & NT Fulfillment \\
\hline Where & Mic. 2:5 & Matt. 2:5-6 \\
\hline When & Dan. 9:24-27 & Luke 2:1-2; Gal. 4:4 \\
\hline How & Is. 7:14 & Luke 1:26-38 \\
\hline Flight to Egypt & Hos. 11:1 & Matt. 2:13-15 \\
\hline $\begin{array}{l}\text { Killing of children by } \\
\text { Herod }\end{array}$ & Jer. 31:15 & Matt. 2:17-18 \\
\hline
\end{tabular}




\section{About His Ministry}

\begin{tabular}{|l|l|l|}
\hline His Ministry & OT Prophecy & NT Fulfillment \\
\hline $\begin{array}{l}\text { Preceded by a } \\
\text { forerunner }\end{array}$ & Mal. 3:1 & Luke 7:24, 27 \\
\hline Filled with the Holy Spirit & Is. 11:1-2 & Luke 4:14-22 \\
\hline Galilean ministry & Is. 9:1-2 & Matt. 4:13-17 \\
\hline $\begin{array}{l}\text { Came to heal the } \\
\text { brokenhearted }\end{array}$ & Is. 61:1-2 & Luke 4:18-19 \\
\hline $\begin{array}{l}\text { Rejected by his own } \\
\text { the Jews) }\end{array}$ & Is. 53:3 & John 1:11 \\
\hline Light to Gentiles & Is. 60:1-3; 61:1-2 & Luke 2:25-32 \\
\hline $\begin{array}{l}\text { Saviour } \\
\text { Is. 49:6 }\end{array}$ & $\begin{array}{l}\text { Matt. 1:21; John } \\
1: 29 ; \text { Luke 19:9-10 }\end{array}$ \\
\hline $\begin{array}{l}\text { A priest after the order of } \\
\text { Melchizedek }\end{array}$ & Ps. 110:4 & Heb. 5:5-6 \\
\hline Triumphal entry & Zec. 9:9 & Mark 11:7, 9, 11 \\
\hline To die for sins & Is. 53:4-7 & 1 Pet. 2:24-25 \\
\hline To Heal & Is. 53:4 & Matt. 8:16-17 \\
\hline
\end{tabular}

\section{About His Passion and Resurrection}

\begin{tabular}{|l|l|l|}
\hline $\begin{array}{l}\text { Death, Burial and } \\
\text { Resurrection }\end{array}$ & OT Prophecy & NT Fulfillment \\
\hline To be rejected & Ps. 118:22 & Matt. 21:42-43 \\
\hline To be crucified & Ps. 22:16-18 & John 19:20 \\
\hline Death and Burial & Is. 53:9 & Matt. 27:57-60 \\
\hline Resurrection & Ps. 16:9-11 & Matt. 28:2-8 \\
\hline Betrayed by a friend & Ps. 41:9 & Luke 22:47, 48 \\
\hline Sold for thirty pieces of silver & Zech. 11:12-13 & Matt. 26:15; 27:5-7 \\
\hline Accused by false witnesses & Ps. 35:11 & Mark 14:57-58 \\
\hline Silent to accusations & Is. 53:7 & Mark 15:4, 5 \\
\hline
\end{tabular}




\begin{tabular}{|l|l|l|}
\hline Spat upon and smitten & Is. 50:6 & Matt. 26:67 \\
\hline Hated without reason & Ps. 35:19 & John 15:24, 25 \\
\hline Vicarious sacrifice & Is. 53:5 & Rom. 5:6, 8 \\
\hline Crucified with transgressors & Is. 53:12 & Mark 15:27, 28 \\
\hline Hands pierced & Zech. 12:10 & John 20:27 \\
\hline Betrayed by a friend & Ps. 41:9 & Luke 22:47, 48 \\
\hline Scorned and mocked & Ps. 22:7-8 & Luke 23:35 \\
\hline Given vinegar and gall & Ps. 69:21 & Matt. 27:34 \\
\hline Prayer for his enemies & Ps. 109:4 & Luke 23:34 \\
\hline Soldiers gambled for his coat & Ps. 22:18 & Matt. 27:35 \\
\hline No bones broken & Ps. 34:20 & John 19:32-33, 36 \\
\hline Side pierced & Zech. 12:10 & John 19:34 \\
\hline Buried with the rich & Is. 53:9 & Matt. 27:57-60 \\
\hline
\end{tabular}

\begin{tabular}{|l|l|l|}
\hline $\begin{array}{l}\text { Ascension and his Future } \\
\text { Work }\end{array}$ & OT Prophecy & NT Fulfillment \\
\hline Would rise from the dead & Ps. 16:10; 49:15 & Mark 16:6-7 \\
\hline $\begin{array}{l}\text { Would ascend to God's right } \\
\text { hand }\end{array}$ & Ps. 68:18 & Mark 16:19 \\
\hline Ascension & Is. 52:13 & Ac. 1:6-11 \\
\hline Exaltation & Ps. 110:1 & $\begin{array}{l}\text { Luke 20:42-43; } \\
\text { Phil. 2:5-11 }\end{array}$ \\
\hline Second Coming & Zech. 14:3-9 & Rev. 19:11-16 \\
\hline Eternal Kingship & Dan. 2:44 & Rev. 11:15 \\
\hline
\end{tabular}

\section{The Promised Messiah: God and Human}

There are over 300 Messianic prophecies in the OT but the focus of this book is not to cover all of them. We shall consider those which will help us get a clear picture of the identity of the Messiah predicted by the OT. The story of salvation begins in the garden of Eden after the Fall of Adam. The promise of a Messiah is first given in Genesis 
3:15, a promise usually referred to as the Protoevangelium, the first gospel proclamation. The Messiah is said to be the seed of the woman. This points to the virgin conception as well as the humanity of the Messiah. The promised Messiah is the seed of the woman (not of the man and the woman). Therefore, it is only the woman who partakes in his conception. The promised seed is expected to conquer the evil one and restore to humanity what was being forfeited through the disobedience.

Isaiah 7:14 promises a Messiah who will be called Immanuel, God with us. ${ }^{42}$ In Isaiah 9:6 we are told the Messiah "shall be called Wonderful, Counselor, The mighty God, The everlasting Father, The Prince of Peace." Names as used in Hebrew express that which they designate. According to Louis Berkhoff, "In oriental thought a name was never regarded as a mere vocable, but as an expression of the nature of the thing designated." 43 There can be no doubt that this passage is saying a human child would be born who is identified as God. The LORD who was speaking through Isaiah is different from the human child who would be called the Mighty God. The passage signifies the divine nature of the Messiah.

Isaiah 12:5-6 says, "Sing to the LoRD, for he has done glorious things; let this be known to all the world. Shout aloud and sing for joy, people of Zion, for great is the Holy One of Israel among you." Here, we are told that it is the LORD himself, the holy One of Israel, who will be in the midst of the people. This is a passage about the Messiah.

Jeremiah 23:5-6 reads, "Behold, the days are coming, says the LORD, that I will raise unto David a righteous Branch, and a king shall reign and prosper, and shall execute judgment and justice in the earth. In his days Judah shall be saved, and Israel shall dwell safely: and this is his name whereby he shall be called, the LORD our righteousness." Here, "the LORD" is the speaker and he is talking

\footnotetext{
${ }^{42}$ For discussion on why Jesus was not called Immanuel and yet he is our Immanuel, consult Isaac Boaheng, Is the Bible Really the Word of God? (Sunyani: Jonnette Secretarait, 2019).

${ }^{43}$ Louis Berkhoff, Systematic Theology (Edinburg: Banner of truth, 2000), 50.
} 
about another person who will in the future come to earth who is David's descendent, a king who will reign, prosper and will judge the earth. Yahweh then gives his name as "the LORD our righteousness." Undoubtedly, two persons are both referred to as the LORD. One of these persons is the promised Messiah who will be human and a descendant of David. Both the Father and the Messiah bear the sacred name Yahweh.

Another passage of interest is Psalm 2, a popular Messianic Psalm. In this Psalm, the divinity of the Messiah is shown by: His title "the Son of God" which suggests equality with God, his universal and absolute dominion, the command that all should kiss him, meaning all should worship him, the requirement by all to acknowledge his authority and do him homage and the fact that those who trust him become blessed.

Moving on to Psalm 22, we read of a righteous sufferer whose words Christ, upon the cross, appropriates to himself (vv. 1-19). According to this passage, the suffering of the Messiah includes spiritual separation (vv. 1-2), verbal scorn (6-8), personal solitude (9$11)$, bodily suffering (12-16) as well as personal shame (17-18). He prays for deliverance (vv. 19-21). A conclusion from that deliverance is that the subject of the Psalm must be a divine person. His sufferings render it certain, (1.) That all good people will fear and love God because he rescued this sufferer from his enemies. (2.) That provision will be made for the wants of all people. (3.) That all nations will be converted unto God. (4.) That the blessings which he secures will last forever.

Psalm 45:6-7 also reveals the identity of the Messiah of the OT. In this passage, the psalmist describes the Messiah as one who passes beyond an earthly king. He refers to him as "God" (v. 6), whose throne will last forever and ever. Interestingly, Hebrews 1:8-9 tells us that it is God the Father who is speaking and referring to the Son, the Messiah, the Christ, as God (cf. Ps 45).

In Psalm 47:7-8, we read: For God is the King of all the earth; 
sing to him a psalm of praise. God reigns over the nations; God is seated on his holy throne. We know from 1 Corinthians 15:24-25, Revelation 11:15 and 19:16 that it is the Messiah in his Second Advent who will reign over all nations and hence the one referred to as God in Psalm 47:7-8 is therefore telling us that the Messiah the God who will reign.

The next passage to examine is Psalm 72 which contains a description of an exalted king, and of the blessings of his reign. These blessings are of such a nature as to prove that the subject of the psalm must be a divine person. (1.) His kingdom is to be everlasting and universal. (2.) It secures perfect peace with God and good-will among people. (3.) All people are to be brought to submit to him through love. (4.) In him all the nations of the earth are to be blessed, i.e., as we are distinctly taught in Gal. 3:16, it is in him that all the blessings of redemption are to come upon the world. The subject of this Psalm is therefore, the Redeemer of the world whose divine nature is pointed out.

In Psalm 110:1 the psalmist, referring to the Messiah, says "The LORD says to my Lord: 'Sit at my right hand, until I make your enemies your footstool." In the expression, "The LORD says to my Lord (Adonai): Sit at my right hand. .." God who is asking David's Lord to sit on His right hand. To sit on God's right hand means to be associated with God on terms of equality in glory, authority and dominion. No angel sits at God's right hand (Heb. 1:13). Daniel L. Akin quotes House as stating, "the whole text assumes divine authority and future (both immediate and long term) perspective."44 This Psalm attests to the divine nature of the Messiah. Peter also quotes this passage in his sermon on the day of Pentecost to prove the Lordship and Messiahship of Jesus (Acts 2:34-35). This person, who is both David's Son and David's Lord, is eternally both priest and king. This again is referred to in Hebrews 7: 17, to prove that he must be a divine person. It is therefore not surprising that in Matthew 22:41-46, Jesus makes it clear that two different persons are

${ }^{44}$ Daniel L. Akin (ed.), A Theology for the Church (Tennessee: B \& H Publishing Group, 2007), 4 
referred to as God in Psalm 110: 1. Thus, the verse talks about Jesus simultaneously being David's Son and David's Lord.

The book of Daniel also gives us a clue to the identity of the Messiah. In Daniel 2:44, it is foretold that the kingdom of the Messiah will be everlasting, and is destined to supersede and absorb all other kingdoms. In 7: 9-14, it is said that one like the Son of Man was brought unto the Ancient of Days (God the Father, cf. 9-13); and dominion, glory, and kingdom given to him; that all people, nations, and languages should serve him. His dominion is to be an everlasting dominion, which shall not pass away, and his kingdom shall not be destroyed. In 9:24-27, we read the prediction of the seventy weeks, and the coming and work of the Messiah, whose work is truly divine. The title "Son of Man" is used only here in the entire OT. The sense in which it is used underscores the divinity of the Messiah.

Zechariah 2:10-11 reads, "Sing and rejoice, O daughter of Zion: for behold, I come, and I will dwell in your midst, says the LORD. And many nations shall be joined to the LORD in that day, and shall be my people, and I will dwell among you, and you shall know that the LORD of hosts has sent me to you." Here, the LORD speaks of himself as sent by the LORD of hosts. Note that the Lord who is sent will "dwell among you". Clearly two persons are referred to as LORD.

In Zechariah 12:10, Yahweh speaks prophetically of the crucifixion and the Second Advent of the Messiah with these words: "I will pour upon the house of David, and upon the inhabitants of Jerusalem, the spirit of grace and of supplications: and they shall look upon me whom they have pierced, and they shall mourn for him, as one mourns for his only son, and shall be in bitterness for him, as one who is in bitterness for his firstborn." Clearly, the LORD God is speaking, yet He himself changes the usage of "I" and "me" to "him", and he speaks about being "pierced". Since it was Christ who was pierced at his crucifixion (John 19:34), there can be no doubt that Clearly, in this text, God the Father is speaking of his beloved 
Son, the Second Person of the Trinity, the one who shares the divine nature, and the one who was to be made sin for us.

The LORD speaking about the deliverance ministry of the Messiah says, "But I will have compassion on the house of Judah and deliver them by the LORD their God, and will not deliver them by bow, sword, battle, horses, or horsemen" (Hos. 1:7). In this passage, the LORD who is speaking, promises deliverance through another LORD as the speaker refers to the one spoken about in the third person, saying "the LORD" will deliver them, as if "the LORD" were not the one speaking. Robert Morey argues, "If I as the first person promise to do something for you as the second person through a third person, am I not implying that I am not the same as the third person? If grammar means anything, the answer is, Yes. ${ }^{.45}$

Malachi 3:1 says: Behold, I will send my messenger, and he shall prepare the way before me; and the LORD, whom you seek, shall suddenly come to his temple, even the messenger of the covenant, whom you delight in: behold he shall come, said the Lord of hosts. In this verse "the LORD whom you seek", the Messiah, is different from the Lord who will send him. The messenger to prepare the way is John the Baptist. This is evident from the words of Zachariah, his father in Luke 1:76: "Yea and you, child... shall go before the face of the Lord to make ready his ways." John the Baptist prepared the way for Christ according to Isaiah 40:3, Matthew 3:3 and Mark 1:1-4. This means the one before whom John the Baptist prepared the way (Jesus Christ) is the same as "the LORD, whom you seek", the one who will suddenly come to his temple, mentioned by Malachi. Henderson, in his Commentary on Malachi 3:1, points out that the Messiah is here called "the LORD" or "the Sovereign-a title nowhere given in this form (with the article) to any but Yahweh; that he is predicted as coming to the temple as its proprietor; and that he is identified with the angel of the covenant, elsewhere shown to be one with Yahweh himself." ${ }^{46}$ The conclusion is that one LORD sends another

${ }^{45}$ Morey, The Trinity, np.

${ }^{46}$ Henderson as cited in Augustus H. Strong, Systematic Theology I (Np: Delmarva Publications, Inc., 2015), 583.https://books.google.com.gh/books?id=xlN2CgAAQBAJ\&pg=PT897\&lpg=PT897\&dq (Accessed: 4th May, 2019) 
LORD. It must be said that, the OT not only predicted the Messiah but also proclaimed him to be human and God at the same time.

\section{Jesus Christ is the LORD of the Old Testament}

The fact that Jesus Christ is the LORD can be determined by comparing the following OT verses with their corresponding NT verses. For example, Isaiah 40:3 speaks about preparing the way for the LORD. When we compare this verse with Mark 1:3 and its parallels, we see that Jesus is the LORD who had the way prepared for him by John the Baptist. Next, Joel 2:32a says that whoever calls upon the name of the LORD will be saved. In Roman 10:13 Paul says whoever calls on the name of Jesus will be saved.

Isaiah 6:1-10 records that the prophet Isaiah saw the glory of the LORD. John is his gospel says the glory that Isaiah saw was that of Jesus Christ (2:40-41). In Isaiah 44:6, 48:12 the LORD refers to Himself as "the First and the Last". In Revelation 1:8, 17, Jesus refers to himself as "the Alpha and the Omega" and "the First and the Last" $(1: 11 ; 2: 8 ; 22: 13)$.

Isaiah 45: 21-25 states that every knee shall bend before the LORD. We read in Phil. 2:10-11 that it is Jesus before whom every knee should bend. In Zechariah 12:10 the LORD is speaking and says that, "they will look on me whom they have pierced." This means Yahweh was expected to be pierced. In the NT, this prophecy is claimed for Jesus Christ (John 19:34-37; Rev. 1:7b). Indeed, he is the one who was pierced. More so, in Isaiah 8:13,14 we are told the LORD Almighty will be a stone that causes people to stumble and a rock that makes them fall. Jesus Christ according to 1 Peter 2:7,8 is this rock.

The OT reveals Yahweh as the righteous God and Savior (Isa. 43:3; 45:21-22; Ezek. 34:22). In the NT, Jesus is presented as the Savior of the world (Acts 4:11,12; 1 John 4:14). Again, In Proverbs 16:4 we are told "The LORD has made all things for himself" (Prov. 
16:4). In Colossians 1:16 Paul says all things were made for Christ.

About the LORD of the OT, we are told, "In the beginning you laid the foundations of the earth, and the heavens are the work of your hands. They will perish, but you remain; they will all wear out like a garment. Like clothing you will change them and they will be discarded. But you remain the same, and your years will never end" (Psa. 102:24-27). The writer of Hebrews applies this passage to Jesus Christ in Heb. 1:8,10-12.

The LORD is an everlasting king (Ex. 15:18) and LORD of lords (Deut.10:17; Ps. 136:3), and Jesus is King of kings and Lord of lords (Rev. 19:11-16). In addition, only God has the right and power to forgive sins (Jer. 31:34; Ps.130:4). Jesus Christ claims this right for himself (Matt. 9:2-3). Further, the OT says only God is the giver of life (1 Sam. 2:6; Deut. 32:39) and can raise people from the dead (Ps. 2:7). Yet, in the NT, we are told Jesus also gives life (John 5:21).

Moreover, in Isaiah 42:8 the LORD vowed not to share his glory with anyone (see also Isa. 48:11). Yet, Paul describes Jesus as the owner of glory in his words, "For had they (the leaders) known it, they would not have crucified the Lord of Glory" (1 Cor. 2:8). Also, Jesus claims to have eternal glory (John 17:5).

The Scriptures teach us that there is only one God and we are commanded that we should worship no other (Exod. 20:3). Yet in the NT, Jesus Christ is worshipped eternally (Phil. 2:10-11; Rev. 5:9-14).

In the OT, the LORD is depicted as the bridegroom (Isa. 62:5; Hos. 2:16). In the NT Christ is presented as the bridegroom (Mark 2:19; Matt. 25:1-13; Rev. 21:2). Also, the LORD is referred to as the Rock of Israel (1 Sam. 2.2; Ps. 22.2-3; 92.15-93:2; 95:1). Paul in 1 Corinthians 10:4 interprets the 'rock' of Ex. 17:6 as referring to Christ (see also 1 Pet. 2:6-8).

The LORD is described as Shepherd (Ps. 23:1; Ezek. 34:15). Jesus said, "I am the Good Shepherd" (John 10:11). "I am a Good Shepherd" would have meant he is one of the many Good Shepherds. 
Peter calls him "The Shepherd and guardian of your souls" (1 Pet. 2:25) and again "the chief Shepherd" (1 Pet. 5:4). Hebrews describes him as "the great shepherd" (Heb. 13:20). That the title is unique is clear from John 10:16 "So there shall be one flock, one shepherd." Further still, the LORD is Judge in the OT (Gen. 18:25; Joel 3:12). In the NT, Jesus Christ is presented as judge (Matt. 25:31-46 and John 5:27ff; Acts 10: 42; Rom. 2:3; 2 Tim. 4:1; 2 Cor. 5:10).

More so, the LORD is described as light (Isa. 60:19; Ps. 27:1). The coming Messiah is designated in two familiar prophecies as "Light" (Isa. 9:2, cf. Matt. 4:16; and Isa. 49:6, cf. Luke 2:32). Six times in John's gospel (vv. 1:4, 1:5, 1:7, 1:8, 1:9, 8:12) this term is used to describe Jesus. His uniqueness is stressed in v. 9: "The true light". Jesus himself gave this testimony: "I am the light of the world" (John 8:12). If we assume the traditional view that the author ${ }^{47}$ of John's gospel also wrote the first epistle of John, then we can come to the conclusion that the same author, who described Jesus as the true light (John 1:9a), also wrote in 1 John 1:5, "God is light and in him is no darkness at all."

Finally, we know from the OT that God is creator in the OT (Gen. 1:1). In Isa. 40:28 Yahweh is referred to as "the eternal God, the creator of the ends of the earth" (cf. Jer. 10:16). John, Paul and the writer of Hebrews refer to Jesus as creator (John 1:3; Col. 1:16; Heb. 1: 8-10).

\section{Conclusion}

This chapter has given a foundation on which to build our Christological thinking. Contrary to the view that Christ began in the NT, we have given evidence of many pre-incarnate appearances of pre-incarnate Christ to various people in the OT. We also examined various prophecies Jesus Christ fulfills that reveal him as the Messiah.

\footnotetext{
${ }^{47}$ We acknowledge the complex debate among scholars over the authorship of John's gospel, I, II \& III John and Revelation. While it is difficult to assert that the same author wrote all the four books, it is less controversial to suggest that the four books come from the "Johannine Community" with the apostle John being the main authority behind the various canonised writings within the corpus.
} 
In the chapters that follow, we will build upon the foundation laid and then explore Christology further according to the perspective of the NT.

\section{Review Exercise}

1. In your opinion, what is the identity of the angel of the LORD in the OT?

2. Are there any basis for biblical Christology in the OT? Explain your answer.

3. What kind of Messiah does the OT predict?

4. How does Jesus Christ fulfill OT Messianic prophecies?

5. Discuss the assertion that "the OT promised that God will come in human flesh." 


\section{CHAPTER 3 \\ LOGOS CHRISTOLOGY (JOHN 1:1)}

This chapter and subsequent ones build on OT foundation of Christology which the previous chapter discussed. Our focus in this chapter is the contribution of the first verse of John's gospel to Christology, especially the divinity of Christ. We do so by considering the text within the context of John's prologue $(1: 1-18)$, closely linking it with 1:14 which marks the movement of "the logos" from its pre-incarnate state $(1: 1)$ to the point of incarnation. ${ }^{48}$ The main theological message highlighted in the chapter (based on exegesis of the text under consideration) is John's affirmation of the Word (Christ) as "being coequal, coeternal, coexistent, and consubstantial with the Father." 49

\section{Historical Context of the Fourth Gospel}

The NT contains writings which were in circulation in the late $90 \mathrm{CEs}$, which found their way into the canon under the belief that Apostle John was the authority behind all of them. These books, which are known for their similarities in phraseology and styles of writing, are the gospel according to John, 1, 2 and 3 John and the book of Revelation. There also differences among them. Though the gospel of John is anonymous, in that it does not name its author, Christian tradition attributes it to John the apostle. One reference of the gospel reads, "This is the disciple who bears witness to these things, and wrote these things, and we know that his witness is true" (21:24). Apparently, the most natural antecedent to the relative pronoun, "this",

\footnotetext{
${ }^{48}$ Later in this book we shall deal fully with John 1:14 as a Christological text.

${ }^{49}$ Akin (ed.), A Theology for the Church, 494.
} 
is the "disciple whom Jesus loved" (21:20). This disciple is identified as John. Yet, the identity of the beloved disciple is quite obscure in the gospel. For our purposes, we shall simply keep to the position of the early church (the traditional view) with the understanding that John is the authority behind the entire Johannine corpus.

The date for the composition of the fourth gospel is debatable. Having surveyed the debate, we find, as convincing, the argument that the gospel was written in Ephesus between AD 85-95. Christians, due to persecution, had fled into Asia Minor (c. 68-70 AD) but were now undergoing the beginnings of more severe persecution under the Emperor Domitian (c. 81-96 AD), perhaps being the worst ever seen in Church history (2 John 1-8; 3 John 9-10; Rev. 1:9; 2:9-13; 13:7-10). As a result, the national aspirations of Israel had been destroyed, the Jewish and Christian communities had been increasingly polarized. There was a rather serious disorientation prevalent among the Jews in coming to terms with their Jewish faith without the Temple. It was also the time that first generation Christians were dying out to be replaced by a new generation. Thus, John served as instructions and doctrine for a new generation of church leadership who were not eyewitnesses.

The key to the purpose of the fourth gospel is found in $20: 31-$ "These are written that you may believe that Jesus is the Christ, the Son of God, and that by believing you may have life in his name." Scholars debate as to whether this means saving faith on the part of non-Christians or growing faith on the part of Christians. While some scholars such as Leon Morris and D. A. Carson are of the view that John wrote primarily to evangelize Jews, others (Raymond E. Brown being a key example) believe that he wrote mainly for believers. ${ }^{50}$ As an Evangelist and preacher, the author of John's gospel probably wrote both to evangelize the lost and to firm up the faith of Jewish Christians who were facing persecution. ${ }^{51}$ The offer of life in fullness (John 10:10) that John's Jesus brings is both is both a present reality

50 Grant Osborne, Cornerstone Biblical Commentary (Volume 13): The Gospel of John (Illinois: Tyndale House Publishers, Inc., 2007), 6. (pdf)

${ }^{51}$ George Arthur Buttrick (ed.), The interpreter's Bible Vol. 8 (New York: Abingdon Press, 1956$), 437$. 
and a future blessing. The purpose of the gospel was to lead people to faith in Christ and hence receive eternal life. ${ }^{52}$

The fourth gospel has a unique character from the synoptic gospels. The events it captures and the arrangement of materials are different from those of the synoptic gospels. While Matthew opens with Jesus' genealogy, Mark with the ministry of John the Baptist and Luke with the dedication of his letter to Theophilus followed by the prophecy about the birth of John the Baptist, John opens his gospel with a theological prologue. The prologue is "an overture in which the motifs" 53 - life (v. 4), light (v. 4), darkness (v. 5), witness (v. 7), true (v. 9), glory (v. 14), and truth (v. 14) — " "are heard that recur again and again in the Gospel." 54 The overriding theme is "the Logos, pre-existent, incarnate, rejected, yet revealer of God and giver of sonship to those who believe in his divine mission." 55 The prologue can easily be put into stanzas with interrupting prose comments about John the Baptist (vv. 6-8, 15). G. R. Beasley-Murray rightly observes that, "from a literary viewpoint, it is a closely-knit composition, constructed with consummate artistry." 56 Within the prologue, we find the movement of "the logos" from the pre-incarnate state (1:1) to the point of incarnation (v. 14). Carson asserts that, "The Prologue summarizes how the 'Word' which was with God in the very beginning came into the sphere of time, history, tangibility." 57

Introducing John's prologue is a verse which is unparalleled in its theological value. In a real sense, this verse serves as both the basis of all that follows in the gospel and foundational pillar upon which the Christian faith is built. The Greek text of this verse consists of three separate parts (see below), each part forming a clause with a subject, a verb, and a predicate. Each clause has the same subject ("the Word"), the same verb ("was") but different predicate and

\footnotetext{
${ }^{52}$ Leon Morris, The Gospel According to John the English Text with Introduction, Exposition and Notes (Grand Rapids, Michigan: B. Eerdmans Publishing Co., 1989), 41.

${ }^{53}$ Buttrick (ed.), The interpreter's Bible Vol. 8, 463.

${ }^{54}$ Ibid.

${ }^{55}$ Ibid.

${ }^{56}$ G. R. Beasley-Murray, Word Biblical Commentary: John (vol. 36) (Waco, TX: Word Books, 1987), 4.

57 D. A. Carson, The Gospel According to John (Grand Rapids, MI: William B. Eerdmans, 1991), 111.
} 
reveals a distinct truth about the same subject. These truths (as we shall discover later) are the eternity of the Word, the relationship between the Word and God, and the essence of the Word.

The gospel writers accounted for Jesus' life and ministry from different perspectives based on the audiences and issues that each writer needed to address. The first three gospels, Matthew, Mark and Luke, accounted for Jesus' ministry and life from common perspectives. Scholars refer to these three gospels as the Synoptics because one can set them side by side in parallel and find that large sections overlap. The Synoptic gospels see the whole together in that they present different perspectives of a single story in unique ways. Scholars refer to John as the fourth gospel. The differences between John and the Synoptics are more remarkable than their similarities. John does not contain Jesus' genealogy, birth, baptism, temptation, casting out of demons, parables, transfiguration etc., which are major events in the Synoptics.

John presents a Christology from above, taking the reader further back into eternity when the Logos co-existed with the Father and possessed the Father's nature as well (1:1). ${ }^{58}$ John reverses his story in that he makes it clear that Jesus, the same person who existed in heaven before the creation of the world, descended and dwelt among us in the human life of Jesus, and ascended again. The descent and the ascent of the redeemer figure of John's incarnational Christology is implied by the assertion, "No one has ascended into heaven except the one who descended from heaven, the Son of Man" (3:13). Language like this, drawn from Jewish traditions about the figure of Wisdom, is found in the epistles, as for example in Colossians 1:1520 and Hebrews 1:1-3. For a Christology from above, as in the case of John, the incarnation was a very crucial subject. Christology from above was a common ancient method for studying Christology. ${ }^{59}$ John might therefore have been familiar with this method of Christology which he applies perfectly in his gospel. John's method influenced

\footnotetext{
${ }^{58}$ The event in John 1:1 comes first when the Bible is arranged chronologically.

${ }^{59}$ Pannenberg, Jesus-God and Man, 33.
} 
the Christology of the early church, especially Alexandrian church Fathers. ${ }^{60}$

\section{Literary Context of the Text}

The fourth gospel climaxes NT Christology. ${ }^{61}$ A careful study of the fourth gospel shows that John could have known Mark. This is sufficiently proved by a reproduction, which cannot be accidental, of the number of the out-of-the way phrases of Mark. ${ }^{62}$ More importantly, we can see that where there is verbal variation between the Synoptics, John usually agrees with Mark as against Matthew and Luke. These similarities do not, however, warrant the belief that John intended to expand Mark's work.

The literary outlook of the fourth gospel can be structured into four: (a) a Prologue (1:1-18) basically deals with the Logos hymn, which comprises the Word with God; believers become children of God; the Word becomes flesh; the Son reveals the Father, (b) "The Book of Signs" (1:19-12:50) comprising, wedding at Cana; Temple cleansing; dialogue with Nicodemus; royal official's son; meeting with Samaritan woman at the well; healing at the pool of Bethesda; feeding of 5000 and bread of life discourse; conflicts in Jerusalem; man born blind and good shepherd discourse; raising dead Lazarus back to life; anointing at Bethany; plots to kill Jesus; etc., (c) "The Book of Glory" (13:1-20:31) comprising Last Supper: washing the disciples' feet, foretelling Judas' betrayal and Peter's denial, farewell discourses; Jesus' great prayer; passion narrative: arrest, trials, crucifixion, death and burial; post-resurrection appearances to Mary Magdalene and Thomas, and (d) Epilogue (21:1-25), basically made of another post-resurrection appearance at the Sea of Tiberias/Galilee.

The text under study is at the heart of John's prologue, that covers the first 18 verses of the fourth gospel. Raymond E. Brown 60 Ibid.

${ }^{61}$ Emmanuel Asante, Jesus the Christ: A Survey of the Christological Quest (Kumasi: Wilas Press Ltd, 2009), 55.

${ }^{62}$ We can compare, e.g., Jn. 6:7 with Mk. 6:37, Jn. 12:3 and Mk. 14:3 and Mk. 14:54. 
considers the prologue as a hymn and places v. 14 in the fourth strophe. ${ }^{63}$ The prologue characterized by motifs of life (v. 4), light (v. 4), darkness (v. 5), witness (v. 7), true (v. 9), glory (v. 14), and truth (v. 14) ${ }^{64}$ pivoted around the central theme, "the Logos, pre-existent, incarnate, rejected, yet revealer of God" 65 , the one who makes people children of God when they believe in his divine mission.

Emmanuel Asante observes that John's prologue is "the most penetrating description of the career of Jesus Christ that has been written." gospel centers on Christology, for eternal life depends on the right relationship with Christ. ${ }^{67}$ John's interest in Christology is evident in this statement: "That [people] may believe that Jesus is the Christ, the Son of God, and that by believing they may have life in his name" (20:31). The identity of the Logos is not explicitly known until John reaches v. 14, where the Logos is identified as Christ. In verses 1-3, John speaks of the relationship of the Logos to God, but in verse 14, he examines the Logos 'relationship to the world.

\section{Logos in Jewish Thought}

The Hebrew equivalence for logos is $d \bar{a} b \bar{a} r$ which has the characters of both power and activity. It was used to depict communication from God to humanity (God's people). Dābār is the means of creation and is additionally understood as the word of salvation that will achieve the promise. It is also understood as the word of law, the covenant commandment. The word of God, denoting prophetic revelation, is seen in both the early prophets (Samuel, Elijah, Elisha) and the later ones (Amos, Hosea, Ezekiel, Jeremiah, and Deutero-Isaiah). In the OT, the manifested Yahweh is sometimes referred to as the Word of

\footnotetext{
${ }^{63}$ Raymond E. Brown, “The Gospel According to John (i-xii): Introduction, Translation and Notes" in The Anchor Bible, (New York: Doubledy \& Company, Inc, 1966), 4.

${ }^{64}$ Buttrick (ed.), The Interpreter's Bible vol. 8, 463.

${ }^{65}$ Ibid.

66 Asante, Jesus the Christ, 55.

${ }^{67}$ George Eldon Ladd, A Theology of the New Testament (Grand Rapids, MI: W. B. Eerdmans Publishing Company, 2001), 237.
} 
God, and to him individual subsistence and divine perfections are ascribed (see Ps. 33: 6; 119:89; Is. 40: 8; Ps. 107:20; 147:18). Bruce summarizes, "The 'Word of God' in the OT denotes God in action, especially in creation, revelation, and deliverance." ${ }^{96}$

\section{Logos in Greek Thought}

The word logos occurred in the earliest period of Greek philosophy in the works of Heraclitus who used it in the sense of "didactic discourse," "word," and even "reputation" as well as "proportion," "meaning," "universal law," and "truth." ${ }^{69} \mathrm{He}$ also used it to signify the principle which gives shape, form, or life to the material universe. In Stoicism, it refers to the cosmic law which rules the universe and at the same time is present in the human intellect. It is the unifying principle of the universe. Greeks who held to a theistic view of the universe considered logos as the means by which God reveals himself to the world. Among Greeks who had pantheistic view of the universe, $\log o s$ was used to designate the principle that held the world together and at the same time endowed people with the wisdom for living or "the animating life force or 'world soul' that permeated all the universe." one, in which each area has its own ordering laws that humans are capable of understanding." 71 Therefore, the term logos in Greek philosophy is an abstraction, not a hypostasis, and has nothing to do with incarnation.

Philo, a Jewish philosopher, regarded God as the absolute Being, "that which is" and "the One and the All." For Philo, "God alone exists for himself, without multiplicity and without mixture...

\footnotetext{
${ }^{68}$ Bruce, The Gospel According to John, 29.

${ }^{69}$ Verlyn D. Verbrugge, The NTV Theological Dictionary of New Testament Words, An Abridgment of New International Dictionary of New Testament Theology (Grand Rapids, MI: Zondervan Publishing House, 2000), 759.

${ }^{70}$ Craig L. Blomberg, Jesus and the Gospels (Tennessee: Broadman and Holman Publishers, 1997), 162.

${ }^{71}$ W. Randolph Tate, Handbook for Biblical Interpretation 2nd ed. (Grand Rapids, Michigan: Baker Academic, 2012), 244.
} 
He simply is. Hence, in His nature, He is unknowable." ${ }^{\prime 2}$ In addition, Philo taught that since God is a perfect Being, he "could not come into direct contact with the corruptible world and so He could not have directly created the world in His direct agency." ${ }^{73}$ Consequently, there was the need for a mediating principle between God and matter. This mediating principle he called the divine Reason, the logos, "in whom are comprised all the ideas of finite things, and who created the sensible world by causing these ideas to penetrate into matter." 74 The logos was both the immanent reason of God, containing within itself the world-ideal, which, while not outwardly existing, is like the immanent reason in humans and the outspoken word, proceeding from God and manifest in the world. Philo personified logos as High Priest that set the soul of humans before God, or the bridge between humans and God, or the tiller by which the Pilot of the universe steers all things.

\section{Close Reading of John 1:1}

In what follows we attempt an exegesis of John 1:1.

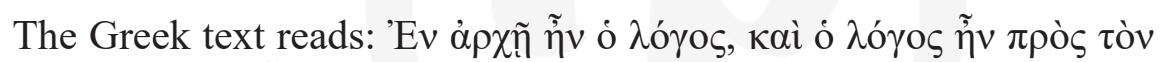

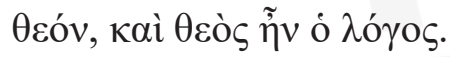

Its transliteration is: En archè èn ho logos, kai ho logos èn pros ton theon, kai theos èn ho logos.

The translation is: In [the] beginning was the Word, and the Word was with God, and the Word was God.

\section{The First Clause: En archē ēn ho logos}

$E n$ archē: The Greek word En is a preposition, which means (of place) "in", "at", "among", "with", (of time) "during", "while", (casual) "by means of", "because of." Generally, it indicates state or place,

\footnotetext{
${ }^{72}$ Vincent, Word Studies vol. 2, 29.

${ }^{73}$ Ibid.

${ }^{74}$ Ibid.
} 
and not motion, and in this instance, used with a stative verb, it is not transitive. John's use of en instead of apo indicates that he was describing the Word's status at the beginning and not that the Word existed from the beginning.

The word arche is a dative feminine singular noun referring to "a beginning", "origin"75 "first place," "ruler", "head", "chief" etc. Archē combines with episkopos (bishop or overseer) to form the word translated archbishop, meaning chief bishop or chief overseer. It is apparent from this example that arche carries the idea of "foundation" or "headship." However, in the context of John 1:1, the expression en arche is generally rendered "In the beginning." This expression is perhaps a conscious reminiscence of the opening verse of the Bible, because the OT also opens with the phrase "In the beginning" (Gen. 1:1). ${ }^{76}$ According to Carson, the meaning in both verses is: "the beginning of all things" or "the beginning of the universe." 77 By this expression, John carries our thoughts beyond the beginning of creation in time to a timeless eternity.

The word $\bar{e} n$ is an imperfect indicative active 3rd person singular verb of the root verb eimi (to be), which is used three times in this verse and translated "was" in each case, even though it could be translated "had been." There are two ways of rendering Greek verbs in the past tense - the imperfect tense and the aorist tense. William Mounce defines the two tenses as follows: "The imperfect tense describes a continuous action usually occurring in the past, while the aorist ... describes an undefined action usually occurring in the past." 78 Therefore, as an imperfect tense, èn signifies a continuous existence in the past. Rather than connoting any idea of origin for God or for the WWord, it connotes continuous existence, relationship, and predication. ${ }^{79}$ The first part, "in the beginning", does not seem too

\footnotetext{
${ }^{75}$ W.E Vine, Expository Dictionary of New Testament Words vol. I (New Jersey: Fleming H. Revell Company, 1966), 111.

${ }^{76}$ Leon Morris, The Gospel to John (Michigan: WM. B. Eerdmans Publishing Co., 1971), 72.

77 Carson, The Gospel According to John, 114.

${ }^{78}$ William D. Mounce, Basics of Biblical Greek 2nd Edition (Grand Rapids: Zondervan, 2003), 181.

79 Andreas J. Kostenberger, John: Baker Exegetical Commentary on the New Testament (Grand Rapids, MI: Baker Academic, 2004), 27.
} 
significant unless it is studied in relation to the verb ēn ("was"). The literal rendering is "When the beginning began, the Word was already there." That is, before the beginning began, the Word already existed. If John had wanted to describe the origin of the Word, he would have substituted the verb egeneto or genesthai for èn. In verse 14, the aorist form of ginomai, egeneto is used in the expression, "The Word became [egeneto] flesh". This refers to the Word becoming something that he was not. Clearly, in verses 1 and 14, John contrasts what the Word had always been with what he became at the incarnation.

The next expression is ho logos. The Greek word ho is nominative masculine singular definite article, meaning "the." The use of ho signifies that the Word is not merely a concept of God among many others but rather, he is the concept of God, the only true one, the unique one. The term logos, a nominative masculine singular noun, plays a very key role in our study. Etymologically, logos comes from legō, meaning "to lay", "pick out", "gather", "pick up"; that is, "to gather" or "put words together", and so, "to speak". ${ }^{80}$ Logos could mean "word," "speech," "matter," "thing," "command," "message," "account," "reckoning," "settlement," "respect," "reason," and so on. ${ }^{81}$ It has both Greek and Jewish backgrounds as examined above.

\section{Logos in John's Gospel}

The term やlogos las applied to Christ appears only in John 1:1, 14 and Revelation 19:13 and 1 John 1:1. John's logos is personal not a principle. He is "the real, personal God (John 1:1), the Word, who 'was' originally before the creation with God, and 'was' God, one in essence and nature," 82 and "yet personally distinct (John 1:1,18); the revealer and interpreter of the hidden being of God; the reflection and visible image of God, and the organ of all His manifestations to

\footnotetext{
${ }^{80}$ Marvin Vincent, Word Studies in the New Testament, vol. 2 (Massachusetts: Hendrickson Publishers, 2009), 25.

${ }^{81}$ William F. Arndt and F. Wilbur Gingrich, A Greek-English Lexicon of the New Testament and other Early Christian Literature (Chicago: The University of Chicago Press, 1957), 478-80.

${ }^{82}$ Vincent, Word Studies Vol. 2, 32.
} 
the world." 83

Clearly, John gives this well-known term "a new meaning." At any rate John's perspective is that of the OT and Hebraic. It is neither that of the Stoics nor even of Philo who uses the term 『logos, but John's conception of personal pre-existence. As Akin notes, "Philo's logos was a principle and an 'it", while "John's logos is 'the Word' and a "He." 84 The term logos does not explain Jesus; Jesus rather explains logos and gives $\log o s$ a new meaning. ${ }^{85}$ Like the Greek conception of human's inability to reach logos, John's logos came down and dwelt among us because we could not reach him ourselves. Walls notes, "It is not accidental that both the gospel and Christ who is its subject are called 'the Word.' But the use of '[1]ogos' in the contemporary Hellenistic world made it a useful 'bride word.",86 After a careful analysis, Akin concludes, "John's use of logos is an example of cross-cultural communication of the gospel at its best." 87 That is, the use of the word logos, offers John the opportunity to communicate multiple cultures, both Jewish and Hellenistic.

\section{The Second Clause: kai ho logos ēn pros ton theon}

The preposition pros, could mean "for," "toward," "so that," "against," "to," and "with." 88 Vincent is of the view that, "The preposition pros", which, with the accusative case, denotes motion toward, or direction, is also often used in the NT in the sense of with; and that not merely as 'being near or beside,' but as a living union and communion; implying the active notion of conversation." ${ }^{9}$ Thus, with the accusative, pros presents a plane of equality and intimacy, face-to-face with each other. This preposition often conveys the idea of reciprocity. The Word was not merely in the presence of God,

\footnotetext{
83 Ibid.

84 Akin (ed.), A Theology for the Church, 493.

${ }^{85}$ Ibid.

${ }^{86}$ Ibid.

${ }^{87}$ Ibid.

${ }^{88}$ Daniel B. Wallace, Greek Grammar Beyond the Basics (Grand Rapids, MI: Zondervan, 1996), 380.

${ }^{89}$ Vincent, Word Studies Vol. 2, 34.
} 
but there existed a mutual and reciprocal relationship between the Word and God. Literally the phrase could be rendered "the Word was face-to-face with God", an expression that points to the fellowship between the Word and God; God and the Word were together.

If John wanted to merely describe the Word's concurrent presence with God, he could have used the preposition para. Para with the dative case indicates proximity of place, specifically being alongside of, or next to something or someone. The second clause would have been rendered: "the Word was [there] with God." For an expression of a mere relational aspect between the Word and God, he would have used meta in a genitive construction (to indicate "close association") or syn with the dative construction (to indicate "intimate personal union") in which case the clause would have been rendered "and the Word was together with God."

He consciously used pros to indicate both accompaniment and relationship. John MacArthur, quotes W. Robert Cook as saying, pros "[gives] the picture of two personal beings facing [each] other and engaging in intelligent discourse. ${ }^{90}$ Pros, when used of persons, signifies an intimate personal fellowship between persons rather than being near or beside each other. The point then is that the Word was both physically present with God and relationally inclined toward God. What this means is that, in $1: 1 \mathrm{~b}$, pros expresses the inseparable communion and loving intercourse that the Word shared with the Father-before time. Paul used the same word in 2 Corinthians 5:8 to describe the intimate and special relationship that Christians will experience with Christ after death. And in 1 Corinthians 13:12, the triple use of pros (prosōpon pros prosōpon) is rendered face-to-face.

\section{The Third Clause: kai theos ēn ho logos}

Three possibilities exist for the use of the noun theos in the clause under consideration. We deem it appropriate to analyze each of these ${ }_{90}$ W. Robert Cook as cited by John MacArthur, MacArthur New Testament Commentary: John 1-11,
(Chicago: Moody Publishers, 2006), 17. 
options namely definite use, indefinite use and qualitative use. First of all, if the noun theos is taken as indefinite, we would translate it " $a$ god" (as in the New World Translation (NWT) of the Yahweh Witnesses (JWs) render it). Advocates of this position (especially the JWs) argue that the definite article, ho, does not occur before the Greek word for God, theos, and so it must be translated, "a god."

In our view, such a translation implies some form of polytheism, perhaps suggesting that the Word was merely a secondary god in a pantheon of deities. The monotheism of Orthodox Christianity will not permit this kind of idea. Besides, we see evident inconsistency in the JWs' application of their said rule that the omission of the definite article ho before the word theos makes it indefinite. Out of the 282 occurrences of theos without the definite article in the NT, it is only at sixteen places that the NWT translators are faithful to their translation principle and thus translate theos as "a god", "god", or "godly". Even in John's prologue, they are inconsistent with their own rule. Wayne A. Grudem observes as follows:

The inconsistency of the JWs' position can ... be seen in their translation of the rest of the chapter. For various reasons the word theos also lacks the definite article at other places in this chapter, such as verse 6 (there was a man sent from God), verse 12 (power to become children of God), verse 13 (but of God), and verse 18 (no one has ever seen God). If JWs were consistent with their argument about the absence of the definite article, they would have to translate all of these with the phrase "a god", but they translate it as "God" in every case. $^{91}$

From the above analysis, it becomes apparent that to render theos in John 1:1c as "a god" on the grounds that it lacks the article is too simplistic.

Secondly, theos may be taken as definite, and then give us "and the Word was [the] God." In that case, John would have 91 Wayne A. Grudem, Systematic Theology: Introduction to Christian Doctrine

(Nottingham: Inter-Varsity Press, 2011), 235. 
contradicted his previous clause in which he distinguishes between the personalities of the Word and God. To avoid contradiction, John 1:1b stated that "the Word was with God"; "God" being the translation of the articular ton theon, which is definite in semantic force by virtue of the article. In this case, such a proposition will be illogical because "ho theos" in John 1:1c, would have to be the same God as the "ton theos" of John 1:1b, and that would result in a convertible proposition logically equal to "The Word was the Father" or "The Father was the Word." 92 Such a proposition would mean that "The Word (The Father) became flesh." (John 1:14) Clearly this cannot hold water.

The third option is the qualitative use which means John intends to say that the Word and God have the same quality. This view is by far the most likely intention of John's use of theos in the clause under discussion. According to Robertson the lack of the article before theos was intended by John to distinguish the subject ho logos, from the noun complement theos so as to describe the personal nature of the Word. ${ }^{93}$ The use of the word sarx in verse 14 throws further light on this point. Here, the noun "flesh" in the phrase "The Word became flesh," - not "the flesh" (definite), or "a flesh" (indefinite), but "flesh" (qualitative) — refers not to definiteness or indefiniteness but to the Word's new nature (its new quality). Bruce's comments on this passage are valuable:

The structure of the third clause in verse 1, theos en ho logos, demands the translation "The Word was God." Since logos has the article preceding it, it is marked out as the subject. The fact that theos is the first word after the conjunction kai (and) shows that the main emphasis of the clause lies on it. Had theos as well as logos been preceded by the article the meaning would have been that the Word was completely

\footnotetext{
${ }^{92}$ See Kenneth J. Baumgarten, A Critique of the New World Translation of the Christian Greek Scriptures' Treatment of Nine Texts Employing $\Theta \varepsilon o ́ \sigma$ in Reference to Jesus Christ (Unpublished Master's Degree Thesis, South African Theological Seminary, 2007), 29.

93 A. T. Robertson, A Grammar of the Greek New Testament in the Light of Historical Research (Nashville, TN: Broadman Press, 1934), 767.
} 
identical with God, which is impossible if the Word was also "with God". What is meant is that the Word shared the nature and being of God, or (to use a piece of modern jargon) was an extension of the personality of God. ${ }^{94}$

The sentence John uses is a type of equational sentence in Greek $(\mathrm{A}=\mathrm{B})$ in which the subject is distinguished from the predicate by making the former definite and the latter indefinite. The word theos without the definite article serves as the predicate and logos with the definite article is the subject. "God" is therefore used as an adjective. By this sentence structure, John is not saying that "the Word" was God the Father, but that the same divine predication can be made of "the Word" as can be made of God the Father, and so "the Word" can be spoken of as God in the same sense.

Had John qualified theos in 1:1c with the definite article ho, he would have taught the concept of Modalism. The literal rendering of ho theos en ho logos is "the God was the Word" or "what the God was, the Word was", making theos definite. That, in this case the passage would have indicated that "God" in 1:1b (the Father) is the same person as "God" in 1:1c (the Word). Keddie, after describing the NWT as "spurious", quotes Shedd as saying that the absence of an article in connection with theos "converts the word into the abstract, denoting the species 'deity"'. 95

\section{Christology of John 1:1}

\section{Christ is pre-existent and eternal}

By saying "In the beginning was the Word" (1:1a), the evangelist makes it clear that the Word did not come into existence in time but had been in existence before time began. The most obvious message carried by this assertion is that Christ has no beginning and no end. This means that his existence is without succession. His being never

${ }_{94}$ F. F. Bruce, The Gospel of John (Grand Rapids: Wm. B. Eerdmans, 1983), 31.

${ }_{95}$ Gordon J. Keddie, An EP Study Commentary on John Volume 1, (Auburn: Evangelical Press, 2001), 33. 
had a beginning, for had there ever been a time when Christ was not, nothing could ever have existed (because he is the one who sustains all things, Col. 1:17). For this reason, he can be described as "the same yesterday, today and forever" (Heb. 13:8). He was in the beginning; i.e., was before the creation; before the foundation of the world; before the world was. No wonder he says, "Before Abraham was, I AM" (John 5:58). John uses the expression in John 1:1a to point to "a new beginning, a new creation" 96 as he recalls the first creation. The Word predates date and hence is before all things. Paul teaches this same truth in Colossians 1:16. Such an assertion prepares John's readers to acknowledge the fact that the Word is the Creator of all things (1:3) and again that he is life (1:4).

\section{Christ reveals God's Being}

Christ is the revealer of God to humankind (1:1a). Among the authors of the Bible, only John refers to Jesus as the Word of God. According to Hodge the term "the Word" expresses both the nature and the office of the Son. ${ }^{97}$ The "Word" is the one who expresses the nature of God, he is "the express image of [God's] person" (Heb. 1:3) such that whoever has seen him has seen the Father (John 14:9). In the current context, this expression is used to point out the Word's role as the expression of the divine intelligence and the disclosure of the divine essence. It expresses the office of the Son as the revealer of God. Similarly, Gordon J. Keddie is of the view that the reference to the Son as "the Word of God" signifies that he "eternally reflects the mind of God and, and in time and history, reveals that mind to humankind."98 W. E. Vine concurs saying, logos denotes "the expression of thought--not the mere name of an object...as embodying a conception or idea... a saying or a statement" ${ }^{\prime 99}$ by God or by Christ as opposed to

\footnotetext{
${ }_{96}$ Morris, The Gospel to John, 73.

${ }^{97}$ Hodge, Systematic Theology I, 489.

${ }_{98}$ Gordon J. Keddie, An EP Study Commentary on John vol. 1 chapters 1-12 (Auburn: Evangelical Press, 2001), 32.

99 W.E Vine, Expository Dictionary of New Testament Words vol. IV (New Jersey: Fleming H. Revell Company, 1966), 229.
} 
rhema which refers to that which is spoken or written.

Just as a person's word serves as how he or she reveals to others his/her thought, so the Word of God reveals God's thoughts to us. This means that the Son communicates to humanity something about God, his Father. Thus, Hodge rightly points out that, his office reveals God to his creatures. ${ }^{100}$ Jesus himself made this explicitly known when he said, "No one has seen God at any time; the only begotten Son who is in the bosom of the Father, he has made him known" (John 1:18). He communicates to people God's revealing and redeeming power. Craig L. Blomberg asserts that John might have exploited the diverse background of the term to drive home the point that "Jesus is the way in which the true, living God reveals himself and communicates with his people." as follows:

The Son, therefore, as the revealer of God, is the Word. The reason why John selected this designation of the divine nature of Christ, is not so easy to determine. It may indeed be said that there is ground for the use of the term in the usage of the Old Testament and of the Jews who were contemporaries with the Apostle. In the Hebrew Scriptures “God's revelatory act is often described by saying that the word of the Lord 'came' to the prophet." 102

\section{Christ and the Father have distinct Personalities}

John notes further that the Son has a distinct personality from the Father (1:1b). John's use of the preposition "with" implies that there were two persons: God and the Word, implying that the Word has a distinct personality from God. By this assertion, John was rejecting any idea that God has a uni-personality so that when he records in John 10:30 that Christ says, "I and my Father are one", his audience

\footnotetext{
${ }^{100}$ Hodge, Systematic Theology I, 505.

${ }^{101}$ Craig L. Blomberg, Jesus and the Gospels (Tennessee: Broadman and Holman Publishers, 1997), 162.

${ }^{102}$ Morris, The Gospel to John, 118.
} 
would not think that the Father and the Son are one person but rather that they are co-substantial, one substance, one essence, one nature (a concept he climaxes in the third part, 1c). This personal relationship between the Father and the Son also prepares readers minds for Christ's request "glorify me in your presence with the glory I had with you before the world began" (John 17:5). On this, Benjamin B. Warfield persuasively asserts that:

It is not merely coexistence with God that is asserted, as of two beings standing side by side, united in local relation, or even in a common conception. What is suggested is an active relation of intercourse. The distinct personality of the Word is therefore not obscurely intimated. From all eternity the Word has been with God as a fellow: He who in the very beginning already "was," "was" also in communion with God. ${ }^{103}$

The two distinct personalities are presented in this text, as having intimate relationship, before the creation of the earth (world).

\section{Christ is God}

Finally, John comes to the climax of his theological development when he writes "and the Word was God." John drives home the fact that even though the Word was in some sense second along with God, he has the same essence as God. The Word was distinct yet of the same substance as God. Whatever God was the Word was. In v. 2 he asserts that "The same was in the beginning with God" to point to the fact that it is the same pre-incarnate Word who came into the world. Akin quotes Tenney as saying, "The Word' was deity, one with God, rather than 'a god' or another being of the same class.... Unity of nature rather than similarity or likeness is implied. The external coexistence and unity of the Word with God is unmistakably asserted." 104 John would have us realize that there was never a time that the Son was not fully God. Between the Logos and the Father, there is not simply ${ }^{103}$ B. B. Warfield, The Person and Work of Christ (Philadelphia: The Presbyterian and Reformed Publishing Company, 1950), 53.

${ }^{104}$ As cited in Akin (ed.), A Theology for the Church, 495. 
a similarity of nature, but an identity of essence.

The NEB's paraphrase "what God was, the Word was", brings out the meaning of the clause as successfully as a paraphrase can... So, when heaven and earth were created, there was the Word of God, already existing in the closest association with God and partaking of the essence of God. No matter how far back we may try to push our imagination, we can never reach a point at which we could say of the Divine Word, as Arius did, "There was once when he was not."105 Luther's argument is that "John disposes of Arianism also because the Logos was eternally God, fellowship of the Father and Son, what Origen called the Eternal Generation of the Son (each necessary to the other). Thus, in the Trinity we see personal fellowship on an equality." Jo6 John's construction was carefully done to avoid the error of Sabellianism which teaches that there is but one God, who has manifested, first as Father, then as Son, and finally as the Holy Spirit. A statement like "In the beginning was the Word, and the Word was with God and the Word was the God", would have taught Sabellianism. The following quote from Tenney aptly summarizes the theological truth deducible from John 1:1:

The three statements in v.1 bring out... different aspects of the nature of the Word. The first speaks of His pre-existence. The second statement, "The Word was with God," is an assertion of the Word's distinctiveness. The preposition pros [rendered "with"] indicates both equality and identity. [A.T.] Robertson says, "The literal idea comes out well, "face to face with God" ... This implies personality and coexistence with God. The third statement, "The Word was God is especially significant. This is a clear statement of deity."107

\footnotetext{
${ }^{105}$ Bruce, The Gospel of John, 31.

${ }^{106}$ A. T. Robertson, Word Pictures in the New Testament vol. 5 (Grand Rapids: Baker Book House, 1932), 4-5.

${ }^{107}$ As cited in Akin (ed.), A Theology for the Church, 494.
} 


\section{Conclusion}

The study has established that Christ is coequal, coeternal, coexistent, and consubstantial with the Father. The deity of Christ is very crucial in Christological reflections. If Christ is not God then we have no purpose for continuing this study, no reason for continuing with church attendance, no purpose for reading the Bible, and no purpose for following any of the Lord's teachings. Indeed, we may as well call home the missionaries. There would have been no purpose to Christianity.

The significance of this study is seen in the fact that its outcome affects the deity of Christ and hence the doctrine of the Trinity. For, if the Word was "a god," then by implication there are other gods of which Christ is one. On the other hand, if theos is just as definite as the articular construction following the verb because, "the dropping of the article... is simply a matter of word-order," 108 then the doctrine of the Trinity is denied and we would be left with pure Sabellianism. Once we understand that at least two personalities existed before the beginning of time, we are being prepared to understand the concept of the Trinity which asserts that "God eternally exists as three persons, Father, Son and Holy Spirit, and each person is fully God, and there is one God." 109

\footnotetext{
${ }^{108}$ Nigel Turner, Grammatical Insights into The New Testament (Edinburg: T\&T Clark, 1965), 17.

${ }^{109}$ Grudem, Systematic Theology, 226.
} 


\section{Review Exercise}

1. What biblical evidence are there in John to prove the preexistence of Christ?

2. In what sense can we say that John was influenced by Greek philosophy in his application of the term Logos to Christ?

3. What is the Jewish understanding of the term Logos? How does it contribute to Christology?

4. To what extent is Jesus Christ the revealer of God's being?

5. Is Christ God or a god according to John 1:1c? Explain your answer.

6. "Christ is equal but subordinate to the Father." Discuss. 


\section{CHAPTER 4 \\ INCARNATION CHRISTOLOGY \\ (JOHN1:14a)}

We have stated earlier that the Christian faith centers on the person of Jesus Christ. Prominent questions people ask about the person of Christ include: Is Jesus a human being, God or both human and God? This chapter conducts a critical exegetical and theological reading of the expression "Kai ho Logos sarx egeneto" (John 1:14a) in an attempt to answer this question. At the end of the study, the authors found that the incarnation of the divine Logos is the foundational truth upon which true Christology rests and that the doctrine of the true humanity of Christ is as indispensable to the Christian faith as is the doctrine of his deity. Therefore, any Christology that does not balance the humanity and divinity of Christ is theologically unacceptable.

\section{Contextual Issues}

The exegesis in this chapter is based on the contextual analysis conducted in the previous chapter. The passages in the previous and the current chapters fall under one unit and so they have similar contexts, both historically and literally. Carson gives a summary of contextual analysis, "The Prologue summarizes how the 'Word' which was with God in the very beginning came into the sphere of time, history, tangibility." ${ }_{110}$ In verses 1-3, John spoke of the relationship of the Logos to God, but in verse 14, he examines the Logos' relationship to the world. The statement "Kai ho Logos sarx egeneto", ("And the Word become flesh", v. 14a) is pivotal in the

\footnotetext{
${ }^{110}$ Carson, The Gospel According to John, 111.
} 
Christology of the fourth gospel because it answers what we consider the most important question in John's gospel: "Who is Jesus?" The text looks short if measured by its words, but very long if measured by its contents. In what follows we attempt an exegesis of John 1:14a.

\section{Close Reading of John 1:14a}

The Greek text reads: Kaì ò $\lambda$ ó

Our transliteration gives: Kai ho logos sarx egeneto

Our translation yields: And the Word became flesh

\section{Kai ho Logos}

Kai is a conjunction meaning "and", "also", "even", "so then", "too" etc. It resumes v. 11, and opens a statement of the incarnation in more theological terms. The Greek word ho is an article (nominative masculine singular), meaning "the." The use of the definite article signifies that he (the Word) is not merely a concept of God.

The previous chapter investigated the background of the term Logos. We present a summary as follows. The term Logos, a nominative masculine singular noun, plays a very key role in our study. Logos is used in a Christological sense only in the prologue of John's gospel. Logos derives from legoo, meaning "to lay", "pick out", "gather", "pick up"; that is, "to gather" or "put words together", and so, to speak. ${ }^{111}$ Logos could mean "word," "speech," "matter," "thing," "command," "message," "account," "reckoning," "settlement," "respect," "reason," and so on. ${ }^{12}$ The Logos appears four times in v. 1, 14: the Logos was in the beginning; the Logos was with God; the Logos was God; the Logos became flesh (human).

Greek philosopher, Heraclitus used Logos to signify "didactic discourse," "word," and even "reputation" as well as

\footnotetext{
111 Vincent, Word Studies vol. 2, 25.

${ }^{112}$ William F. Arndt and F. Wilbur Gingrich, A Greek-English Lexicon of the New Testament and other Early Christian Literature (Chicago: The University of Chicago Press, 1957), 478-80.
} 
"proportion,"“"meaning," "universal law," and "truth." ${ }^{113}$ It also meant the principle which gives shape, form, or life to the material universe. In Stoicism, it was used to designate "the animating life force or "world soul" that permeated all the universe." 114 The Greek concept of Logos may summarize as, "inward thought, and the outward expression of thought in speech." 115 The Logos was considered as a productive power in Greek philosophy. According to Ladd, "the divine Logos was called the spermatikos logos, the Seminal Logos or generative principle of the world. This vital energy both pervades the universe and unfolds itself into innumerable logoi spermatikoi or formative forces that energize the manifold phenomena of nature and life." $" 116$

The Hebrew equivalence for logos is dāa $\bar{a} r$ which is used to signify communication from God to humanity (God's people), prophetic revelation (Ezek. 1:3; Amos 3:1). The OT also has instances where the manifested Yahweh is the Word of God (see Ps. 33: 6; 119:89; Is. 40: 8; Ps. 107:20; 147:18). The Word of God is creative (cf. Gen. 1.3,6,9, etc.). In the OT, Logos is not abstract but spoken and active.

After his silence about the Logos between verse 2 and 13, John needed to restate it as the subject in order to avoid ambiguity. In both verses, John uses the term without explanation, an indication that his readers were familiar with it. The meaning of Logos in v. 14 is not different from its meaning in v. 1. The expression "ho Logos" as a proper name is never used in the gospel after v. 14. This, according to John F. Mchugh, "must mean that it was there intended as a technical term for the pre-existent Word up to the moment of [the] Incarnation

\footnotetext{
${ }^{113}$ Verlyn D. Verbrugge, The NTV Theological Dictionary of New Testament Words: An Abridgment of New International Dictionary of New Testament Theology (Grand Rapids, MI: Zondervan Publishing House, 2000), 759.

${ }^{114}$ Craig L. Blomberg, Jesus and the Gospels (Tennessee: Broadman and Holman Publishers, 1997), 162.

${ }^{115}$ C. K. Barret, The Gospel According to St. John: An Introduction with Commentary and Notes on The Greek Text Second Edition (Philadelphia: Westminster Press, 1978),

${ }^{116}$ Ladd, A Theology of the New Testament, 275.
} 
(1.14)." 117 As applied to Christ in John's gospel, the term Logos is personal rather than a principle. John's perspective agrees with the OT understanding of the Word of God but clearly differs from the Greek understanding. Like the Greek conception of human's inability to reach logos, John's logos came down and dwelt among us because we could not reach him ourselves. In Johannine Prologue, the Logos is both creative and revelatory. That John was familiar with the OT and with Judaism seems evident. The following quote from Vincent summarizes our discussion so far, "The Logos of John is the real, personal God (1:1), the Word, who was originally before the creation with God, and was God, one in essence and nature, yet personally distinct $(1: 1,18)$; the revealer and interpreter of the hidden being of God; the reflection and visible image of God, and the organ of all His manifestations to the world." 118

\section{Sarx}

The noun sarx is nominative feminine singular. It has three forms: sarx, usually rendered flesh; sarkikos, usually carnal, sometimes fleshly, and sarkinos, fleshy. The most basic meaning of sarx is "the material that covers the bones of an animal or human body." John uses sarx to refer to flesh, human nature, which describes the new mode of being of the divine Logos. There is a juxtaposition of 1:1c and 1:14a of the Logos in the two different settings to form a paradox, the Word was fully God and is now completely "flesh." Aside its use in John 1:14, sarx is used in other texts: six times in $1.13,14 ; 3: 6 ; 6: 63$; $8: 15 ; 17: 2$; plus one occurrence in each verse of the six verses from 6:61 to 6:56. In 1:14, sarx is used as synecdoche for anthropos. It does not therefore signify just flesh but the whole human being, bones and blood, spirit and soul. Vincent observes rightly that sarx "signifies human nature in and according to its corporeal manifestation. Here,

\footnotetext{
117 John F. Mchugh, "A Critical and Exegetical Commentary on John 1-4" in The International Critical Commentary on The Holy Scriptures of The Old and New Testaments edited by G. I. Davies and G.N. Stanton (eds.) (London: T\&T Clark, 2009), 51.

${ }^{118}$ Vincent, Word Studies vol. 2,
} 
as opposed to the purely divine, and to the purely immaterial nature of the Word." 119

John could have used the word anthropos but instead, he used sarx. Mchugh gives some possible reasons for which John preferred sarx to anthropos. ${ }^{120}$ First, the text could have been misread as the Logos was changed into a human view, an idea which was common in Greek mythology. Second, the Jews could have taken it to mean a heavenly human being who was thought to have existed before creation. We do not find this argument convincing since "John does not say this of the Logos, and if vv. 14-18 reflect Son of man ideas they do so very faintly." 121 Mchugh gives a third and most important reason as follows: John used sarx because "sarx, more than anything else in the material creation, is diametrically opposed to the Logos. Flesh is the most vulnerable, the most corruptible, the most easily destructible, part of the human being - in a word the most impermanent." 122

Sarx does not signify a personality but human nature. From the very beginning of his prologue, John teaches that the Logos has a divine personality. Now, in verse 14, he is teaching that the Logos assumed human nature entirely, identifying himself with humanity. By becoming sarx, the Logos now possesses a human soul, body and spirit. "He became flesh, and did not clothe [h]imself in flesh."123 It is important to state that in John, sarx does not refer to "fflesh' as corrupted by sin (frequent in Paul) but for flesh as mortal and physically weak." 124 For C. K. Barrett, "sarx, as in v. 13, represents human nature as distinct from God, but expresses this in the harshest available form, harsher than those of v. 6, where John the Baptist is described as anthropos." 125

\footnotetext{
${ }^{119}$ Vincent, Word Studies vol. 2, 51.

${ }^{120}$ Mchugh, "A Critical and Exegetical Commentary on John 1-4", 52.

${ }^{121}$ Barret, The Gospel According to St. John, 165.

${ }^{122}$ Mchugh, "A Critical and Exegetical Commentary on John 1-4", 53.

${ }^{123}$ Vincent, Word Studies vol. 2, 51. Emphasis original.

${ }^{124}$ Ibid.

${ }^{125}$ Barret, The Gospel According to St. John, 164-165.
} 


\section{Egeneto}

The verb egeneto, rendered "to become", is the aorist form of ginomai and indicates action at a point of time. In the present context, it refers to a specific point in time, the incarnation. It is used of the things that were created in verse 3 (came into being), of John the Baptist in v. 6 (There was), and of the world in v. 10 (came into being).

The exact meaning of egeneto is difficult to determine. The English verb "became" does not give the best meaning of the Greek word. "Became" should not be understood as ceasing to be what it used to be and changing into another form. In becoming he did not cease to be what he was in the beginning. ${ }^{126}$ That is, the positive acquisition of something (human nature), not the loss of anything (divine nature). He assumed what he was not (human) while remaining what he was (divine). The Word continues to be the subject of further statements, for instance, the Word "dwelt among us", and "we beheld" the Word's glory; the Word continued to be the Word. Barrett is right in pointing out that the egeneto "is used in the same sense as in v. 6: the Word came on the (human) scene-as flesh, [hu]man."127

Yet, the use of egeneto offers the evangelist the opportunity to avoid creating the impression that the human flesh of Jesus was something quite external to Jesus, something that he clothed himself with and could discard at will at any time. Since the Word was described in v. 1 as God, John's statement in v. 14 is a full expression of the paradox of Christ's personality. John combines 1:1 with 1:14 to contend that there was a time when Jesus of Nazareth did not exist; there was also a time when the theanthropic person, Jesus Christ, did not exist but there has never been a time when the Logos (the Son of God) did not exist. Mullins' point is apt, 'He [the man Jesus] is not from eternity past, as it is true of his Godhead. He became [hu]man at a particular point in time through incarnation." 128

\footnotetext{
${ }^{126}$ Vincent, Word Studies vol. 2, 50.

${ }^{127}$ Barret, The Gospel According to St. John, 165.

${ }^{128}$ Mullins as quoted by Akin (ed.), A Theology of the Church, 540.
} 


\section{Christology of John 1:14a}

The Christology deducible from the exegesis sums up as follows: There are two natures of Christ inseparably united without mixture or loss of separated identity. Said differently, in Christ is the union of the unapproachable divine nature with the limited human nature. This union of the human and divine natures of Christ is theologically referred to as Hypostatic Union. Three important facts come out of the above definitions: (1) Christ possesses two distinct natures, namely, humanity and deity; (2) The two natures possessed by Christ are not intermingled and (3) Christ is one person. We shall proceed to explain each aspect of the Hypostatic Union.

\section{Christ possesses two distinct Natures: Humanity and Divinity}

The first theological deduction from the exegetical reading of the text is that Christ is both human and God. The dual nature of Christ was effected by the Incarnation of the eternal Logos. By incarnation is meant the "enfleshment" of the Second Person of the Trinity. It is the act through which the Second Person of the Trinity, without ceasing to be what he is, took into union with himself what he, before that act, did not possess, that is human nature. In the event of his incarnation, Christ "truly and genuinely invaded time and space, taking to himself real humanity." 129

There is biblical evidence to show that Jesus had body just like our human bodies. Even though he was not conceived through natural means, his birth was normal and not extraordinary (see Isa. 7:14, Matt. 1:23 cf. Luke 2:7), and he had many human experiences. He advanced in wisdom and stature (Luke 2:52 cf. Luke 2:40). Like any human being, Christ became tired (John 4:6); thirsty (John 2:8) and hungry (Matt. 4:2); physically weak at some point, and could not carry his cross (Luke 23:46). More so, he had a human soul (or spirit) which, at some point, was troubled (John 12:27; cf. 13:21). Like any other human, Christ's soul became sorrowful (John 11:35;

\footnotetext{
${ }^{129}$ Akin (ed.), A Theology of the Church, 535.
} 
Matt. 26:38).

Christ's humanity is as real as that of Adam. In this light, Adam is referred to as the first man, and Christ as the last Adam. Adam's humanity before the fall, when he was sinless, typifies Jesus' humanity. The nature of his conception made him have no share in Adam's sin. As a sinless human, Christ is the truest and most genuine expression of human nature.

The incarnation was a permanent act; Christ will possess human nature forever. The NT testifies that Christ did not give up his human nature after his death and resurrection. He appeared to his disciples and showed them the scars on his glorious body (John 20:25-27), he had "flesh and bones" (Luke 24:39) and ate food (Luke 24:41-42). The two angels who appeared at his ascension prophesied that he would come the same way he was taken (Acts 1:11). Stephen (Acts 7:56) and Paul (Acts 9:5) both had a vision of Jesus in human form. In the Parousia Christ will appear in bodily form.

The incarnation of the Son did not in any way deprive him of his divine nature. The expression "the word became flesh" does not mean that the Word ceased to be the Word and became flesh; that would be metamorphosis, not incarnation. Neither did the human Jesus at some point become more than human; that would be divinization, not incarnation. Rather, he retained "all the essential properties of the Word, [but] entered into a new mode of being, not a new being." "Without ceasing to be God through whom all things were made, he concurrently became [hu]man by assuming our flesh." 131 That Jesus Christ was God is attested in the passage. At the beginning of the prologue John taught that the Logos pre-existed with God, and was God himself. Throughout his gospel account, John presents Jesus as God.

Christ is the Creator (1:3, Col. 1:16); eternal, omnipresent, omnipotent, omniscient etc. Therefore, the incarnation in no way

\footnotetext{
${ }^{130}$ Vincent, Word Studies vol. 2, 51

${ }^{131}$ J. Rodman Williams, Renewal Theology: Systematic Theology from a Charismatic Perspective three volumes in one (Grand Rapids, MI: Zondervan, 1996), 305.
} 
makes the Son inferior to the other members of the Trinity. The Father sent the Son. There is a functional, not essential, subordination of the Son to the Father, an "innerrelationship that exists within the Godhead."132 The fact that the Son is in no way inherently inferior to the Father is taught in 1:1, where the Son is said to be "coequal, coeternal, coexistent, and consubstantial with the Father." 133 It will be contradictory for the same author to say, fourteen verses later, that the Son is inferior to the Father. Theologically, John (1:1) affirms subornation of order or function but not of essence. It is in the economic Trinity that the Son occupies a secondary position only voluntarily, not metaphysically.

\section{Christ's Human and Divine Natures are not intermingled}

The enfleshment of the Logos makes the Logos possess dual nature, divine nature and human nature. Through the birth of Jesus his human nature was forever added to his divine nature. The human nature added did not mix with the divine nature, but instead, remained distinct, whole, and unchanged. Christ was a theanthropic Person but did not have a confused or intermingled theanthropic nature. The divine and human attributes were distinct and not mixed. ${ }^{134}$

Christ possesses not two self-consciousnesses but one Ego or self-consciousness manifested in two forms or levels. As Macleod puts it, "There are two levels of consciousness of the one self. There is a divine consciousness that he is the eternal Son of God, and there is a human consciousness of the same fact. The two forms of consciousness remain distinct, [not intermingled] united in one person, communicating through the Holy Spirit."135

\footnotetext{
${ }^{132}$ Akin (ed.), A Theology of the Church, 535

133 Ibid., 494.

${ }^{134}$ J. C. Ryle, Expository Thoughts on John vol. 1 (Edinburg: The Banner of Truth Trust, 2009), 26.

${ }^{135}$ Macleod as cited by Akin (ed.), A Theology of the Church, 536.
} 


\section{Christ is one Person}

The possession of two distinct natures (human and divine) does not make Jesus Christ a double or compound being or some kind of hybrid being. The term "person" refers to "the self-conscious, self-asserting, and acting subject" while " nature' constitutes the totality of powers and qualities which constitutes a being." 136 The human nature, by virtue of the union with the divine Person, acquired personality. Christ's human nature was therefore not personalized out of the race by natural birth, but by becoming a component of the theanthropic person. Expressions such as "the seed of the woman" (Gen. 3:15) and the seed of Abraham (Gen. 12:3) should be understood that the human nature assumed by Christ was not as yet individualized. ${ }^{137}$ John's use of the expression "flesh" rather than "human" is significant to point out the fact that Christ "had no other personality than that which subsisted in the divine nature." ${ }^{138}$ Christ was a full and complete human whose consciousness and will developed only in union with the personality of the divine Logos. In other words, Christ's human nature did not have its own personality. It derived personality from the divine Logos.

That the human nature of Christ had no personality on its own but derived one from the divine nature falls in line with the Akan understanding of the concept of personhood. The Akan word for person or human being is onipa (or nipa), commonly described as a tripartite entity. ${ }^{139}$ The first component is the honam/nipadua, the tangible part of a person, which is made from the mogya, blood, of the mother. It is believed that it is the mogya that binds children physiologically closer to the mother than the father. ${ }^{140}$ The second part is the sunsum, an individual spirit, which bears one's personality.

\footnotetext{
${ }^{136}$ Akin (ed.), A Theology of the Church, 536.

${ }^{137}$ H. Orton Wiley and Paul T. Culberson, Introduction to Christian Theology (Kansas City: Beacon Hill Press of Kansas City, 1946), 199.

${ }^{138}$ Wiley and Culberson, Introduction to Christian Theology, 199.

${ }^{139}$ See K. A. Appiah, "Akan and Euro-American Concepts of the Person” in Lee M. Brown (ed), African Philosophy: New and Traditional Perspectives, Oxford: Oxford University Press, 2004), 28.

${ }^{140}$ A. R. Radcliffe-Brown et. al (eds), African Systems of Kinship and Marriage (London/New York/ Toronto: Oxford University Press, 1975), 264.
} 
The sunsum derives from the father at conception. ${ }^{141}$ The last entity is the okra, (the soul) the bearer of ones nkrabea, or destiny and it comes from God. Some scholars hold a pentachotomistic view which adds a fourth element, ntors to the three elements outlined above. According to this view the ntors which is responsible for the cast of one's personality (the semen) comes from the father.

Therefore, whether one holds a tripartite or pentachotomistic view of the person, the element responsible for a child's personality comes from the father. This means that one can have human personality only if he/she is conceived through the sexual union of a man and a woman, so that the personality will be derived from the father. In the case of Jesus Christ, who had no biological father, there is neither sunsum nor ntors from any man to give him human personality. The Akan worldview of human person, indicates that the nnipadua, the tangible part, comes from the mother. Therefore, in the case of Jesus, his flesh came from Mary but it was without human personality because no sexual intercourse took place to bring about his conception. This is exactly what the doctrine of Incarnation teaches. Therefore, the incarnation must be understood as "the union of the divine Person with human nature, and not with a human person."

The fact that the theanthropic personality depended on the divine personality can be seen in the fact that it was not destroyed by death. While there was a temporal separation between Christ's body and his soul when he died, there was never a time that the divine Logos separated from either the human soul or body. Christ's body could not see corruption because his human soul and body were united with the divine Logos even at his death. ${ }^{143}$

A person may have more than one nature within him/herself. The human person has two natures, namely, material and immaterial nature, existing in the same person. Christ as a theanthropic person may be said to possess three natures, namely the divine nature,

\footnotetext{
${ }^{141}$ Radcliffe-Brown et. al (eds), African Systems of Kinship and Marriage, 266.

${ }^{142}$ Wiley and Culberson, Introduction to Christian Theology, 199.

${ }^{143}$ Ibid., 201.
} 
human soul and a human body. The latter two are combined when we speak of two natures of Christ. That is in order because these two natures combine to give the human nature. The union of these natures is made possible by the single personality he possesses. The union between the two natures of Christ is likely to be stronger than that which exists between the human body and soul because the latter union is separated by death while the former (that is union between human and divine natures of Christ) is inseparable. In conclusion, Jesus Christ was not God and a human - two persons, but the Godhuman-one person.

\section{Implications of the Incarnation}

The message of John 1:14 is very significant for Christians. The incarnation made representative obedience possible. Adam represented humanity who disobeyed God in the Garden of Eden; Christ represented humanity that obeyed God's Law for us. ${ }^{144}$ Paul draws attention to this fact, when he says that all became sinners due to one person's disobedience but all have been made righteous through one person's obedience (Rom. 5:18-19). The Logos had to be made flesh in order to obey God fully in our stead.

The incarnation also made it possible for Christ to die in our stead and pay an acceptable price for our redemption. His theanthropic nature makes him the one and only human being to live a blameless life before God (Heb. 7:26) and offer his life as a sacrifice for the entire world (v. 27), a sacrifice that could not have been accomplished in any other way. Through the incarnation, he identified with humanity (Heb. 2:9), remained sinless (4:15), and gave his life as a ransom for all $(9: 12)$, so that all those who would believe in him can enter a new relationship with God that is eternal in nature (Rom. 5:2). The redemptive nature of Christ will only be adequate if both natures are fully represented in one person. Our salvation therefore depends on the two natures of Christ; one nature

${ }^{144}$ Grudem, Systematic Theology, 540. 
gives no hope of salvation without the other. A more human than divine person cannot be blameless, and a more divine that human person can neither completely self-identify with those he came to save nor offer a sacrifice with an infinite value sufficient enough to pay for the sin of the world. ${ }^{145}$

The incarnation raises the dignity of humanity. Psalm 8 talks about how humankind is dignified in creation. This dignity is raised to the highest possible level as God assumes human nature. By assuming human nature, Christ raises humanity to a dignity beyond compare.

"For by his incarnation, the Son of God has united himself in some fashion with every [hu]man." 146 The Incarnation put God's seal upon human dignity. In Greek Philosophy, the body is like an evil cage that has trapped the soul. The body was what the Greek sought to escape, not become. John's words, "And the Word became flesh was therefore very unacceptable." Yet, it points to the fact that God actually dignifies the human body. God becoming human forever points to the fact that he really loves people and has made them differently from other creatures. His incarnation restores our nature as well.

\section{Conclusion}

To sum up, for Christology to be biblically and theological acceptable, there should be a balance between the humanity and divinity of Christ. Christ is fully God, fully human, and yet one person. In conclusion, the study draws some implication for its findings for certain Christological heresies that bother on the personality of Christ. Firstly, any Christology that diminishes either the humanity or divinity of Christ (including Docetism, Arianism, and Apollinarianism) must be

\footnotetext{
${ }^{145}$ Paul Enns, The Moody Handbook of Theology, revised and expanded (Chicago: Moody Publishers, 2008), 239.

${ }^{146}$ Walter Msgr. Niebrzydowski, The Cosmic Countdown: God, Humanity, and the Evolving Universe (np:np, 2012), n.p. see chapter 18. https://books.google.com.gh/books?id=y0VdDQAAQBAJ\&p $\mathrm{g}=$ PT56\&lpg
} 
rejected. ${ }^{147}$ Secondly, the above doctrine rules out Nestorianism, ${ }^{148}$ which divided the natures as persons, thus destroying the unity and uniqueness of Christ's body. Obviously, the doctrine rules out any separation between Christ of faith and Jesus of history. Thirdly, the continuity of the Son's personality rules out adoptionism because in the Hypostatic Union the Christ's human nature does not have an independent personal subsistence. Adoptionism is the belief that Christ was an ordinary human being whose humanity was adopted into divinity through a gradual process. ${ }^{149}$ Finally, our study rules out Euthychianism. The incarnation of the Logos led to theanthropic person who retained the two natures, human and divine. In conclusion, to deny either the undiminished deity or the perfect humanity of Christ is to put oneself outside the pale of theological orthodoxy.

\section{Review Exercise}

1. Explain the term incarnation.

2. How does the incarnation of Christ add to human dignity?

3. Clearly explain the term hypostatic union.

4. Is Christ one person or two persons? Explain your answer.

5. How does Akan anthropology relate to the dual nature of Christ?

6. What role does the incarnation of the Logos play in God's salvific agenda?

\footnotetext{
${ }^{147}$ See chapter one for discussions on these heresies.

${ }^{148}$ Nestorius was the bishop of Constantine in the fourth century.

${ }^{149}$ Walter A. Elwell (ed.) Evangelical Dictionary of Theology 2nd edition (Grand Rapid, MI: Baker Publishing Group, 2001), 26.
} 


\section{CHAPTER 5 \\ HUMILIATION-EXALTATION CHRISTOLOGY (PHILIPPIANS 2:5-11)}

This chapter examines one of the Christ-hymns in the NT (Phil. 2:611). ${ }^{150}$ It aims at discussing the humiliation and exaltation of Christ through exegetical analysis of the text. Key words in the text are critically examined to determine the meaning of the passage. The study found that the incarnation, climaxed at the crucifixion, brings out God's character to human understanding. The concept of selfemptying, how it has been misrepresented and how it should be interpreted, is also very crucial in the study. At the end, the study gives the reader a broader perspective of humiliation and exaltation of Christ.

\section{Background to the Epistle to the Philippians}

The epistle to the Philippians derives its name from the Greek city where the church it was addressed to was located. Philippi was the first town in Europe where Paul established a church. ${ }^{151}$ Its establishment is recorded in Acts 16. That Paul wrote the epistle to the Philippians is not in any serious contention. Paul wrote the book of Philippians

\footnotetext{
${ }^{150}$ By way of definition, Christ hymns are early Christian hymns that were sung in worship and praise to Jesus Christ. They give insight into the two estates of Christ, namely, humiliation and exaltation.

They are confessional and liturgical and tell us the Christology of the early church. They also teach us about worship and hymnody in the early church. The content of these hymns, as we shall discover from our studies, show that the early church had an explicitly high Christology. The early church, as revealed by the hymns, believed in both the divinity and humanity of Christ. Most of the hymns existed before their citation in the NT and for that matter they are more primitive than the NT as to their origin. They have exalted language and rhythmic quality. Other Christ hymns include Col. 1:1520, Heb. 1:1-4 etc.

${ }^{151}$ Guthrie, New Testament Introduction, 522
} 
around 60 AD. while in prison. Before this letter, the Philippian church had sent Paul some gifts through Epaphroditus (4:18). Paul sent this letter through Epaphroditus on his return journey. The letter was multi-purposed. Paul wrote to show appreciation for the financial assistance given him, to counteract any tendency toward divisiveness in their heart $(2: 4 ; 4: 2)$, to caution the Philippians against Judaizers (chapter 3), and to prepare them for the impending visit of Timothy and his own visit as well (2:19-24). Third, he wanted to inform them about his circumstances in Rome (1:12-26). Finally, he wrote to warn them against false teachers $(3: 1-4: 1)$. Concerning the place where the letter was dispatched, scholars have suggested Caesarea, Rome or Ephesus.

\section{The Christ hymn of Philippians 2:6-11}

There is much debate as to whether or not Paul is the original author of Phil. 2:6-11. While it is believed that Paul authored the hymn, there are also two other traditions that reject Pauline authorship on the basis that the hymn exhibits a non-Pauline style and theology. ${ }^{152}$ The first of those traditions argue that the hymn was a later interpolation. The second says Paul, while composing his letter, cited this hymn to make his point. These two traditions are divided as to whether the hymn is pre-Pauline or contemporaneous with Paul. Manuscript evident for the interpolation theory is lacking. ${ }^{153}$ The issues in the debate lead to uncertainty about the authorship of this hymn. Yet, it is clear that the hymn forms a significant part of Paul's plea to the Philippians to pursue unity. ${ }^{154}$

Philippians 2:6-11 is loaded with rich Christology. Gerald Hawthorne describes it as "a Christological gem unparalleled in the New Testament." 155 For Gordon R. Demarest and Bruce A. Lewis it is

\footnotetext{
${ }^{152}$ See for example, David Alan Black, "The Authorship of Philippians 2:6-11: Some Literary-Critical Observations" in Criswell Theological Review 2.2 (1988) 269-289.

${ }^{153}$ Guthrie, New Testament Introduction, 540.

${ }^{154}$ Moises Silva, Philippians in Baker Exegetical Commentary on the New Testament (Chicago, IL: Moody Press, 1998), 105.

${ }^{155}$ Gerald Hawthorne, "Philippians" in WBC (Waco: Word, 1993), 79.
} 
"the crowning jewel of Christological texts."156 Paul's Christology in this hymn, like John's in his prologue to his gospel, is a Christology from above in which he begins with the pre-existent state of Christ and then descends to his earthly life and ministry and finally talks about his incarnation. The text asks whether "the cross of Jesus Christ actually can be included in the identity" of Israel's exalted God, and answers that Christ's "humiliation belongs to the identity of God as truly as his exaltation does." "157 The "real theological emphasis of the hymn", according to N. T. Wright, "is not simply a new view of Jesus" but "a new understanding of God." 158 This new understanding of God is depicted by C. S. Lewis in the following words:

In the Christian story God descends to re-ascend. He comes down; down from the heights of absolute being into time and space, down into humanity.... But he goes down to come up again and bring the whole ruined world up with Him. One has the picture of a strong man stooping lower and lower to get himself underneath some great complicated burden. He must stop in order to lift, he must almost disappear under the load before he incredibly straightens his back and marches off with the whole mass swaying on his shoulders. Or one may think of a diver, first reducing himself to nakedness, then glancing in midair, then gone with a splash, vanished, rushing down through green and warm water into black and cold water, down through increasing pressure into the deathlike region of ooze and slime and old decay; then up again, back to color and light, his lungs almost bursting, till suddenly he breaks surface again, holding in his hand the dripping, precious thing that he went down to recover. ${ }^{159}$

\footnotetext{
${ }^{156}$ Gordon R. Demarest and Bruce A. Lewis, Integrative Theology vol. 2

(Grand Rapids, MI: Zondervan, 1996), 267.

${ }^{157}$ Richard Bauckham, Jesus and the God of Israel: God Crucified and Other Studies on the New Testament's Christology of Divine Identity (Grand Rapids: Wm. B. Eerdmans, 2008), 45.

${ }^{158}$ N. T. Wright, The Climax of the Covenant: Christ and the Law in Pauline Theology (London: T\&T Clark Ltd., 1991), 84.

${ }^{159}$ C.S. Lewis as cited in Will Vaus, Mere Theology: A Guide to the Thought of C. S. Lewis (Downers Grove: InterVarsity Press, 2004), 48.
} 


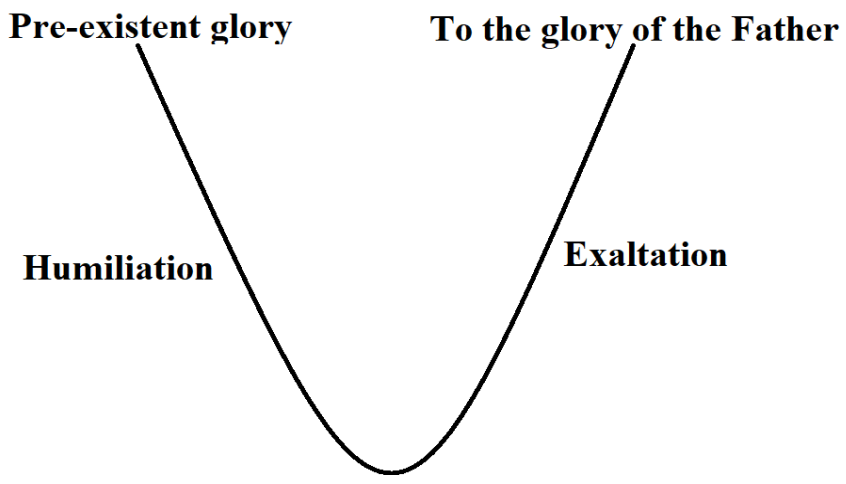

\section{Literary Structure of Philippians 2:6-11}

In its simplest form the hymn is arranged into two stanzas: stanza 1 comprises vv. 6-8, Christ's humiliation and stanza 2, comprising vv. 9-11, Christ's exaltation. The hymn may be structured in the form of chiasm as follows:

A who, though he was in the form of God, did not regard equality with God as something to be exploited,

B but emptied himself, taking the form of a slave,

C being born in human likeness.

$\mathrm{C}^{1} \quad$ And being found in human form,

$\mathrm{B}^{1}$ he humbled himself and became obedient to the point of death- even death on a cross.

$\mathrm{A}^{1} \quad$ Therefore God also highly exalted him and gave him the name that is above every name, so that at the name of Jesus every knee should bend, in heaven and on earth and under the earth, and every tongue should confess that Jesus Christ is Lord, to the glory of God the Father.

A and $\mathrm{A}^{1}$ represent respectively Christ's pre-earthly existence and 
glorious post-earthly existence

$\mathrm{B}$ and $\mathrm{B}^{1}$ represent Christ's vicarious death on the cross, a slave-like death.

$\mathrm{C}$ and $\mathrm{C}^{1}$ represent Christ's incarnation.

\section{The State of Humiliation (vv. 6-8)}

In this hymn Paul presents Christ in strikingly contrasted conditions of humiliation and exaltation. Phil 2:6-8 teaches Christ's voluntary self-humiliation. It comprises the incarnation, earthly life, suffering and death. The incarnation is preceded by the pre-existent state. Michael J. Gorman deduces the following narrative, semantic, and syntactic patterns in Phil 2:6-8. ${ }^{160}$

\begin{tabular}{|l|l|l|l|}
\hline & 26a & $\mathbf{2 : 6 b}$ & \multicolumn{1}{|c|}{$\mathbf{2 : 7 - 8}$} \\
\hline Text & $\begin{array}{l}\text { although [in } \\
\text { the form of } \\
\text { God] }\end{array}$ & $\begin{array}{l}\text { did not } \\
\text { [exploit } \\
\text { equality } \\
\text { with God] }\end{array}$ & $\begin{array}{l}\text { but [emptied himself } \\
\text {... humbled himself] }\end{array}$ \\
\hline $\begin{array}{l}\text { Narrative } \\
\text { Pattern }\end{array}$ & although [x] & not [y] & but [z] \\
\hline $\begin{array}{l}\text { Semantic } \\
\text { Pattern }\end{array}$ & $\begin{array}{l}\text { Although } \\
\text { [status] }\end{array}$ & $\begin{array}{l}\text { Not } \\
\text { [selfish act/ } \\
\text { selfishness] }\end{array}$ & $\begin{array}{l}\text { but [selfless acts/ } \\
\text { selflessness] }\end{array}$ \\
\hline $\begin{array}{l}\text { Syntactic } \\
\text { Pattern }\end{array}$ & $\begin{array}{l}\text { Concessive } \\
\text { participle }\end{array}$ & $\begin{array}{l}\text { negated } \\
\text { [verb] }\end{array}$ & alla + [affirmed verbs] \\
\hline
\end{tabular}

The narrative shows a "downward mobility", 161 that is, a progressively downward movement of status. In this text, Paul represents Jesus'

\footnotetext{
${ }^{160}$ Micheal J. Gorman, Inhabiting the Cruciform God: Kenosis, Justification, and Theosis in Paul's Narrative Soteriology (Grand Rapids, MI: Wm. B. Eerdmans Publishing Co., 2009), 17.

${ }^{161}$ A. Katherine Grieb, "The One Who Called You: Vocation and Leadership in the Pauline Literature," Int 59 (2005): 154-65, 158.
} 
humiliation in three main verbs modified by participles that signify "three progressively degrading positions of social status in the Roman world ... equality with God; ... taking on of humanity and status of slave; ... [and] public humiliation of death on a cross," the "utter degradation."162 Christ's self-emptying and self-humbling represent the succession of downward movement in rank and stresses the reality of the downward movement. The correspondence between the self-emptying of the pre-existent Christ and the self-humbling of the human Jesus is captured well in the following words: "The preexistent Christ's self-emptying, self-lowering incarnation/enslavement finds a parallel action in the human Jesus' self-humbling, self-lowering obedience to the point of death by crucifixion. The fundamental character of the actions taken by the 'form of God' and the 'form of a slave,' by the preexistent one and the incarnate one, is the same: downward movement." 163 We now look at the details of what the humiliation entails.

\section{The Pre-existent Being (v. 6a)}

The opening verse talks about the pre-existent Christ who became the historical Jesus. Paul expresses the idea of Christ's pre-existence by describing him as one "who was in the form of God." The relative pronoun hos, "who", which begins the verse links and identifies the historical Jesus with the divine Christ who existed prior to the incarnation.

The Greek transliterated form is morphe. The exact meaning of morphe is difficult to find. This term is found only here in Pauline epistles and this makes it impossible to study it together with its parallels. Recent scholarship suggests at least five meanings to the word. ${ }^{164}$ First, morphe can be understood as "the essential nature and character of God." Second, morphē has been understood as eikōn

\footnotetext{
${ }^{162}$ Hellerman, as cited by Gorman, Inhabiting the Cruciform God, 17.

${ }^{163}$ Gorman, Inhabiting the Cruciform God, 17. (italics not ours)

${ }^{164}$ Some of these views were gleaned from Dennis W. Jowers, "The Meaning of Morphe on Philippians 2:6-7" in JETS 49/4 (2006): 739-66.
} 
(image) of God, thus describing the first human being, Adam at his creation (Gen. 1:26,27). Another view regards morphe as the glory of God as in John 17:5. A fourth view is that morphe means form in the sense of shape, outward appearance or visible appearance. Lastly, morphē has been understood as the mode of being or a way of being. While all these views express at least a truth about Jesus in the Bible, not all of them can fit the present context.

A careful examination of morphe reveals that it signifies our Lord's divine attributes which compose his divine essence. "Form of God" has to do with attributes inherently characteristic of deity in Jesus Christ. Gifford notes: "morphe is therefore properly the nature or essence, not in the abstract, but as actually subsisting in the individual, and retained as long as the individual exists." ${ }^{165}$ Vincent observes as follows: "The word [morphē] is used in its philosophical sense, to denote that expression of being which carries in itself the distinctive nature and character of being to whom it pertains, and is thus permanently identified with that nature and character." 166 It has to do with the essence of a person or thing, in contrast to the noun schema (2:7), which refers to the outward appearance, which may be temporary or changeable. Paul used the term to give a description of the mode in which the essential being of God is expressed. This thought is in line with Peter O' Brien's assertion that morphe "refers to that form which truly and fully expresses the being which underlies it." 167 This means that morphe "does not refer simply to external appearance but pictures the preexistent Christ as clothed in the garments of divine majesty and splendor." 168

Even though the word "form" carries the idea of shape, it cannot be understood in that sense in the current context because God has no shape. Morphe is a concept of pure form. So, the 'form of God' in which the preexistent Christ existed is no mere form but the

\footnotetext{
${ }^{165}$ Gifford as cited by Peter Felter, Gethsemane "My Father, If It Is Possible, May This Cup be Taken from Me" (Np: Xulon Press, 2012), 338.

${ }^{166}$ Vincent, Word Studies III, 430.

${ }^{167}$ Peter O’ Brien, The Epistle to the Philippians (Grand Rapids: Eerdmans Publishing, 1991), 207.

${ }^{168}$ Ibid., 207-11.
} 
divine mode of being; similarly, the 'form of a servant' is the mode of being of a servant. If "morphe theou" implies anything less than fully God, then "morphe doulos" (v.7) must also imply that the Christ was something less than a servant while on earth. In order words, if the phrase, "form of a servant," truly indicates a true servanthood, then surely, "form of God" indicates true deity. Wuest makes the following comment,

Our Lord was in the form of God. The word "God" is without the definite article in the Greek text, and therefore refers to the divine essence. Thus, our Lord's outward expression of His inmost being was as to its nature the expression of the divine essence of Deity. Since that outward expression which this word 'form' speaks of, comes from and is truly representative of the inward being, it follows that our Lord as to His nature is the possessor of the divine essence Deity, and being that, it also necessarily follows that $\mathrm{He}$ is absolute Deity Himself, a co-participant with God the Father and God the Holy Spirit in that divine essence which constitutes God. ${ }^{169}$

Therefore, when Paul says, "Christ was in the form of God" he means Christ "had the very nature of God"; "possessed the nature of God"; "was divine by nature"; or "had always been God by nature". The expression morphe does not refer simply to external appearance but pictures the preexistent Christ as clothed in the garments of divine majesty and splendor. He was in the form of God, sharing God's glory.

In Greek, there are two separate words for "form." One refers to the essential nature and character of something, that is, the underlying reality which never changes. The other refers to an outward shape and appearance of something which may change due to change in circumstance. The former appears in v. 6 while the latter is used in v. 7. Paul used both terms in this hymn to set a sharp contrast between Christ's relationship to God and to humanity. "Form" stands in contrast with "likeness". "Form" (v.6) is intrinsic and essential quality, a quality of abiding and permanent worth or ${ }^{169}$ Vincent, Word Studies II, 63. 
that which indicates the interior nature, while "likeness" is accidental and outward, changeable and variable.

\section{His Choice (verse 6b, c)}

The participle hyparchion (rendered "though" NRSV or "being" NIV, in the sense of "existing" or "being present") is in the present tense, signifying Christ's continuing condition. The word, in the present context, points to Christ's possession of the essential nature of God from eternity. It significantly points to the fact that Jesus did not come into existence but that he was already in existence before his incarnation. Paul had the option to use the usual Greek word for "was" or "being." But he carefully chose this word hyparchion in order to stress the essence of a person's nature, his continuous state or condition.

Following Bockmuehl, Gorman proposes three ways of translating hyparchion. ${ }^{170}$ It can be understood concessively as "though" or "although" he was in the form of God; causally, "because" or "since" he was in the form of God; or temporally, and more neutrally as "being" in the form of God, or "while" he was in the form of God. Hyparchion is dependent on the main verb of the sentence, hègessato, a form of the verb "consider." In the present context, hyparchion is used concessively to contrast the existing reality of being in the form of God and the dramatic downward mobility of taking the form of a slave. However, the deeper structure of the text may also give support to causal use of the term. A study of the interrelated elements $[\mathrm{x}],[\mathrm{y}]$, and $[\mathrm{z}]$ in this and some other Pauline writings will give support to this position.

The "although $[\mathrm{x})$ not $[\mathrm{y})$ but $[\mathrm{z})$ " pattern shown in the present text corresponds to ["although [status) not [selfishness) but [selflessness)"]. This pattern has both Christological and apostolic use in Pauline writings. Gorman cites 1 Thess. 2:6-8 as an example. Here Paul depicts his behavior as "although $[\mathrm{x}]$ not [y] but $[\mathrm{z}]$ " when

\footnotetext{
${ }^{170}$ Gorman, Inhabiting the Cruciform God, 20.
} 
he writes, "although we $[\mathrm{x}]$ might have thrown our weight around as apostles, we did not [y] seek honor from humans, but we [z] were gentle among you and were pleased to share with you, not only the gospel, but our own selves." an apostle I was free, and I had the right to take a wife along with me and the right to be paid for my ministry, I did not [y] make use of any of these rights but rather [z] enslaved myself to all in multiple ways, including self-support and adaptability to different kinds of people" (1 Cor 9:1-23). ${ }^{172}$ Paul's point is that he forfeited his apostolic privileges in order to imitate Christ or conform to his standards (as he teaches in 1 Cor. 11:1); he did not take advantage of his position as an apostle for personal gain. Rather, like his self-emptying, crucified Lord, Paul an ambassador (2 Cor 5:20) acts "kenotically and cruciformly." The fact that Paul forfeited these rights does not in any way take from him his apostolic office or authority. He remained an apostle but refused to take advantage of that position to his own advantage.

The "[x]" in the pattern has at least two features. ${ }^{174}$ First of all, it refers to a status that is already possessed. Secondly, it refers to something that can be exploited either for selfish gain or not. True possession of "[x]" is demonstrated by the refusal by the possessor to "exploit it selfishly and thus to use it in such a selfless way that its use seems to be a renunciation of the status but is in fact a different-fromnormal manner of incarnating that status." 175 Having demonstrated how Paul applied the narrative pattern "although [x] not [y] but [z]" to his own narrative identity as an apostle, we can state with safety that Phil. 2:6 shows that Christ possessed the essence of God, the "not $[y]$ but $[z]$ " dimension that constitutes the " $[\mathrm{x}]$ " dimension. This means the possession of $[\mathrm{x}]$ is elucidated by the "not $[\mathrm{y}]$ but [z]" dimension. Therefore, Paul's true apostolic status (his [x]) is "most truly and fully exercised," not in throwing his weight around, taking advantage of the position to claim his right to financial support, using ${ }_{171}$ Ibid., 23.

${ }^{172}$ A paraphrased summary by Gorman, Inhabiting the Cruciform God, 23.

${ }^{173}$ Ibid., 24.

${ }^{174}$ Ibid.

${ }^{175}$ Ibid. 
his apostolic power to command others to serve him (his [y]), but in practicing selfless, "Christlike, parental love" (1 Thess. 2) and also enslaving himself by engaging in tent-making as a means of supporting himself financially instead of making himself a burden unto others (1 Cor. 9) (his [z]). ${ }^{176}$

Applying this pattern to Christ, his [x], his status of being "in the form of God" and hence possessing "equality with God", finds its true and full manifestation, not in exploiting that status for selfish gain ([y]), but in the self-emptying and self-humiliation manifested in the incarnation and crucifixion ([z]). ${ }^{177}$ Christ's act of self-emptying and self-humiliation belongs in character of his divine identity. Therefore, his condescension was not a contravention of his true identity. Christ did not act out of character, in an ungodlike manner and hence contrary in fact to true divine identity when he condescended. Rather, we must consider the condescension as the embodiment of his true identity. Christ, in his condescension, acted in character with his divine nature, in a way that is ungodlike but shocking to misguided human perceptions of divinity. Christ acted in a way contrary to our expectation for a divine being when he emptied and humbled himself. Christ's story sounds counterintuitive, abnormal, and absurd from the normal human perspective.

Paul confirms this position in his argument that Christ crucified is the counterintuitive reality of divine wisdom and power (1 Cor 1:18-25). The message of the cross is foolishness to normal human thinking because according to such thinking the Messiah cannot be crucified. Such an idea "subverts and even lampoons how millions within the Roman Empire took it for granted that somebody with the 'form of God' should act." 178 In the context of the Roman Empire, Phil 2:6-8 gives the counterintuitive kenotic and cruciform identity of God displayed in Christ. Here, like Phil. 2, Paul redefines God's essential attributes and divinity itself. He points out just as the cross displays God's wisdom and power, so also the very form of God is

\footnotetext{
${ }^{176}$ Ibid., 24-25.

${ }^{177}$ Ibid., 25.

${ }^{178}$ Crossan and Reed as cited by Gorman, Inhabiting the Cruciform God, 25.
} 
displayed by the self-emptying and self-humiliation act of God which climaxes in the crucifixion. ${ }^{179}$ The cross is theophanic in nature. Christ therefore did what he did because he was the true form of God. Gorman therefore contends that "at the deepest level the 'although' of v. 6 is in fact a "because." "' 180 This is the meaning we get from the deep structure of the text as against surface structure. In accordance with the deep structure the reason for Christ's self-emptying and selfhumiliation was that he was in the form of God and had equality with God. Since Christ's divinity is kenotic and cruciform in character, the expression "Although he was in the form of God" must be understood as "Because he was in the form of God." 181

The hymn continues to say that "he did not consider equality with God something to grasp" (v. 6b). The noun harpagmos (rendered "something to be grasped") has been interpreted variously. It can mean robbing in the active sense or a prize gained through robbery in the passive sense. It occurs only here in the NT, making it difficult to study other usage of the word. It derives from the noun harpago, meaning to "snatch, seize." Three possible interpretations have been outlined by Homer A. Kent Jr. ${ }^{182}$ : (1). Christ in his preincarnate state possessed equality with the Father but voluntarily decided not to cling to it. In other words, Christ did not consider his equality with God as something to take advantage of. (2). There was no need for Christ, who possessed equality with the Father, to grasp at that equality with the Father. (3). Christ, unlike Adam, wanted to wait till the appropriate time (after his suffering) before reaching for the crown. Thus, he refused to seize for his own glory that which belonged to God. The context of the text helps us to decide which interpretation is likely. The context reveals that Christ already was in the form of God and possessed equality with God. The second view expresses a truth but, again, the context (especially what follows) betrays its weakness. The third view, which places equality with God

\footnotetext{
${ }^{179}$ Gorman, Inhabiting the Cruciform God, 27.

${ }^{180}$ Ibid., 29.

${ }^{181}$ Ibid., 26.

${ }^{182}$ Gaebelein (ed.), The Expositor's Bible Commentary vol. 11, 123.
} 
in the futuristic sense, is unlikely. Yet, we may compare Adam and Christ in the sense that Adam wanted to snatch coequality with God in a false way, but Christ possessed this equality and took no advantage of it. Hoover contends that the idiomatic expression ouch harpagmon hègēsato to always "refers to something already present and at one's disposal [such that the issue is] not whether one possesses something, but whether or not one chooses to exploit something." "183 Granted that this contention is true, we can conclude that "Christ already was, in fact, equal with God." 184 This makes options 2 and 3 invalid.

The first view seems most appropriate in this case. It was a matter of choice; Christ was not compelled in any way to relinquish his glory that he had from the beginning. Christ therefore did not let equality with God prevent him from becoming and dying like a slave for our redemption. Christ could have taken advantage of his position of equality with God, but he did not; rather, he made himself nothing. In the words of Lewis and Demarest, "the eternal Christ chose not to regard existence-in-a-manner-of-equality-with God a treasure to be greedily hoarded. Instead he voluntarily stripped himself (ekenōsen) of his prerogatives as the divine Son (his God-equal position) by 'taking the very nature of a servant' (morphē doulou, v. 7) - namely, by assuming the form and exhibiting the condition of a common slave." ${ }^{185}$ F. F. Bruce's point is worthy of note:

There is no question of Christ trying to snatch or seize equality with God: that was already his because he always had the nature of God. Neither is there any question of his trying to retain it by force. The point is rather that he did not treat his equality with God as an excuse for self-assertion or self-aggrandizement; on the contrary, he treated it as an occasion for renouncing every advantage or privilege that might have accrued to him thereby, as an opportunity for selfimpoverishment and unreserved self-sacrifice. ${ }^{186}$

\footnotetext{
${ }^{183}$ Hoover, as cited by Gorman, Inhabiting the Cruciform God, 20.

${ }^{184}$ Gorman, Inhabiting the Cruciform God, 20.

${ }^{185}$ Demarest and Lewis, Integrative Theology vol. 2, 267.

${ }^{186}$ F.F. Bruce, Philippians (San Francisco: Harper \& Row, 1983), 45.
} 


\section{His Incarnation (verse 7a, b)}

This section deals with the incarnation and earthly humiliation of Christ. In 7-8 is a reference to Christ's two-step alternative to selfish exploitation of his equality with God, self-emptying and selfhumbling in the "narrative pattern." The two-step downward mobility comprises first, his voluntary self-emptying through the incarnation and second, his voluntary self-humbling and obedience that climaxed at the death on a cross. In v. 7, Paul begins to describe the incarnate state of Christ. He uses two main clauses to make his point: (1). but emptied himself, (literally meaning, "but himself emptied") and (2) he humbled himself (v. 8). The strong adversative, alla (but) contrasts v. 7 with what has gone before. Instead of taking advantage of his equality with God, he decided to make himself nothing. Rather than exploit his sovereignty he takes upon himself service. The emptying was self-imposed; no one forced him to come into the world and die for our sins.

In secular Greek, the verb kenoun literally means "to empty, make empty" and then metaphorically "to make of no effect." This verb has given rise to the kenotic theories of the incarnation (kenosis being the noun cognate to the verb kenoun) which probe the nature of Christ's "emptying" himself. Kenotic theories seek to answer the question, "Of what did Christ empty himself?"

The word labon translated "taking" ("taking the form of a slave") must be understood as an addition rather than an exchange. The form of God was not exchanged with the form of a slave. Rather, servanthood was added to divinity. He took upon himself servanthood (Is. 42:1; Ezek. 34:23; Zech. 3:8; Mark 10:45; Matt. 20:28; Luke $22: 27)$. Therefore, at the incarnation, Christ did not grasp equality with God but service to God and humankind.

The expression "form of a servant" refers to the "the innermost reality of Christ's condition as a servant - that [h]e became really and essentially the servant of [humankind]" ${ }^{187}$ In the Greco-Roman world

\footnotetext{
${ }^{187}$ Vincent, Word Studies III, 433.
} 
slaves were lowest members of society. Therefore, Christ surrendered his sovereign rights and became a slave, to belong to the class of the most humiliated humans. This confirms his statement that he came not "to be served, but to serve" (Matt. 20:28; Mark 10:45; cf., John 13). Gorman rightly notes that, "The parallel phrases 'form of God' and 'form of a slave' mean that to the extent that this one really took on the form of a slave, he also really was in the form of God." 188

\section{His Abasement (v. 7c-8)}

Paul now moves on to tell us how Jesus appeared in the estimation of human beings. He notes that Jesus was "made in the likeness of people" (v. 7c). The term homoiomati translated "likeness" does not connote exactness as does eikōn. Neither does it connote intrinsic form as does morphe. It suggests both similarity and difference. Likeness asserts similarity but denies sameness. Jesus was as human as any other human but was sinless unlike any other human (Heb. 4:15). Paul's point is that Christ became a genuine human but there were certain respects in which he was not totally like other humans. Paul views Christ only as he could appear to humankind, that is his real and complete likeness to humanity. The mystery of Christ's eternal nature could not be manifested to humankind. He was like human beings, but with reference to his whole self, he was like no human person because certain aspects of his personality (that is equality with God) did not dwell in other people. The expression "the form of a slave" is clearly an antithesis to "the form of God" (v.6).

The word schèmati rendered "appearance" signifies external appearance or points to that quality of a person or thing as recognized or discovered by others. It appears only twice in the NT, here and at 1 Cor. 7:31. Christ appeared externally in human form. It is rendered in ESV as "And being found in human form" "And being found in appearance as a man" (v. 8a, NIV). Such a statement implies that Christ was more than how he appeared to people. Outwardly he

\footnotetext{
${ }^{188}$ Gorman, Inhabiting the Cruciform God, 20.
} 
appeared as a human person, yet he was more than a mere human being.

The condescension of Christ also included his death on the cross. The incarnation is meaningless without the cross. At the cross the perfect sacrifice was made once for all. The death on the cross was the cruelest form of capital punishment in the GrecoRoman world. The Romans took over this form of punishment from the Phoenicians and Persians and reserved this kind of death for malefactors, foreigners and slaves. It is the climax of Christ's humiliation. From the perspective of the OT, one who died on the cross was considered to be under God's curse (cf. Deut. 21:23). The eternal Son of God was mocked, scorned, beaten, spat upon, falsely accused and crucified cruelly.

\section{His Exaltation (vv. 9-11)}

Having considered Christ descending down, down, down (6-8), Paul now considers how the Son ascends up to the highest place. Humiliation now turns into exaltation, and servanthood to Lordship. The exaltation has to do with the resumption, on the part of Christ, of his independent exercise of divine attributes. The expression, dio, "Therefore" (NRSV, NIV, ESV) or "For this reason" (HCSB, NASB) introduces the result of Christ's humiliation and obedience. It does not mean that God has promoted Jesus to a new status for divinity cannot be gained by some act. Christ's exaltation follows the spiritual principle, "whoever humbles himself will be exalted" (Matt. 18.4; 23, 12; Luke 14.11, 18.14; cf. 2 Cor. 11.7; Phil. 4.12). Jesus' selfabasement was the reason for his exaltation (cf. Luke 1:35, Rom 4:22, Acts 10:29). His incomparable self-humiliation leads to his super-exaltation. As a consequent of Christ's incarnation and death as God's suffering servant, the Father "highly exalted him" (v. 9a).

The Greek word hyperypsōsen, translated "highly exalted" also means "superexalted" 189 or "hyperexalted." It occurs only here

\footnotetext{
${ }^{189}$ Gaebelein (ed.), The Expositor's Bible Commentary vol. 11, 124.
} 
in the NT. In the exaltation, all that he laid aside in the condescension is restored to the fullest. The point is not that God exalted Christ to a position higher than what he had before (the incarnation) but that he exalted him to a position far higher than who he assumed during his earthly ministry. This position is supported by the fact that it has already been established from v. 6 that Christ was eternally equal with God. Also, the word hyper connotes a superlative or elative force rather than comparative. Paul therefore contrasts the lowest point of Christ's earthly role (servant-obedience-criminal death) with the highest heavenly glory accorded him (cf. Isa 52:13).

In addition to rank or status, Christ being elevated to the highest position and given the name above all names, (which is the primary focus in this text), Christ's superexaltion may include the resurrection and ascension (Acts 2.23-24, 33; Rom 1.4; Heb. 1.3). The exaltation, is the Father's vindication and approval of the son. The hyperypsōsen should not lead us to think that Christ's new rank is higher than his preexistent rank. The contrast of "super-exalted" is not with the original state but with the "absolute degradation." The exaltation serves not as divine reward for Christ's work but as God's public vindication and recognition of "Jesus' self-emptying and selfhumbling as the display of true divinity that he already had, and that makes the worship of Jesus as Lord (i.e., YHWH, the God of Israel) perfectly appropriate." 190

The question as to which name Christ has been given has been answered differently. Some commentators see the name as Jesus, others see it as Lord (or Yahweh). The former is supported by the context: "so that at the name of Jesus..." (10a). In this sense the name of Jesus took on a new significance after His exaltation. But the form Iesou can be taken as genitive or dative and can therefore be rendered as "at the name of Jesus" or "at the name Jesus." 191 The former seems more probable because the "name" in question was given to the Son after the exaltation (when Christ was already known

\footnotetext{
${ }^{190}$ Gorman, Inhabiting the Cruciform God, 30.

${ }^{191}$ Gaebelein (ed.), The Expositor's Bible Commentary vol. 11, 125.
} 
as Jesus). When taken as the former, it will mean "at the name that belongs to Jesus." This name is the Lord or Yahweh. The "name" is a new name and cannot be Jesus which was given to him at birth. The connection between Isaiah 45:23 and Philippians 2:10-11 also support this view. The context in Isaiah 45:23 is the proclamation of the unique greatness of the God of Israel and of the universal worship that would be paid to him. This agrees with the context of Phil. 2:1011.

We claim support from Acts 2:36 where Peter says, "Let all the house of Israel know assuredly that God has made him both Lord and Christ, this Jesus whom you crucified." Peter's point is that Jesus' lordship and Messiahship was bestowed on him at his exaltation. Jesus was the Messiah and Lord before his resurrection but he had not fulfilled Messianic mission until he had died for our sin and risen again. The lordship over the world was actualized through his death and resurrection by through the defeat of the power of darkness which hitherto held the world in its grip. The word "every" suggests that there will be universal acknowledgement of Christ's sovereignty, even by his enemies. This is done to the glory of the Father.

\section{Kenotic Theories}

In general, "kenoticism interprets the incarnation as the transformation of God into man, or the exchange of divinity for humanity." 192 Kenotic theology arose due to three major concerns. ${ }^{193}$ First, there was the desire to explain the nature of the person of Christ that made it possible for his full humanity to be expressed. Therefore, they sought to answer the question: in what sense is Christ truly human? The second point was the desire to understand how Christ was truly God. The question was: How can Christ be truly man and truly God at the same time? The third concern was the question of how many centres of consciousness did Christ have? If he was omniscient as God and

\footnotetext{
${ }^{192}$ George S. Hendry, "Christology," A Dictionary of Christian Theology, ed. Alan Richardson (London: SCM, 1969), 60.

${ }^{193}$ Elwell (ed.) Evangelical Dictionary of Theology, 651.
} 
limited as human, then he had two centres of consciousness and thus not like any other human being. The concerns led to various forms of kenotic theologies. These theologies however shared "a need to affirm Jesus' real, limited humanity and limited consciousness along with the affirmation that he is very God and very human."194 The broad spectrum of Kenoticism (kenotic Christology) can be put into two categories. The first view, which was championed by Thomasius ${ }^{195}$ and Delitzsch (both Germans) and Gore and Fairbairn (both English), contends that Christ emptied himself of the "relative" divine attributes such as omnipotence, omnipresence, omniscience, but retained the "essential attributes" of holiness, love and righteousness"196

According to this view, it was impossible for Christ to live a truly human life without divesting himself of the so-called relative attributes. It is further contended that during his earthly life Christ limited himself to only human consciousness. Advocates of this view find support from passages such as John 17:5 which makes it clear that Christ in his earthly ministry did not possess the eternal glory he had with the Father; and Mark 13:32 which seems to suggest that Christ did not know the date for his Parousia; Matt. 28:18 which suggests that Christ's power over all things was given to him only after the resurrection and Eph. 4:10 which limits Christ's presence only to the earth.

The second view was expressed by Gess, Godet, Clarke, and Mackintosh. They argued that the pre-existent Logos emptied himself of both essential and relative attributes of God. ${ }^{197}$ According to this view, there was an actual transmutation of the Logos into a human soul. It denies that Christ was both God and human at the same time. Initially Christ had no consciousness of his divinity and did not have the mutual indwelling of the Father and the Holy Spirit. This position takes the incarnation as the change from divinity to humanity, not

\footnotetext{
${ }^{194}$ Elwell (ed.) Evangelical Dictionary of Theology, 651

${ }^{195}$ Gottfried Thomasius (1802-75) can be regarded as the father of modern kenotic theory. See Elwell (ed.) Evangelical Dictionary of Theology, 651.

${ }^{196}$ Wiley and Culberson, Introduction to Christian Theology, 207-8. See also Demarest and Lewis, Integrative Theology vol. 2, 252.

197 Wiley and Culberson, Introduction to Christian Theology, 208.
} 
addition of humanity to divinity. The incarnation is not "two natures or two opposite modes of being coexisting in the same subject, but a single subject passing from one mode of being to another."' 198

Orthodox Christianity rejects any of these kenotic views because they tend to teach that the incarnation led to a change in the divine nature of the Logos, and therefore he ceased to be God after the incarnation. If he surrendered any of his divine attributes such as omnipotence, omnipresence, omniscience etc., he could not have been described as all-knowing. If he ceased to be God while on earth he could not have said he and the Father are one (John 10:30). Jesus' statement that whoever saw him saw the Father (John 14:9) makes kenoticism unscriptural. While on earth in human form Jesus claimed to be God (Mark 2:10; John 8:58; 10:35-36; John 17:1-6), accepted the attribution of deity given him by others (Matt. 16:16; John 20:28), and worship due only to God (Matt. 28:17; John 9:38). His supernatural knowledge was demonstrated in his encounter with Nathaniel (John 1:48), the woman of Samaria (John 4:18-19). The fact that he knew about his betrayer in advance (John 6:64), about the location of fish (Luke 5:4-9), about "all that would befall him" in Jerusalem (John 18:4), about Lazarus's death before He was told (John 11:14), of His crucifixion and resurrection before it occurred (Mark 8:31; 9:31) also point to his supernatural knowledge.

To conclude, it must be noted that Christ in the incarnation did not exchange the form of God for the form of a slave, but rather manifested the form of God in the form of a slave. ${ }^{199}$ This understanding notwithstanding, we are still faced with the question, "Of what did Christ empty himself?"

\section{The Authors' position on What Christ emptied Himself of}

The context of 2:7 provides the best solution to the kenotic problem.

\footnotetext{
${ }^{198}$ Frederick L. Godet, Commentary on the Gospel of John, 3 vols. (Grand Rapids: Zondervan, reprint, 1969), 1:270.

${ }^{199}$ Grudem, Systematic Theology, 550.
} 
The main thesis of chapter 2 is to persuade the Philippians to "do nothing from selfishness or conceit, but in humility count others better than yourselves" (Phil. 2:3). Persuading them to put other people's interest first and humble themselves, Paul says "Let the same mind be in you that was in Christ Jesus, who, though he was in the form of God, did not regard equality with God as something to be exploited, but emptied himself, taking the form of a slave, being born in human likeness" (2:5-7, our emphasis). Now, to say that Christ emptied himself of his essential divine attributes will mean that Paul is asking the Philippians to imitate Christ by giving up some attributes or qualities such as intelligence, strength, skill etc. in order to be humble and have the mind of Christ. Such a conclusion which flows from the kenotic theories is ridiculous. To be sure, the Incarnation was not the subtraction of deity but rather the addition of humanity.

The verb "to empty" is used metaphorically/figuratively in four other passages (Rom 4:14; 1 Cor 1:17; 9:15; 2 Cor 9:3) in the sense of "to bring to nothing," "to make worthless," or "to empty of significance." In the present context the verb "to empty" is used as a metaphor for total self-abandonment and self-giving, referring back to what immediately precedes and its action is explained by the words which immediately follow. What is clear is that Christ did not hold onto his privileges, but gave up his divine rank by taking on the nature of a servant.

From the text, we are not told what exactly Christ emptied himself of. However, Paul uses at least four phrases to explain what he means by self-emptying: (1). taking the form of a slave, (2). being born in human likeness, (3). being found in human form, (4). he humbled himself and became obedient to the point of death- even death on a cross. These statements are also indicative of the fact that Christ became truly human.

We are therefore to understand the self-emptying as follows: The pre-existent logos gave up his divine glory which he had with the Father before the world was created. Thus, the incarnation of 
the pre-existent logos is nothing short of the divine logos' voluntary self-humiliation from his exalted position. This is evident also in his priestly prayer in John 17:5 (cf. 2 Cor. 8:9). This glory includes the praises in heaven, his position in heaven and his divine privileges in heaven. He gave up this glory in the incarnation to receive it back when he returned to heaven. This means that while the incarnation was a permanent act, the self-emptying was only temporal.

During his earthly life he became completely subordinate to the mediatorial will of the Father in all things, voluntarily offering himself in obedience to the Father's will. Not only did he become human, he also became the lowliest of humans and accepted death, even death on the cross, which was the most humiliating of all deaths at the time.

During his earthly ministry, he was under the immediate control of the Holy Spirit, who prepared for him a body, who gave him instructions, who anointed him for his Messianic mission and enabled him to offer himself as a pure sacrifice. The Holy Spirit empowered Jesus to face and overcome the devil's temptations according to the Synoptic gospels (Matt. 4:1; Mark 1:12; Luke 4:1-2). Luke further notes that the Holy Spirit descended upon Jesus during his baptism (Luke 3:21-22) and anointed him for ministry (Luke 4:18-19).

The following scenarios may illustrate the self-emptying of Christ. The first scenario is about ex-President J. J. Rawlings. He used to take part in sanitation programmes such as clearing of gutters. In taking part of this lowly work Mr. Rawlings did not cease to be president though he gave up his glory as a president. The second scenario is this. In Ghana, chiefs, traditional heads of traditional societies, dress flamboyantly. Most southern chiefs dress in Kente, with gold jewelries around their neck, wrist and head-gear. They sit in palanquins carried by their subjects and are followed by large crowds when attending programmes. Other regalia of the Ghanaian chief include umbrellas, and linguist-sticks or staffs of office. All these make the chief glorious-looking. Let us assume that one day a man 
falls into a deep pit and is not able to come out due to injury and lack of strength. For him to be rescued someone must enter the pit using the alternating slits that go all the way down the deep well, and then climb back up. Assuming further that no one can enter the pit except the chief of that village. The chief comes to the pit in his splendour and sympathises with the helpless man. To help him, by entering the pit and bringing him up, the chief lays aside his headdress and his robe, goes all the way to the bottom of the pit, carries the helpless man at his back, and brings him to safety. The chief does not cease to be chief when he laid his glory aside and went down to bring the man. What he laid aside, his kingly glory, does not in any way amount to his abdication of the throne.

In the same way Christ laid aside His heavenly glory, like the chief did, in order to save us. Just as the chief did not cease to be chief, Jesus did not cease to be God upon laying aside his divine glory. The picture is depicted in John as follows: Christ laid aside His robe, took a towel, and tied it around Himself. Next, he poured water into a basin and began to wash His disciples' feet and to dry them with the towel tied around him (John 13:4-5).

If so, then the statement, "he emptied Himself of all but love" in Charles Wesley's great hymn "And Can It Be" (Methodist Hymn numbered 371) presents a challenge. This statement implies that Jesus emptied himself of all attributes but love. But as we have contended above, Jesus did not empty himself of his divine attributes; he did not cease to be God. Perhaps, we can deal with this challenge by singing, "He emptied himself in humble love." In this case what he emptied himself of is not stated but the manner of self-emptying is stated as "in humble love." The Philippian text we are dealing with supports such view. That will save us the trouble of teaching that Christ, in the incarnation, emptied himself of any divine attribute.

\section{Conclusion}

This study has explored aspects of the Christology of Philippians 
2:6-11. We contended that both the concessive ("although") and the causative ("because") interpretations of the participle hyparchion ("being") in Phil 2:6 are theologically correct. The study also argued that just as humanity is inherent in human being so is divinity also Christ's inherent attribute. During the incarnation, Christ did not surrender the attributes of omnipresence, omnipotence, and omniscience, but heavenly glory and privileges. The study also made the point that the incarnation is consistent with God's nature. Therefore, the incarnation should not be regarded as ungodlike character of Christ.

\section{Review Exercise}

1. Critically examine the historical context of Philippians 2:611.

2. To what extent can we say Philippians 2:6-11 is an ancient Christian hymn?

3. Of what did Christ empty himself according to Philippians 2?

4. Critically assess the two main schools of kenotic theology.

5. What is the main Christology propounded by Paul in Philippians 2? 


\section{CHAPTER SIX \\ FIRSTBORN CHRISTOLOGY \\ (COLOSSIANS 1:15-20)}

Paul's designation of Jesus Christ as prototokos pases ktisis, first born (source) of all creation (Col. 1:15), has been very central in Christological discussions. The key issue has been the Christological message embedded in this expression. Should the expression be understood as "first to be created" as propounded by the Jehovah Witnesses (JWs)? This study investigates this question through an exegetical analysis of Col. 1:15-20. At the end, the study found that the Christology of prototokos pases ktisis points to the supremacy or pre-eminence rather than teach being first-created.

\section{Study Background}

The JWs differ from mainstream Christianity on many doctrinal issues, Christology being a prominent one. According to Christology of the JWs, Jesus is the first of all creations. Having made him as his first creation, God then used his firstborn Son as his instrument to create all other things, whether visible or invisible. Therefore, rather than being God, Jesus, they argue is a perfect human being who existed before his earthly life as a spirit creature - that is, Michael the archangel — and became the Messiah at his baptism. "Being the only begotten Son of God...the Word would be the prince among all other creatures. In this office, he [Christ] bore another name in heaven, which is 'Michael."' ${ }^{\prime 200}$

\footnotetext{
${ }^{200}$ See Walther Martin, The Kingdom of the Cults (Minneapolis: Bethany publishers, 2003), 79.
} 
Accordingly, even though the Son may be said to be like the Father or similar to the Father in his nature, he is not of the same substance as the Father, they conclude. Such a theology offers no room to regard Jesus as co-eternal or co-equal with the Father. It subordinates Christ to the Father: "The Bible shows that there is only one God...greater than the Son.... and that the Son, as the Firstborn, Only-begotten, and the 'creation of God,' had a beginning. That the Father is greater and older than the Son is reasonable, easy to

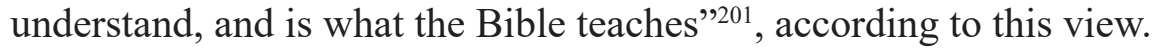

Paul's designation of Christ as prototokos pases ktisis, firstborn of all creation (Col. 1:15) is often used to support the above position. From this verse, the JWs claim that the title "firstborn" indicates that Christ is "the first being created by God", or simply put "first created." They further strengthen their position by claiming support from passages like John 1:18, John 3:16, John 3:18 and 1 John 4:9. The reference to Jesus as the "Only begotten Son of the Father" in these verses has been taken as implying that the Son was brought into existence by his Father in some time back. It is argued: If Jesus is the Son of God how can he be as old as the Father? If he is a son does it not mean that his existence has a starting point, and hence he cannot be eternal like the father? This position was first propelled by an Alexandrian presbyter named Arius in 319 AD. He argued that the Son was not of the same substance with the Father, but was rather created by the Father before the beginning of the world. The early church battled with the issue and finally declared him a heretic. The JWs revived this position through their publications.

This view has not been left unchecked. Murray J. Harris has refuted it saying "if [the writer] had believed that Jesus was first of God's creatures to be formed, the adjective protoktistos or prototogonos ('created first') or protoplastos ('formed first') might have been expected instead of prototokos." ${ }^{202}$ Hodge also holds that,

\footnotetext{
${ }^{201}$ John J. Davis, From Paradise Lost to Paradise Regained (Brooklyn: Watchtower Bible and Tract Society, 1958), 47.

${ }^{202}$ Murray J. Harris, Exegetical Guide to the Greek New Testament: Colossians and Philemon, second edition (Nashville: B \& H, 2010), 40.
} 
"The Apostle proves that Christ is the image of the invisible God, and ... the firstborn of all creation by an argument which proves that $\mathrm{He}$ cannot be a creature; and therefore the birth of which he speaks must be before time. ${ }^{" 203}$ Athanasius opined that Paul designated the Son as the "firstborn of creation" to show that he was not a creature: "for it would be inconsistent with His deity for him to be called a creature. For all things were created by the Father through the Son, but the Son alone was eternally begotten from the Father, whence God the Word is "firstborn of all creation." 204

Mainstream Christians uphold the traditional understandings propounded by the church Fathers which consider the expression "firstborn of all creation" as establishing Christ's supremacy or preeminence over all things. The supremacy of the Son over all creation is supported by many Biblical passages including Rom. 14:9 (Christ is the Lord both of the dead and of the living), 1 Cor. 15:27-28 and Eph. 1:22 (all things are subject under Christ's feet), Phil. 2:10 (at the name of Jesus every knee shall bend), 3:21 (subject all things to himself [Jesus]), Heb. 1:2 (He is heir of all things) among others.

The JWs interpretation disagrees with many passages of the NT. There are testimonies from other parts of the NT that Christ is not a created being. For example, in John 1:1 the Son is described as pre-existent, eternal, coequal and co-substantial with the Father. In John 1:3 the Son is said to be the one through whom all things, without exception, were made. The author of Hebrews refers to Christ as God's firstborn (1:6). If firstborn is taken to mean the first to be created then the Son cannot be God. Yet, in vs. 8 the pronoun "he" refers to the Son as God. In v. 10 the Father describes the Son as the Creator of the heavens and the earth. These and other verses in Scripture oppose the idea that Jesus is a creature.

This chapter purposes to determine the Christology of the expression prototokos pases ktisis. It is outlined as follows: OT usage ${ }^{203}$ Hodge, Systematic Theology I, 387.

${ }^{204}$ Lucy Trahan, 'Is there Scriptural Legitimacy for Jehovah's Witnesses Christology of the 'Firstborn' as First of God's Created Being?" (Unpublished Master of Arts in Theological Studies thesis:

Concordia University, 2012), 65. 
of the term firstborn is discussed to show the different meanings it assumed before the NT era. Next, the historical background of the letter to the Colossians is discussed in order to appreciate the political, socio-economic and religious situations in which the book was written. The final part of the study deals with the exegetical study of Col. 1:15-18 to determine the best meaning of the phrase in question within its immediate context. At the end, the study concludes that the Christology of prototokos pases ktisis is that of supremacy or preeminence rather than first-creation.

\section{Old Testament Usage of "Firstborn"}

The meaning of the phrase "firstborn" in Colossians 1:15 is perhaps impossible (or at least difficult) to determine without an accurate understanding of OT usage and implications. In the OT are a variety of Hebrew words formed from the b-k-r stem which stands for "first." For example, the masculine noun bekhor means "firstborn son", the feminine word bekirah means "firstborn or older daughter", bekhorah means "birthright". There are other words which refer to the concept of the "firstborn" but are not from the b-k-r stem. The word peter commonly refers to "that which first opens", another way of saying "firstborn". It combines with rechem to mean "that which first opens the womb." In this sense, the term "firstborn" simply means "to be born first" or "first to be born", whether human or animals ${ }^{205}$ (cf. Gen. 4:4; Ex. 1312b, 13, 15; 34:19ff.; 11:5; 12:12; Num. 18:15 etc.). A peculiar sanctity was attached to the first-born both of human and of cattle. God claimed that the first-born males of humans and of animals should be consecrated to him. The first-fruits of the ground were offered to God just as the first-born of humans and animals (Exod. 22:28-30; 34:19-20; Num. 18:15 ff. [cf. Lk. 2:23 ff.] etc.).

Beside its use in a sense of "first to open the womb" or "first to be born", bekhor may be used in the sense of having the greatest position, dignity, and honor (see Esau in Gen. 25:29 ff; 49:3; 2 Chron. ${ }^{205}$ Ronald F. Youngblood (ed), Nelson's New Illustrated Bible Dictionary (Nashville: Thomas Nelson, 1995), 452. 
21:3). When Esau came to his father Isaac to receive the blessing that was due him, he pleaded the fact that he was Isaac's firstborn-his prototokos (Gen. 27:32, LXX). Jacob, the second born son, had already deceived his father and received the blessing intended for Esau. This does not mean that Jacob from hence became older than Esau. Rather, he was accorded the honour due Esau who was the first born. The writer of Hebrew confirms this point when he accords Esau with his firstborn status or birth right (Heb. 12:16). Another example is found in Gen. 49:3 where Jacob said of Reuben "you are my firstborn, my might, the first sign of my strength, excelling in honour, excelling in power." Here, the dominant thought is not priority in birth but dignity, honour, strength and primogeniture. Firstborn in this sense refers to one who is chief or who is highly distinguished and pre-eminent.

In the Mosaic Law, the term "firstborn" is used regarding the specific rights and obligations/responsibilities of the first male child of a family. A socio-legal right was assigned to the firstborn in relation to the paternal inheritance since the father's firstborn son would be destined to inherit a double portion of his family's wealth (Deut. 21:17). Since the firstborn male was expected to inherit the father's might to a greater extent than offspring who followed, he was also in a better position to take up his father's responsibilities when the time came to take over the affairs of the household. Thus, the firstborn had the right of leadership or authority in his generation. He also acquired a special blessing, replaced his father as the head of family and therefore possessed authority over the younger siblings.

The OT also gives evidence of situations where a younger son was made the heir instead of the firstborn son. ${ }^{206}$ This usually happened if the first male child proved incompetent or underserving. Abraham chose Isaac as heir rather than Ismael who was the firstborn (Gen. 27). This is also seen in the life of Reuben who, though was born first, forfeited his firstborn right because he defiled his father's bed. The effect was not a transfer of his priority in time but a passing on of the dominion belonging to him (his family) to Judah and the

\footnotetext{
${ }^{206}$ Youngblood (ed), Nelson's New Illustrated Bible Dictionary, 452.
} 
double portion to Joseph (Gen. 48:20-22, 1 Chr. 5:1-2). His birth right was given to the sons of Joseph so that his name is not mentioned in the genealogy according to birth right. The right of primogeniture was "a persistent and widespread institution whose legal, social, and religious features were reflected in the norms of ancient Israelite society." ${ }^{207}$ This assertion underscores the fact that the firstborn had a special status not only in respect to inheritance but also to cultic rules.

Yahweh's reference to Israel as his firstborn (Ex. 4:22; cf. Jer. 31:9) has no biological connotation. Clearly, here the word firstborn has nothing to do with precedence in time, but rather precedence in rank among the nations, as God views their relative importance. God used this designation to indicate that he had selected Israel as heir by election or adoption. It is obvious that firstborn does not suggest that all the nations are God's sons and Israel is a brother to them. ${ }^{208}$ Rather, it signifies that Israel had special privileges (for example being the sole object of God's special love) which the other nations did not have.

The literal and figurative use of "firstborn" are both present in the statement, "And you shall say to Pharaoh, thus says Yahweh, Israel is my son, my firstborn: and I have said to you, Let my son go, that he may serve me; and you have refused to let him go: behold, I will slay your son, your firstborn" (Ex. 4:22-23). In the description of Israel as God's firstborn, the word is used in the sense of someone considered great by God, (having been chosen by God), while in the phrase, "thy son, thy first-born," the word is used in its ordinary literal sense [born first].

The last example to give is God's promise to David to make him "the first-born, the highest of the kings of the earth" (Ps. 89:27). This foremost position as king of kings is a matter of appointment, not of time of birth. This promise is not intended to mean that David

${ }^{207}$ As cited in Carol Lowery Delaney, Abraham on Trial: The Social Legacy of Biblical Myth (Princeton: Princeton University Press, 1998), 93.

${ }^{208}$ See H. Wayne House, "The Doctrine of Christ in Colossians" in Bibliotheca Sacra 149 (April 1992) 180-192: 181 . 
was the first king to be born physically. Neither did it mean he is the firstborn in his family, David was rather the youngest (1 Sam. 16:11). Rather, David was to be made the firstborn king in the sense that he was to be the highest, the pre-eminent of the kings of the earth or one who occupies the highest position on earth. This prophecy has everything to do with David's greater Son, the great Messianic King, who is also given the same title.

The foregoing points out the single truth that in the OT "firstborn" is a designation signifying the idea of highest position or authority over others; it is not a mere word indicating the time of a biological birth. To take "firstborn" as meaning just "first" to be born, or the "first" in time betrays an incredibly poor understanding of how the word has been used in the Bible.

\section{Background to the Epistle to the Colossians}

Colossae was one of the cities of the beautiful Lycus Valley in Phrygia, situated a short distance from Laodicea and Hierapolis. ${ }^{209}$ The church of Colossae began during Paul's three-year pastoral ministry in Ephesus. Epaphras returned home to Colossae and started the church there (1:7). The city of Colossae was inhabited by both Gentiles and Jews. Colossae's population of Jewish and Gentile people manifested itself in the membership of the church and in the Jewish and Gentile heresies that plagued the local church.

Despite the internal evidence of Pauline authorship (1:1), the characteristic Pauline line of thought developed in it and the Pauline style evident in it, the authorship of Colossians has been debated. Three arguments have been advanced against Pauline authorship. ${ }^{210}$ First, the style seems different from that of the apostle. Second, the heresy combated in this Epistle shows clear traces of second century Gnosticism. Third, the Christology of this Epistle is un-Pauline.

\footnotetext{
${ }^{209}$ Donald Guthrie, New Testament Introduction (Illinois: Inter-varsity Press, 1974), 545.

${ }^{210}$ Louis Berkhof, Introduction to the New Testament (Grand Rapids, MI: Christian Classics Ethereal Library, 2004), 114.
} 
Raymond E. Brown has discovered that approximately 60 percent of critical biblical scholarship hold on to a non-Pauline authorship of Colossians. ${ }^{211} \mathrm{He}$ outlines two different ideas of pseudonymity in relation to Colossians. First, there is the view that it was written by one of Paul's close associates during his lifetime or shortly after his death, perhaps with an idea of what Paul himself wanted to write. ${ }^{212}$ In this case, "Colossians reflects the voice of Paul rather than the actual words of Paul." 213 Second is the belief that this letter was written years after Paul's death by a student of Paul who takes upon himself Paul's mantle and speaks to a situation that has only now developed. ${ }^{214}$ Considering the weight of each side of the argument, the current writers contend for a Pauline authorship. Besides internal evidence which supports this position, the similarities between Colossians and the undisputed Pauline epistles exceed their differences. The differences, in our view, reflect a fresh response to a newly encountered heresy. "Colossians thus reveals Paul extending his theology in new directions." 215

The letter to the Colossians was occasioned by the infiltration of the church with heresies coming both from Jews and Gentiles. ${ }^{216}$ Jewish Christians, based on their Judaism background, insisted on the observance of certain aspects of Jewish legalism which included physical circumcision as a prerequisite for salvation, observation of the ceremonial rituals of the OT law and rigid asceticism. They held the opinion that belief in Christ alone was not sufficient for salvation. The Gentiles, on the other hand, embraced pagan mysticism, and certain beliefs which resulted in an early form of Gnosticism, an eclectic phenomenon that includes the belief that flesh is evil but spirit is good.

\footnotetext{
${ }^{211}$ Raymond E. Brown, An Introduction to The New Testament (New York: Doubleday, 1997), 610.

${ }^{212}$ Brown, Introduction to the New Testament, 610; see also Carl R. Holladay, A Critical Introduction to the New Testament: Interpreting the Message and Meaning of Jesus Christ (Nashville: Abingdon Press, 2005), 555.-557.

${ }^{213}$ Holladay, New Testament, 557.

${ }^{214}$ Brown, New Testament, 610.

${ }^{215}$ Holladay, New Testament, 555.

${ }^{216}$ Berkhof, New Testament, 116.
} 
In addition, was the practice of the worship of angels. Possibly angels in mediating roles were thought to give access to Christ, who may have been regarded as a member, or even the archangel, of the angelic hierarchy. This belief is found in African Traditional Religions, which hold that God cannot be approached directly and so must be approached through a series of hierarchical spirits. Various Jewish texts during the Hellenistic-Roman period reflect this common belief. ${ }^{217}$ The church became syncretistic, combining different, often contradictory beliefs, while blending practices of various schools of thought into their beliefs.

Paul, while imprisoned probably in Rome (60-62 CE), heard through Epaphras that the stability of the church was threatened by some syncretistic false teachings. ${ }^{218}$ Paul's response to the issue led to the writing of this letter. He therefore wrote this epistle with the purpose of correcting the Colossian heresy. To demolish the idea of the need for righteousness through observance of law and belief in angels, Paul "clearly sets forth the unique significance of Christ, and the all-sufficient character of his redemption." ${ }^{119}$ Paul wrote this epistle together with the epistles to the Ephesians, Philippians and Philemon from prison. The epistle to the Colossians was sent to the Colossian church through Tychicus.

\section{Literary Context}

The book begins with the usual salutation, common to nearly all of Pauline epistles: (1) an identification of the writer, or writers of the letter; (2) the recipients; and (3) a Christian salutation. He thanks God for their lives and commends them for their faith in God. Just before the section under consideration Paul talks about how Christians have been transferred from the kingdom of darkness to God's kingdom. He then proceeds to insert the hymn recorded in vv. 15-20. This section

\footnotetext{
${ }^{217}$ Holladay, New Testament, 559.

${ }^{218}$ See Douglas J. Moo, "The Letters to the Colossians and to Philemon" in PNTC (Grand Rapids: Eerdmans, 2008), 26-46; Berkhof, New Testament, 116.

${ }^{219}$ Berkhof, New Testament, 116.
} 
has been regarded as an early (pre-Pauline) Christian hymn. It was inserted in the letter to emphasize the pre-eminence of Christ. Much has been made of strophes, stanzas, chiasmus, and more features that would seem to indicate some liturgical form to the passage. Three main strophes have been proposed: first strophe vv. 15-16, second strophe 17-18a and third strophe $18 \mathrm{~b}-20 .{ }^{220}$ The main themes in this passage include Christ's relation to creation and to the Church.

\section{Greek Text}

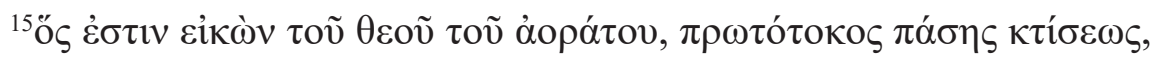

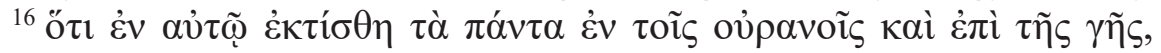

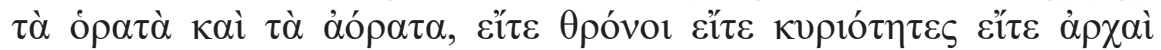

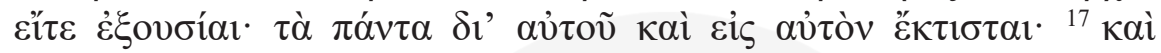

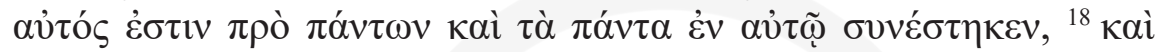

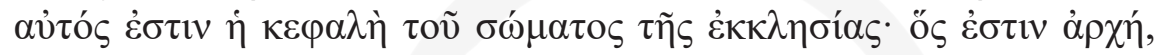

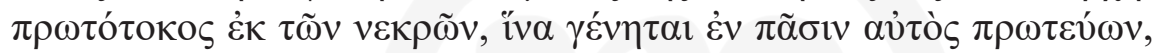

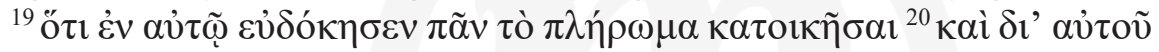

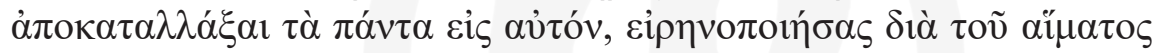

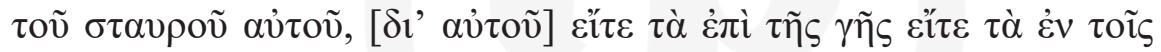
oủpavoĩ

\section{Colossians 1:15-20}

hos estin eikōn tou Theou tou aoratou, prōtotokos pasēs ktiseōs, hoti en autō ektisthē ta panta en tois ouranois kai epi tēs gēs, ta horata kai ta aorata, eite thronoi eite kyriotētes eite archai eite exousiai; ta panta di' autou kai eis auton ektistai;

kai autos estin pro pantōn kai ta panta en autō synestēken, kai autos estin hē kephalē tou sōmatos, tēs ekklēsias; hos estin archē, prōtotokos ek tōn nekrōn, hina genētai en pasin autos prōteuōn,

${ }^{220}$ See Asante, Jesus the Christ, 43. 
hoti en autō eudokēsen pan to plērōma katoikēsai

kai di' autou apokatallaxai ta panta eis auton, eirēnopoiēsas dia tou haimatos tou staurou autou, di' autou eite ta epi tēs gēs eite ta en tois ouranois.

\section{Translation $^{221}$}

${ }^{15} \mathrm{He}$ is the image of the invisible God, the firstborn over all creation; ${ }^{16}$ for by him all things in heaven and on earth were created, things visible and invisible, whether thrones or dominions or rulers or powers - all things have been created through him and for him. ${ }^{17} \mathrm{He}$ himself is before all things, and in him all things hold together. ${ }^{18} \mathrm{He}$ is the head of the body, the church; he is the beginning, the firstborn from the dead, so that he might come to have first place in everything. ${ }^{19}$ For in him all the fullness of God was pleased to dwell, ${ }^{20}$ and through him God was pleased to reconcile to himself all things, whether on earth or in heaven, by making peace through the blood of his cross.

\section{Close Reading of Colossians 1:15-20}

\section{Verse 15}

In verse 15 the person of Christ is described both in relation to deity and to creation. The Greek begins with the relative "who" which refers to Christ. It affirms that Christ is eikōn, the image, of the invisible God. The word "image" almost immediately brings to mind the Genesis narrative in which humans are made according to the image of God. Upon inspection, it is found that, indeed, the Septuagint (LXX) uses eikōn in both Gen. 1:26-28 and Gen. 5:1. In the New Testament, however, it takes on a new meaning, being used to describe the progressive sanctification of those who are in Christ.

Peter T. O'Brien contends that "As the first title of majesty,

${ }^{221}$ We found the NRSV translation very appropriate for this discussion and so we have adapted it with slight modification. 
"image" emphasizes Christ's relation to God. The term points to his revealing of the Father on the one hand and his pre-existence on the other-it is both functional and ontological." ${ }^{222}$ David E. Garland notes that in the popular philosophy of Paul's time, images and the actual were considered one in the same rather than separate and distinct from the actual. He writes: "in Greek philosophy...the image has a share in the reality that it reveals and may be said to be the reality." 223

Asante observes that the expression "...the glory of Christ who is the image (eikōn) of God" (2 Cor. 4:4) parallels the phraseology "the glory of God in the face of Christ" (2 Cor. 4:6). ${ }^{224}$ Asante quotes Grilmeier as stating, "the glory of Christ is none other than the glory of God which becomes visible in the face of Christ." ${ }^{225}$ Carroll and Mullins assert that "the word 'is' declares a permanent and abiding truth. Christ is in his essential nature the image of God."226

The term "the image" has two basic meaningsrepresentation and manifestation. ${ }^{227}$ In terms of representation, image refers to a symbol of the object pictured, perfect copy, essential embodiment, very substance, objectification or project. Image in the sense of manifestation means an appearance and connotes the idea of revealing something hidden. ${ }^{228}$ It is the outward manifestation of and illumination of something's inner core and essence. What this means is that in Christ the invisible God becomes visible to created beings. ${ }^{229}$ Thus, without Christ, God cannot be seen. In this verse eikon means the invisible, timeless nature and character of God perfectly_revealed, visible, understood. (see also John 1:18 2 ${ }^{222}$ Peter T. O'Brien, Word Biblical Commentary Volume 44: Colossians, Philemon (Waco, TX:

Word Books, 1982), 44.

${ }^{223}$ David E. Garland, The NIV Application Commentary: Colossians/Philemon (Grand Rapids, MI:

Zondervan, 1998), 87.

${ }^{224}$ Asante, Jesus the Christ, 44.

${ }^{225}$ Ibid.

${ }^{226}$ As cited in Daniel L. Akin (ed.), A Theology for the Church (Tennessee: B \& H Publishing Group, 2007), 501.

${ }^{227}$ H. Wayne House, "Doctrinal Issues in Colossians Part 2: The Doctrine of Christ in Colossians" in BSAC 149, no. 594 (1992), 181.

${ }_{228}$ Asante, Jesus the Christ, 45.

${ }^{229}$ Akin (ed.), Theology for the Church, 502. 
Cor. 4:4, 6 Heb. 1:3). Commenting on this text Calvin states that: (Paul) calls him the image of the invisible God, meaning by this, that it is in him alone that God, who is otherwise invisible, is manifested to us....Christ is called the image of God on this ground - that He makes God in a manner visible to us...We must, therefore, beware of seeking Him [God] elsewhere, for everything that would set itself off as a representation of God apart from Christ will be an idol. ${ }^{230}$

The nature and being of God are perfectly revealed in him. Like the head of a sovereign imprinted on a coin, so Christ is the "exact representation of [the Father's] being" (Heb. 1:3). For this reason, Christ could say that "Anyone who has seen me has seen the Father" (John 14:9). Anyone who has seen Christ, the visible manifestation of the invisible God, has therefore "seen" God indirectly (John 14:9). In Christ, we can see what God is like, his very nature and being.

In v. 15b, Paul refers to Christ as prototokos pases ktisis, the firstborn of all creation, the expression we investigated earlier. In Asante's view, the expression "firstborn of all creation" (Col. 1:15) has four possible meanings. ${ }^{231}$ First, it could mean the first to be created or first of a long succession of creatures. In this sense Christ is to be regarded as part of creation. The context itself does not admit the idea that Christ is a part of the created universe (see v. 16). Second, firstborn may indicate dignity and function. It has nothing to do with relation to time and so Christ is not regarded as part of creation. Third, the term could be interpreted in terms of genus or kind; that is in terms of type of all creation. The last possible interpretation is the right of primogeniture. In this sense, the expression means "all things belong to Christ." The expression "firstborn" has the nuance of supremacy and pre-eminence from the expressions that follow in vv. 16-17. As the firstborn, Christ enjoys absolute primacy over all creatures (comparative genitive) without exception. The expression indicates that "he existed before creation and actually participated

\footnotetext{
${ }^{230}$ Ibid., 501-2.

${ }^{231}$ Asante, Jesus the Christ, 45.
} 
in the creation process (John 1:3)." ${ }^{232}$ First-born in this context does not mean there were others who were likewise "born" after Christ. It should be understood as a term which stresses the position of Jesus as the heir of his heavenly Father. Christ's superiority to all creation may be expressed as "he is more important than all that was created" or "he ranks higher than the created order."

\section{Verse 16}

In v. 16, Christ is said to be the Creator of all things both visible and invisible. Paul would contradict himself if firstborn means first created in Col. 1:15. He begins with the preposition hoti, "for" or "because", as the proof of his supremacy. Afterwards he describes what it means to be "firstborn of all creation." The expression "in (en) him all things (ta panta) were created" could be interpreted instrumentally in the sense of an agent of creation or one by whom all things were created. It could also be interpreted locally in the sense of "putting the fact of creation with reference to its sphere and centre." 233

The expression ta panta, "all things" includes the totality of things in heaven and on earth, both visible and invisible. This is of utmost importance because it is a polemic to the false teaching that other spiritual beings, philosophies, and regulations should be relied upon to gain enlightenment and understanding. It "tacitly repudiates the notion of a fundamental division between the spiritual and the material." ${ }^{234}$ This means that matter and spirit both have divine origin. It insists that spiritual existences in any order, regardless of how exalted they are, are part of the things that "were created in Christ."

Three prepositional phrases set forth three aspects of Christ's relationship to creation in the text. First, en autou "by him" (v. 16a) refers to "in his mind" or "in his sphere of influence and responsibility." This means that the whole universe "is an unfolding

\footnotetext{
${ }^{232}$ Youngblood (ed), Bible Dictionary, 452.

${ }^{233}$ Marvin Vincent, Word Studies in the New Testament vol. 3 (Massachusetts: Hendrickson Publishers, 2009), 469.

${ }^{234}$ Buttrick et.al. (eds), The Interpreter's Bible vol. 11, 165.
} 
of the mind of God in Christ." 235 Jesus was the conditioning cause, originating centre and spiritual locality of God's creation. The one by whom all things were created, Christ himself must be uncreated, or else the statement is untrue.

The New World Translation (NWT) recognizes the challenge this fact poses to its Christology, and thus inserts the word "other" five times in verses 16-20. Col. 1:16-17 in NWT reads as follows: Because by means of him all [other] things were created ... All [other] things have been created through him and for him. Also, he is before all [other] things and by means of him all [other] things were made to exist." "Other" is placed in bracket because it is not part of the original text. By inserting the word "other" the JWs denied the Son of his deity and regard him as a created being through whom all things, with the exception of him, were created through him. No matter how hard the JWs try to rid Christ of his deity, the fact remains that the Son is not God's greatest creation through whom he created all other things but he is the Creator himself.

Secondly, dia autou, "by him" or "through him" (v. 16b) means he produced his idea with his power and his ability (cf. John 1:1ff and Heb. 1:1-3). It also means that creation came into being through Christ's mediation. Third, eis autou, "for him" (v. 16b) points to Christ as the end of the universe, the goal towards which all existence strives. ${ }^{236} \mathrm{He}$ is the purpose of creation. In this verse, the Lordship of Christ which finds expression in the designation "firstborn of all creation" is stressed.

\section{Verse 17}

This verse sums up the thought of vv. 15, 16 and completes the statement of Christ's relation to creation. The expression autos estin, "he is", counterparts the "I am" sayings in the Johannine gospel and points to an absolute pre-existence, implying Christ's deity. Pro panton, "before all things" signifies not only priority in time but also ${ }^{235}$ Ibid.

${ }^{236}$ Ibid., 167. 
"precedence of dignity", paving way for the idea of description of Christ as the "head" (kephalē) in v. 18 (see Col. 2:19) ${ }^{237}$ As one who existed before all things (cf. John 1:1), Christ is superior to creation and hence cannot be part of creation.

The expression sunesteken, "hold together", expresses the state of universe as an ordered and unified system. It points to the fact that Christ is both the unifying principle and the personal sustainer of all creation (cf. Heb. 1:3). The main thought is that the order and unity of creation are not accidental but derive from their vital relationship to Christ. In effect, all creation springs from him and finds in him its principle of cohesion. The entire fabric of all things created, whether seen or unseen, is continually upheld by Christ. All things fall under his power and authority, from before the beginning of all things, onwards and forever.

\section{Verse 18}

As Paul asserts that creation is maintained and upheld by Christ, he moves on to tell the Colossians that Christ is "the head of the body, the church," reminding them once again that they, along with all of creation, are under the supreme authority of Christ Jesus. Christ is the head of the ekklessia, Church in the sense that he is the mind which directs and the will which governs the life of the Church. The Church in this context refers to the universal or invisible one.

He moves on to say that Christ is the arche, beginning and the firstborn from the dead (cf. Rev. 1:15). The expression prototokos ek ton nekron, firstborn from the dead, carries the thought that Christ is the sovereign head of the whole new order. It also signifies the fact that Christ is first to rise from the dead with an immortal body (1 Cor. 15:20-22). This clause, in one sense, is a summary of all that Paul has affirmed from v. 15 to this point. Syntactically, however, it expresses the purpose of the immediate preceding context about Christ being the beginning, the firstborn from the dead. The purpose of Christ's resurrection from the dead is to show that he is pre-eminent in everything. 


\section{Verse 19}

The thesis of v. 19 is that in Christ we see the full essence of God. The word pleroma, rendered "fullness" is found 17 times in the NT, with four of its occurrences considered as parallel to the present text (Eph. 1:23; 3:19; 4:13; Col. 2:9). It is very probable that the word fullness was used by false teachers, who Paul confronts in his letter. Of what is Christ full? Different meanings have been assigned to this word. Calvin understood it as "fullness of righteousness, wisdom, power, and every blessing" because "whatever God has he has conferred upon his Son, as is said in John 5:20." 238 Peak like Meyer, Eddie, and Alfred argue that fullness means "the fullness of grace" (John 1:14). ${ }^{239}$ Other interpreters consider fullness as related to deity. "Fullness" means that all divine power and attributes of God were in Jesus. The fullness of who God is, in every respect, was in Christ during his earthly life and ministry. Christ lacks nothing of deity. He is pure deity; all that God is dwells in Christ. This view opposes any idea that Christ divested himself of his divine attributes through the incarnation.

Paul deliberately says "all" the fullness of God in order to make the point that the false teachers have erred in considering Christ as one of the supernatural intermediaries. For Paul, Christ is the one Mediator between God and the universe, the centre that holds the universe. The word katoikessai, rendered "fullness", suggests permanent residence in contrast to temporary sojourn. Paul uses this word, probably, to refute the false teaching that divine fullness resides temporarily in Christ.

\section{Verse 20}

In this verse Paul reveals Christ as God's agent in reconciling the world unto himself. The need for reconciliation implies an existing

\footnotetext{
${ }^{238}$ As cited in Frank E. Gaebelein (ed.), The Expositor's Bible Commentary vol. 11 (Grand Rapids, MI: Zondervan Publishing House, 1976), 185

${ }^{239}$ Ibid.
} 
state of alienation of the universe from God. As to how this alienation took place, we are not told here. From the wider context of Pauline writings, we see the cause of this alienation as $\sin$ (Paulalso refers to this as death, Rom.6:23). The reconciliatory act of God was necessitated by the fall of humanity. Until the death and resurrection of Christ there was no permanent solution to the problem of sin. Paul's point in this verse is that the Father was pleased (eudokesen) to reconcile (apokatallaxai) the world unto himself through the vicarious death of Christ on the Cross. The double compound apokatallaxai takes the place of katallaxai of earlier writings (e.g. Rom. 5:1, 2 Cor. 5:18ff) to signify that there was once a good relationship between God and the universe which was lost. The peace, erēnē, spoken about suggests the restoration of peace within the cosmos. Peace is made, eirēnopoiēsas through the blood of his cross. The blood of his cross signifies the sacrificial aspect of Christ's death.

\section{Conclusion}

This chapter has shown that there is no biblical support for interpreting "firstborn" as "first-created." The evidence is clear that the Bible is completely against the teaching that Christ is one of God's creations. The interpretation of "firstborn" as "first-created" must be rejected for at least, the following five reasons. ${ }^{240}$ Firstly, as noted earlier, the main purpose of the pericope and the entire book is to prove Christ's superiority over all things. Describing Christ as a creature defeats the purpose of the entire book. Secondly, there are other designations of Christ in the passage-for example, creator of all things (v. 16), sustainer of all things (v. 17) — that point to his priority and superiority over creation. Thirdly, the fact that the firstborn created "all things" (v. 16) points to the fact that he cannot be part of creation. Fourthly, the firstborn received worship of all the angels (Heb. 1:6) although creatures are not to receive worship (Exod. 20:4-5). Fifthly,

\footnotetext{
${ }^{240}$ The five reasons were gleaned from Norman L. Geisler, "Commentary on Colossians" in The Bible Knowledge Commentary edited by John F. Walvoord and Roy B. Zuck (Colorado: David C. Cook, 1983), 672 .
} 
the Greek word protoktisis, "first-created" would have been used instead of prototokos, firstborn, if Paul wanted to say that the Son is the first created being. In addition, this interpretation disagrees with many passages of the NT. There are testimonies from other parts of the NT pointing to the fact that Christ is not a created being (eg. John $1: 1,3)$.

We conclude then, that the term "firstborn" as applied to Christ in Colossians 1:15 signifies "both his priority to all creation (in time) and his sovereignty over all creation (in rank)." ${ }^{241}$ In other words, Christ is the firstborn of all creation in the sense that he precedes the whole creation and he is the supreme authority over all creation. The latter is betrayed in the NIV rendition "the firstborn over all creation" (Col. 1:15b, our emphasis). Thus, Colossians 1:15 means Christ is the source of all creation. Consequently, he has the privileges of authority and rule, the privileges belonging to the first born, but with respect to the whole creation of which he is not a part. This interpretation fits both the purpose of the book, the context of the passage and the entire theology of the Bible.

\section{Review Exercise}

1. Critically examine the OT concept of "firstborn."

2. What does it mean to say that "Christ is the image of the invisible God" (Col. 1:15a)?

3. React to the assertion that "Christ is the first creation through whom other things were created." Support your answer with biblical evidence.

4. How does Paul address the Colossian heresy in his epistle to the Colossians?

5. What Christological problems does Paul intend to solve in his epistle to the Colossians?

${ }^{241}$ Geisler, "Commentary on Colossians", 673. 


\section{CHAPTER 7 \\ PRIESTLY CHRISTOLOGY IN HEBREWS}

Throughout the NT, Christ's death on the cross is seen in sacrificial terms. The sacrificial death of Christ receives an incomparable emphasis in the epistle to the Hebrews, where the author links Christ's death to his priestly role. By referring to Christ as the great high priest, the author of Hebrews "introduces a new and exceedingly valuable picture into the Christian understanding of Christ's work." 242 The epistle also throws light on the relationship between the new and old covenants, the interpretation of the OT (especially, the Torah), and the subject of faith. Throughout his work, the author of Hebrews gives the OT sacrificial system a Christian meaning, closely linking it to the Christ event. In this study, we explore Priestly Christology as explicated in the epistle of Hebrews.

\section{Background to the Epistle to the Hebrews}

The author of the epistles to the Hebrews is not known. It is one of the two NT epistles that begin without a greeting mentioning the name of the author, the other one being 1 John. By the second century the epistle had been attributed to Paul. Both Clement ${ }^{243}$ and Pantaenus accepted it as Paul's work but Tertullian linked it to Barnabas. ${ }^{244}$ Clement opined that it was written in Hebrew for Hebrews but was translated into Greek by Luke. ${ }^{245}$ His contention was based on similarities between Hebrews and Acts (whose author is Luke). He further argued

\footnotetext{
${ }^{242}$ Leon Morris, The Cross in The New Testament (Grand Rapids, MI: W. B. Eerdmans Publishing Company, 1972), 284.

${ }^{243}$ Paul L. Maier, Eusebius. The Church History: A New Translation with Commentary (Grand Rapids, MI: Kregel Publications, 1999), 126.

${ }^{244}$ Buttrick (ed), The Interpreter's Bible vol. 11, 581; Berkhof, Introduction to the New Testament, 147.

${ }^{245}$ Maier, Eusebius. The Church History, 126. See also, Hodges, "Hebrews" in The Bible Knowledge Commentary, 777.
} 
that Paul did not introduce this letter with his usual greetings and identity because of the audience's prejudice and suspicion of him and doing that would have made them reject the letter right from the beginning. ${ }^{246}$ Origen also accepted Pauline authorship but in a wide sense. Pauline authorship is supported, among other things, by the author's emphasis on Jesus' entrance into heaven rather than on the resurrection. Yet, the differences in vocabulary, style, manner of introducing citations and in structure between Hebrews and known Pauline epistles make Pauline authorship unlikely.

Scholars consider this book as one written in a more polished and eloquent Greek than any other book in the NT. In view of this Luther proposed Apollos as the author. Apollos was an eloquent person and was very knowledgeable in Scriptures (Acts 18:24). The author of Hebrews exhibited these features. Yet, while Apollos is a possible author, we cannot conclude at conclusively that he is the one. For Harnack, Priscilla is the author of Hebrews. She refused to put down her name because she lived in a man's world. Priscilla was a Hellenistic Jew who mentored Apollos (Acts 18:26). According to this view, Priscilla had great interest in the tabernacle due to her connection with tent making (Acts 18:3) occupation and travel experiences. Though this view sounds convincing, we find the masculine participle diegoumenon ("to tell") used of the author in 11:32 as evidence against female authorship. It is therefore unlikely that Priscilla authored Hebrews.

The date of the letter is uncertain. However, the epistle is likely to have been written before the destruction of the Jerusalem Temple in $\mathrm{AD} 70$ since no hint about it is given by the author. It appears to have been penned after the early period of the persecution, when the Levitical sacrificial system was still functioning. The author attempts to interpret the Christ event in his religiously pluralistic setting. The content of the epistle shows the author's familiarity with the Hebrew Scriptures and Jewish traditions. ${ }^{247}$ The writer makes extensive use of the Hebrew text, particularly soteriological concepts. At the

\footnotetext{
${ }^{246}$ Maier, Eusebius. The Church History, 218.

${ }^{247}$ Macquarrie, Jesus Christ in Modern Thought, 161.
} 
same time, the author shows acquaintance with Greek Philosophy, particularly the thoughts of Plato and Philo. ${ }^{248}$ In view of this, William Barclay is right to contend that the writer had a dual background, from Greek and Hebrew. ${ }^{249}$

The identity of the first recipients of Hebrews cannot be known for certain. However, there is scholarly consensus that the epistle was written to Hellenistic Jews or Greek-speaking Jews of the Diaspora. There are, at least, two reasons for this view. First, the author used a lot of the OT and draws from OT laws, customs, events, and theology and the experiences of the Hebrew patriarchs to make his case. ${ }^{250}$ In chapter 11, the writer mentions a lot of Jewish faithfuls such as Abraham, Isaac, Joshua and others. Issues such as the suffering Messiah and the replacement of Levitical priesthood by a priesthood of Melchizedek's order are Jewish in nature. Jesus' superiority to Moses and teachings like Jesus helps not angels but Abraham's descendants are of interest to Jews than Gentiles. For F.F. Bruce the author's extensive use of OT for his argument helps him to "establish the finality of the gospel by contrast with all that went before it (more particularly, by contrast with the Levitical cultus), as the way of perfection, the way which alone leads people to God without any barrier or interruption of access." ${ }^{251}$ Second, the author quoted from the Septuagint, the Greek translation of the Hebrew scriptures, and so the original audience were almost certainly Jews, and most probably Greek-speaking Jews living outside Palestine. Since Jews of the Diaspora were familiar with Greek, this should not invalidate the argument that the addressees were Jews.

We therefore contend that the epistle was written to Jewish Christians, who probably were connected with the Qumran community.

\footnotetext{
${ }^{248}$ Ibid.

${ }^{249}$ William Barclay, The Letter to the Hebrews (Edinburg: The Saint Andrew Press, 1960), xiv.

${ }^{250}$ Gaebelein (ed.), The Expositor's Bible Commentary vol. 12, 4. See also Hodges, "Hebrews", 777.

${ }^{251}$ F. F. Bruce, The Epistle of Hebrews (Grand Rapids, MI: Eerdmans, 1990), 29.
} 
This community was characterized by a sectarian form of Judaism which the letter speaks against. ${ }^{252}$ The author's argument that the bitter wilderness experience was the direct consequence of unbelief supports the above position. ${ }^{253}$ It purposed to prevent the audience from falling back into Judaism. This position is supported by the author's extensive use of OT sources as well as his argument that Christianity is superior to Judaism. In totality, Hebrews is meant to demonstrate the finality of Christianity.

\section{Priesthood in the Old Testament}

The word "priest" is derived from the Greek presbyteros, often translated "elder" or the Hebrew word kohen. A "priest" is authorized to officiate at the altar and in other cultic rites for a deity. The office or position of the priest is the priesthood. Priesthood as a term could also refer to a guild of priests.

From the functions of a priest (to be discussed soon), the institution of priesthood was necessitated by the universal sinfulness of humanity. The need for a sacrifice could be traced to the early chapters of Genesis. When God created humanity in his own image and other creatures, he declared all as good (1:31). There was no evil. As the bearer of God's image, human beings were created with the ability to decide what to choose and what not to choose. Thus, humans were moral beings. This ability made humans able to sin, though they were also able not to sin in their entire life. From the Adam and Eve ate the fruit of the forbidden tree and their fall had a permanent effect on future human generations.

Since God is holy he could not just allow humanity to come to him in the state of sin unless human sin was atoned for. God's holiness means that $\mathrm{He}$ is separated from sin. God is loving and merciful and so even when humanity sinned he wanted to forgive them and to bring them back to Himself. Yet, His divine attributes

${ }^{252}$ See also Hodges, "Hebrews", 779.

${ }^{253}$ Ibid. 
of holiness and justice requires that all sins be punished adequately. Thus, while God's justice and holiness, on the one hand, demanded "Destroy them" (sinners), his love and mercy, on the other hand, cried "Save them!"254

In the midst of this situation God, by means of his love, found a way to satisfy his holiness and justice and still save sinners. His love made Him decide to suffer for the penalty of separation and death for sinners. This required a substitute, one to represent humankind. Such a being must necessarily be human because he was to die in the stead of human. Yet, at the same time, the substitute must be God so that the sacrifice would be sufficient enough to satisfy God's justice. This situation necessitated the incarnation of the Second Person of the Trinity.

Since the time for the Saviour had not come, right after the Fall, God demonstrated the concept of "a life given in exchange for a life, a ransom to redeem the captives of sin and to restore us to our Owner. ${ }^{255} \mathrm{He}$ covered Adam and Eve with the skin of an innocent animal whose life was taken for the sake our first parents who had just sinned. He also gave the first promise about the Messiah who was to come and die in our stead. Adam and Eve were barred from staying in the Paradise God had prepared for them, else they would eat the fruit of life and live forever. Not long after the fall of humanity, Cain murdered his brother, Abel. Sin began to spread throughout the world which demanded sacrifices for atonement.

Until the appropriate time when the God-human was to make the perfect sacrifice for sin, God used animal sacrifice to teach people about sin, its punishment by death, and forgiveness that comes through the death of a substitute. However, all these were temporary measures because the blood of all creatures put together was not worthy enough to satisfy the demands of God's justice. In the patriarchal period, the patriarchs, Abraham, Isaac and Jacob, were both the family/clan head

\footnotetext{
${ }^{254}$ Terry G. Peretti, A.C. George and L. Jeter Walker, A Study in the Book of Hebrews: An Independent-Study Textbook (Brussels: International Correspondence Institute, nd), 174.

${ }^{255}$ Ibid., 172.
} 
and the religious leader, representing the family/clan before God. It is for this reason that we read of the patriarchal cultic activities such as building altars and shrines, consecrating them and offering sacrifices to God. Since the patriarch exercised priestly functions based on their position within the family/clan rather than upon official consecration, their office was a form of "natural priesthood."

The priestly office was officially instituted on Mt. Sinai when God established and inaugurated Israel as a nation. The giving of the Law on Mt. Sinai and the institution of the Aaronic (Levitical) priesthood belong together. Here, God chose a Levite called Aaron (the brother of Moses) and his descendants to be priests. Admission to the priesthood in Israel was determined by genealogy. Yet, the priest was expected to be without defect (Lev. 21:6-8). The object of priestly ministry was not the people or their spiritual needs, but the cult itself, its practice and preservation. The installation of the priest was elaborate, taking as much as seven days at the tabernacle or Temple (Ex. 29; Lev. 8). The consecration of the priest included bathing and being dressed in special garments with symbols. The garment represented his mediatorial function. He was anointed with oil to invoke the Holy Spirit upon him. The priest was sanctified to serve as a priest and consecrated to offer sacrifices (Ex. 28:41; 29:9). In OT priestly tradition Moses is regarded as the last individual who approached God directly. After the establishment of the covenant, priesthood and cult at Sinai, the priests had the duty to mediate the relationship between the people and God.

Among the priests was a high priest. His roles were as follows. First, he was Israel's representative before God. He wore a breastplate with the names of the twelve tribes of Israel written on it (Ex. 28:17-21). He carried the names any time he entered the Holy Place to signify that he was there on behalf of the people $(28: 29)$. Second, the high priest also had a prophetic function. He carried the Urim and Thummim in the breastplate (28:30; Lev. 18:8) with which he could tell God's will on various matters. Third, he was to bless the people (Num. 6:26-27). Fourth, the high priest supervised the 
daily activities of the other priests and had the sole right to enter the Holy of Holies once a year to make atonement for his sins and that of the people (Lev. 16). The Holy of Holies refers to the innermost part of the tabernacle where the Ark of the Covenant was kept. The day on which the high priest had access to the Holy of Holies is referred to as the Day of Atonement (Yom Kippur). He was permitted entrance into the Holy of Holies once a year was to offer sacrifices on behalf of the people. His function was "in essence an expiatory and propitiatory." 256

\section{Why a new Priestly Order?}

OT priesthood order could not effect the reality of reconciliation between God and human due to its imperfection. It was preparatory portraying the principle of propitiatory sacrifice but not the fulfillment of that principle. That a new priestly order was anticipated in the OT is evident. ${ }^{257}$ First, the imperfect nature of the old priestly order necessitated the prediction of a new order of priesthood, of the Melchizedek order, different from the Levitical priestly order (Ps. 110:4). Secondly, there was a promise to replace the Old covenant with a new one by which God's laws will be written on the heart of people and sins will be removed forever (Jer. 31:31-34). The replacement of the old covenant with a new one alludes to the fact that there is something wrong with the first (Heb. 8:7).

Thirdly, the fact that one priest had to succeed another repeatedly (Heb. 7:23), necessitated the establishment of future priestly order which is both perfect and everlasting (Ps. 110:4). Fourthly, aside the fact of the mortality of OT priests, these priests were sinful humans who themselves needed to make sacrifices for their own sins before mediating for other people. This made their priesthood imperfect (Heb. 5: 3; 7:27). There was therefore the need for a perfect priestly order. Fifthly, the repetitive nature of the sacrifice made by OT priests pointed to inadequacies in those sacrifices to ${ }^{256}$ Robert Letham, The Work of Christ (Illinois: InterVasity Press, 1993), 107.

${ }^{257}$ The discussions that follow were gleaned from Elwell (ed.) Evangelical Dictionary of Theology, 953. 
deal fully and finally with sin (Heb. 10:1-2). There was therefore the need for a perfect, once and for all sacrifice to be made. Sixthly, by the nature of their sacrifices, OT priesthood could not achieve what they foreshadowed. Animals were made to die in the stead of human sinners as a symbol of transferring human sin to the innocent animal. But the fact is that an irrational, unintelligent animal cannot be a substitute for human being who bears God's image. For this reason, it was not possible for animal blood to take away human sin (Heb. 10:4). Clearly, OT priesthood could not accomplish atonement in the strict sense. Yet, it taught the people that sin must be atoned for by the provision of an innocent victim whose blood is shed on behalf of the sinner. It was God's means of providing for atonement for sin through blood sacrifice, until the once and for all sacrifice of Christ. Its usefulness can be seen in the fact that it kept alive the expectation of a perfect sacrifice who was to fulfill the OT promises about atonement.

\section{Priestly Christology in Hebrews}

The epistle of Hebrews stands tall among the NT epistles in terms of priestly Christology. For J. D. K. Ekem, Hebrews interprets the Christ event in a religiously pluralistic setting. ${ }^{258}$ The author attempts to reinterpret the OT concept of priesthood in the light of the Christ Event and in the end, gives brilliant construction of NT priestly order around the figure of Jesus, the Christ. Hebrews therefore moves from the known to the unknown ${ }^{259}$ in terms of priestly Christology.

The writer of Hebrews approached Christology the way John did in his gospel. Both books begin with the incarnation of Christ (John 1:1, 14; Heb. 1:1-4). Hebrews shares the Johannine threefold Christological pattern of descent from heaven, sojourn on earth, and return to heaven. From the onset, Hebrews states the divine aspect of Jesus' personality, his humiliation and his exaltation to the right

\footnotetext{
${ }^{258}$ J. D. K. Ekem, New Testament Concepts of Atonement in an African Pluralistic Setting (Accra:

SonLife Press, 2005), 95.

${ }^{259}$ Buttrick (ed), The Interpreter's Bible vol. 11, 577.
} 
hand of God (1:3). Hebrews presents Christ as the charakter (exact representation) of God's hypostasis (nature). However, Hebrews has more events happening in the middle stage (sojourn on earth) than John. As God incarnate, Jesus is the one through whom God has spoken to the world in the last days $(1: 1)$, concerning His salvific plan. His sonship has made him "heir of all things" (1:2). One of the most striking Christological themes in Hebrews is priestly Christology $(2: 17 ; 3: 1 ; 4: 14 ; 5: 5,10 ; 6: 20 ; 7: 26 ; 8: 1 ; 9: 11 ; 10: 21)$. One may be surprised considering the significant attention drawn to Christ's priesthood considering the fact that he seems to have been critical of temple practices and at odds with the Jerusalem priesthood (Mark 11:15-18). In what follows we discuss how Hebrews portrays Jesus as a high priest.

\section{Christ the Perfect High Priest}

Before this section the writer had for once referred explicitly to the priesthood of Christ (in 2:1-3:6). The opening verse states the dominant theme: "Therefore since we have a great high priest who has passed through the heavens, Jesus the Son of God" (4:14). The "therefore" in 4:14 points to our need of a high priest. The need for a high priest can be seen from vv. 12-13 which says we will be judged according to our thoughts and attitudes. Nothing can be hidden from the eyes of all-knowing God (4:13); our sins will find us out (Num. 32:23). The guilt, fear of discovery and fear of punishment points to the need for a priest to mediate between human and God. God knew of our need for a mediator and so he established the Levitical priestly order to deal with human sins. We have stated earlier that among the priests, there was one High Priest, the supervisor of the other priests, who was the only one permitted to enter the Holy of Holies and to make atonement for sins on the Day of atonement.

How does Jesus qualify as a High Priest? In 5:1ff, the author takes logical steps to highlight some qualifications of the Levitical High Priest. As we bring these qualifications out we shall at the same 
time look at whether Jesus possesses these qualities or not. First, the High Priest was "taken from among men" (5:1). This means the High Priest was expected to be human. Christ is truly and fully human, having shared our flesh and blood. Humanity was essential in Christ priestly role. As human, Christ suffered, endured temptation and tasted death (2:11-18). If he were only God he could not have been a high priest to stand in the stead of human. Second, the High Priest does not "act privately." He is expected to be the people's representative in matters related to God (5:1). Christ acts as a representative for the whole human race with whom he is identified (1:14ff). Because he knows our problems, he is well equipped to represent us before God. Third, the High Priest does not seek to appease God emptyhanded, but with the means of gifts (döra) and sacrifices (thysiai) for sins (cf. $5: 3 ; 8: 3 ; 10: 11$ ). In the same way Christ also offer sacrifice before God. Christ offered his own blood as a propitiatory offering (2:17). Fourth the High Priest is not immune from the infirmities common to humankind (5:2, cf. 4:15). Christ himself experienced human weaknesses which equipped him to sympathize with and render help to his fellow humans amidst their troubles $(1: 18)$. Jesus' humanity, being a man of the seed of Abraham (2:11-18), qualified him to sympathize with our human limitations/weaknesses (4:15). This experience is expected to make the high priest compassionate (metripathein). Finally, the High Priest does not assume the office of the high priest for his glory (5:4-5). Similarly, Christ is not seeking after his own glory as a High Priest. He emptied himself and took upon himself human nature in order to serve our interest (Phil. 2:511).

The above relationship between the Levitical high priests and Christ proves Christ's qualification as a high priest. Yet, these must be taken as typological correspondence, not absolute identification. Christ's priesthood differed from that of the Levites in a number of ways. Firstly, Christ's priesthood replaced the Levitical priesthood, being established and sealed with a special oath from God (Ps. 110:4; cf. Heb. 5:6; 7:15, 17). ${ }^{260}$ Psalm 110 anticipated a priesthood of a ${ }^{260}$ Brown, An Introduction to The New Testament, 687. Hodges, "Hebrews" in The Bible Knowledge

Commentary, 799. 
king which will be of a different manner, or order, is promised, a new and everlasting priesthood whose manifestation shall fulfill, transform, and thereby bring to an end the provisional, temporary Levitical priesthood. The oath makes Jesus a guarantee (engyos) of a better covenant. ${ }^{261}$ By his death, burial and resurrection, he provided a righteous foundation on which God could fulfill the promises of the covenant. The oath secured his permanent position as a priest and assured the superiority of a new priestly order over the old order. Since he lives forever, his priesthood is not cut off by age or death as in the case of the Levitical priesthood.

Secondly, Christ is sinless, whereas the Levitical high priests were not. Contrary to the descendant of Aaron who was prone to human failures and had to offer sacrifices for his own sins and then the people's, Christ had no need to offer sacrifices for his own sins (since he was sinless, 4:15; 7:27-28). The perfection of Christ's priesthood is rooted in his sinless earthly human life. Thus, unlike the first Adam who suffered defeat and dragged down the human race in his fall, the "Second Adam" took on flesh and lived among us without committing any sin in order to save us and to receive glorification. On the cross, Christ (the righteous) died for humanity (the unrighteous, cf. Heb. 4:15; 7:26-27, 1 Pet. 2:22-24; 3:18). Unlike the Levitical priests who had to be replaced from time to time, Jesus is a priest forever; his priesthood is permanent. Thus, Christ's priesthood is eternal, and thereby remains efficacious forever. Christ, the new high priest, transcends Aaron and all other Levitical priests in honour and dignity. Christ, the perfect high priest, appears "in God's presence on our behalf", transcending any priest who approaches God on our behalf. This thought is in line with the introductory remark that Christ is the fullest and complete revelation of God to humanity (1:13 ) immediately affirms the superiority of Christ over all that has gone before in Israel.

${ }^{261}$ Roger E. Dickson, New Testament Commentary: Romans through Revelation (Bellville: International Bible Institute, 2001), 856. 


\section{Priesthood of a better Order (Order of Melchizedek)}

Heb. 5:9-10 refers to Christ as one who "was designated by God to be the high priest in the order of Melchizedek. This kind of priesthood is eternal, superior and supreme (cf. 6:19-20). In Heb. 5:4-6, 9-10 the author introduces the subject of the change of the priesthood from the Levitical order to the Melchizedek order. The author prepares the reader's mind by, first of all, demonstrating the greatness of Melchizedek and presenting him as a prototype of Christ. This in effect will prove the superiority of Jesus' high priesthood. Three reasons are given to show the superiority of Melchizedek's priesthood over that of the Levites (7:1-10). First, Melchizedek is shown to be greater than Abraham because Abraham gave him a tithe of his booty (v. 2). Abraham was the father of the Jewish nation. The argument is that if Abraham gave him a tithe then Melchizedek was Abraham's superior (v. 7). Granted that Melchizedek was superior to Abraham it follows that Melchizedek is also superior to Levi and Aaron who were both ancestors of Abraham. The argument that "one might even say that Levi, who collects the tenth, paid the tenth through Abraham, because when Melchizedek met Abraham, Levi was still in the body of his ancestor" (v. 9-10, NIV) supports this position. The author knew that Levi did not literally pay any tithe to Melchizedek. But on the principle that an ancestor is greater than his descendants, Levi did. Second, we are told that Abraham received Melchizedek's blessing, meaning Melchizedek was superior to Abraham: "And without doubt the lesser person is blessed by the greater" (v. 7, NIV). Once again Melchizedek is shown to be greater than Abraham and for that matter the Levites. Finally, the Levites died in due course but Melchizedek lives on (v. 8). This also makes Melchizedek's priesthood superior to that of the Levites. We can add that Melchizedek's priesthood was established with an oath and it was meant to last forever (Ps. 110:4). To sum up: Melchizedek is greater than Abraham and so Melchizedek's priesthood is greater than the Levitical priesthood which came up from Abraham's lineage. Priesthood of the order of Melchizedek means priesthood that is supreme, superior and permanent. Melchizedek is 
a priest forever. The expression eis to dienekes, translated "forever' actually means "continuously", "having no end" or "uninterrupted".

Christ was appointed by God according to the order of Melchizedek (5:10 cf. Ps. 110). And as both a king and a priest, Jesus' priesthood is "according to the order of Melchizedek" (5:10) who was also both a king and a priest.

Morris' point is apt, "If Christ was a priest after the order of Melchizedek, then he was far superiorin order of priesthood to the priests in the temple." ${ }^{262}$ The priesthood of Jesus Christ, like that of Melchizedek, is permanent. Unlike human priests who died in due course, Jesus lives forever (Heb. 7:24-25). Melchizedek's priesthood did not depend on the family from which he came, so is Christ's priesthood. Christ was not a Levite but a Judah and so he did not qualify to be a priest according to the OT priestly order (7:13-14). Yet, "[c]ontrary to the necessity of Levitical priests proving their genealogy from Aaron with written records in order to qualify to be priests, [Christ] was designated priest directly from God (See Lev. 21)." ${ }^{263}$ But the new High Priest does not hold office on the basis of a regulation as to his ancestry. The Levitical priesthood is based on the Mosaic Law (7:5b), which the author later argues has been abrogated (7:11-19). The Levitical priesthood was part of the old covenant, but the new priesthood is rooted in the new covenant promised through Jerimiah (Jer. 31:31-34; Heb. 1-13). To sum up: Jesus' priesthood which comes in the order of Melchizedek is not only a legitimate priesthood but also greater than the Levitical priesthood.

Worthy of note is the fact that the author presents Christ's priesthood as the standard, not Melchizedek's. He achieves this by stating that Melchizedek was "without father, without mother, without genealogy, having neither beginning of days nor end of life, but made like unto the Son of God" (7:3). Clearly, it was not Christ who was made like Melchizedek but it was Melchizedek who was made like Christ. In this sense, Melchizedek is an illustration of

${ }^{262}$ Morris, The Cross in The New Testament, 285.

${ }^{263}$ Dickson, New Testament Commentary, 853. 
Christ. The superiority of Melchizedek's priesthood is not due to any superior merit in his personality or office. Rather, God made him like unto the Son of God so that through his priesthood we would better understand the priesthood of the Son of God. ${ }^{264}$ What we get clearly from Melchizedek's illustrative priesthood is that Christ's priesthood transcends the Levitical priesthood. Christ's priesthood has existed from eternity, Melchizedek came to illustrate it and the incarnation, death and resurrection made it a reality to us. G. Milligan sums it up "Melchizedek is thus not the first in possessing certain characteristics which the High-Priest of the New Testament afterwards possessed. Christ is first. Melchizedek is compared with Him: not He with Melchizedek. It is Christ who is clothed with the eternal qualifications exhibited in a shadowy manner in the kingpriest of the days of Abraham."265

\section{Priesthood with better Provisions}

The priesthood of Christ comes with better provisions. First, as the perfect priest, Christ brings with him a more perfect tabernacle that is pitched by God, not human (8:2). At this point, the writer seems to have applied Platonic worldview which classifies the heavenly tabernacle set up by God as true, and the earthly tabernacle as a copy, hypodeigmati and shadow, skia (8:5). Levitical priesthood is performed in an earthly model of the real heavenly sanctuary (8:5). Moses erected this tabernacle under strict divine directions (8:5). He brings to mind Exodus 25:9, 40; 26:30, which deals with the model of the heavenly tabernacle whose earthly copy Moses built. Therefore, "[t]he Levitical priests who serve this shadow sanctuary have a ministry inferior to that of Christ, even as the first covenant is inferior to the second covenant mediated by Christ." ${ }^{266}$ It is the heavenly reality that Christ's ministry is exercised. That Jesus has passed through the heavens refers to his resurrection and ascension.

\footnotetext{
${ }^{264}$ Morris, The Cross in The New Testament, 286.

${ }^{265}$ Milligan as cited by Morris, The Cross in The New Testament, 286.

${ }^{266}$ Brown, An Introduction to the New Testament, 687
} 
The writer points out that the tabernacle and its furnishings were physical illustrations of spiritual realities which Christ brings to us. The mention of the tabernacle reminds us of the days of the wilderness wanderings. Tabernacle refers to tents, home, dwelling, in this case, the one in which worship takes place (Ex. 27:21). The word alethinos ("true"), signifies true "in the sense of the reality possessed only by archetype, not by its copies." ${ }^{267}$ In the table below we compare the earthly and heavenly tabernacles.

\begin{tabular}{|l|l|}
\hline $\begin{array}{l}\text { A Better Tabernacle } \\
\text { Hebrews } 8: 2,5 ; 9: 1,7-12\end{array}$ \\
\hline Old Tabernacle & New Tabernacle \\
\hline Earthly & Heavenly \\
\hline Made by man & Made by God \\
\hline Shadow, symbol & True, reality \\
\hline For one nation & For all people \\
\hline Limited entrance & Always open to all \\
\hline Weak sacrifices & Perfect sacrifice \\
\hline Weak priests & Perfect priest \\
\hline Destructible & Indestructible \\
\hline Temporary & Eternal \\
\hline
\end{tabular}

Christ is therefore ministering in the real tabernacle. His once and for all, not continuous, sacrifice is also the real sacrifice. It is important to state that Christ did not perform any priestly role in any earthly tabernacle. God appointed priests and entrusted that work to them $(8: 4)$. Though the ministry of priests in a sanctuary made in accordance to the heavenly pattern is of great dignity, the author argues that Jesus' ministry in the heavenly archetype is incomparably greater in dignity and in worth than that of the earthly priests (8:6).

${ }^{267}$ Gaebelein (ed.), The Expositor's Bible Commentary vol. 12, 75.

${ }^{268}$ Peretti, George and Walker, A Study in the Book of Hebrews, 160 
Second, Jesus has a better ministry. The earthly ministry of Christ was to be "purification or sins" (1:3). His one for all sacrifice achieved sanctification of his people. Christ performs his ministry in heaven itself $(4: 14 ; 9: 11)$, seated at the right hand of God the Father (10:12). In the old order the high priest had access to the Holy of Holies (representing the presence of God) once a year, on the Day of Atonement, within a limited time frame under strict conditions. Contrary, Christ's ministry has opened the way to the holiest for all. Believers have access to God all the time without the need for any human mediator.

Third, there are better promises (8:6). There are at least three basic accomplishments of the new order. First, there is an inclination to obey God (as the Laws will be put in people's mind and written on their heart, 8:10). Second, there will be a firm relationship with God for God will be their God and the people will be God's (8:10). Third, there will be knowledge of God and the forgiveness of sins (8:12). People's sins will be remembered no more.

Fourth, the new priestly order comes with a better covenant. The old covenant required righteousness which the people could not attain. It promised blessing for obedience but threatened death for disobedience. The new covenant imputes righteousness on the repentant sinner and gives the ability to live a righteous life and rewards those who live righteously. In 8:13, the author declares that the old covenant is obsolete (palaioumenon) and aging and will soon disappear. Here, the fault is identified not with the covenant itself but with the people who were to show obedience to the law. The old covenant was adequate for the purpose for which it was established. Yet, it became weak because humankind could not obey the law that is associated with the covenant. The law served to direct Israel concerning what God expects them to do but it was not meant to be a means for justification. ${ }^{269}$ The new covenant transcends the nation Israel and includes all people on earth. Dickson observes as

${ }^{269}$ For recent scholarship on law and grace, see Frederick M. Amevenku and Isaac Boaheng, "Analysis of Law and Gospel in God's Salvific Plan" in ERATS vol. 2, No. 1 (2016): 188-212. 
follows: ${ }^{270}$ In the old covenant, anyone physically born a Jew became an automatic member or came into covenant relationship with God. From that time, he/she is taught as a child the conditions of the covenant while in the covenant relationship with God (cf. Isaiah 52:12-15; John 6:44-45). Contrary to this covenant, before one becomes part of the new covenant the person would have been taught the conditions of the covenant and through baptism for remission of sins, the person would have voluntarily joined the covenant relationship through the new birth (John 3:3-5; Rom. 6:3-6). In this sense, the law is written on a person's heart and mind before coming into covenant relationship with God. In short, in the old covenant membership precedes the understanding of the covenant but in the new covenant understanding the covenant and its requirement precedes membership to the covenant.

\section{Priesthood with Perfect Sacrifice}

Just as the earthly tabernacle was a shadow of the heavenly tabernacle, so were the sacrifices made in it a shadow of Christ's sacrifice on the cross. The earthly sacrifices cleansed earthly things, but for entrance into heaven, the perfect sacrifice of Christ was required. Christ enters the Most Holy Priest not with the blood of bulls and calves but with his own blood, once for the redemption of all. The sacrifice Christ offered for sins was not that of animals but his own perfect blood. The author bluntly states, "it is impossible that the blood of bulls and goats should take away sins" (Heb. 10:4). It was impossible for the blood of animals to cleanse human sins (Heb. 10:1-4 because

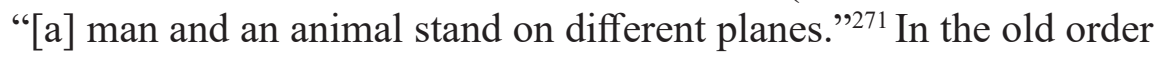
the animal was irrational but in the case of the new other the victim, Christ is a rational being who perfectly obeyed God to the end. It was not by the blood of animals that Christ entered the Holy of Holies but his own blood (Heb. 9:12) which was the perfect, complete and final sacrifice for sins; once and for all without the need for repetitive

\footnotetext{
${ }^{270}$ Dickson, New Testament Commentary, 863-864.

${ }^{271}$ Morris, The Cross in The New Testament, 292.
} 
sacrifice (Heb. 9:26, 28; 10:10, 12). Christ's sacrifice has a lasting effect: He offered one sacrifice for sin forever" (Heb. 10:12) such that "there is no more offering for sin" (Heb. 10:18). Brown says "When he offered himself, this holy, blameless, undefiled high priest, separated from sinners and exalted above the heavens, effected a sacrifice that is once for all (7:26-27)." ${ }^{272}$ This makes his offering the fulfillment of all expectations that were prefigured in the OT sacrificial system.

Paradoxically, Christ is the offering and the offerer (7:27), the victim/sacrifice and the priest, one signified in his death and the other in his resurrection and ascension, and together issuing in the atonement. The author argues that God prefers obedience to a multiplicity of sacrifices. The obedience of Jesus' sacrifice is phrased in 10:5-9 through a passage from Ps 40:7-9: "A body you prepared for me ... Behold I have come to do your will as it is written of me at the head of the book." For this reason, believers are "given a share in Jesus' own consecration; their sins are forgiven, and so there is no longer a need for offerings for $\sin ^{\text {"273 }}$ for they are made perfect.

Another paradox is the fact that even though Jesus offers not repeated sacrifices, he enjoys a permanent priesthood. If Jesus is high priest forever, there must be a sense in which he offers "sacrifices and offerings" forever, because that is the role that defines a priest. Protestants contend for "once-for-allness" and unrepeatability of the Christ's sacrifice on the cross. Catholics on the other hand, contend that Jesus continues to be a priest forever in such a way that his sacrifice on the Cross, though unrepeatable, is a perpetual reality that is not tied to a particular moment in time. The Catholics further contend that Jesus is seated at the right hand of the Father $(8: 1)$ in relation to his kingship and not his priesthood as Protestants argue. Details of this argument is beyond the scope of this study.

\footnotetext{
${ }^{272}$ Brown, An Introduction to The New Testament, 687.

${ }^{273}$ Ibid., 688.
} 


\section{Conclusion}

In Christ, both priesthood and sacrifice have been brought to fulfillment and finality. Christ became the officiating high priest over his all-sufficient, and thus once-for-all, self-sacrifice. With such a high priest, believers must approach the throne of grace with confidence. Christ has opened up the way to God by taking our sins to the Cross so that the road to God is cleared for us. He did this through his sacrifice which made propitiation for our sins. Because of what he did sins have been forgiven and all who believe are saved. Christ's priestly self-sacrifice is as weighty a matter as to be thought of as the principal point on which the whole of salvation turns. In reflecting on the priesthood of Christ we recall the idea of priesthood of all believers which was popularized by the Reformers. The priesthood of all believers has given all believers direct access to God. The sufficiency of Christ's sacrifice also means that we need no other sacrifice for our redemption. Christ our final and complete sacrifice has been made.

\section{Review Exercise}

1. How does Christ compare with a traditional African priest?

2. In what sense is the new covenant better than the old?

3. What are the significances of the atonement of Christ?

4. How is Christ the "offerer" and the offering at the same time?

5. "Christ is a priest after the order of Melchizedek." Explain.

6. Why was it necessary for a new priesthood to be established? 


\section{BIBLIOGRAPHY}

Akin, Daniel L. (ed.). A Theology for the Church. Tennessee:

B \& H Publishing Group, 2007.

Amevenku, Frederick M. and Isaac Boaheng, "Analysis of Law and Gospel in God's Salvific Plan" in ERATS vol. 2, No. 1 (2016): 188-212.

Appiah, K. A. "Akan and Euro-American Concepts of the Person" in Lee M. Brown (ed), African Philosophy: New and Traditional Perspectives. Oxford: Oxford University Press, 2004.

Arndt, William F. and F. Wilbur Gingrich, A Greek-English Lexicon of the New Testament and other Early Christian

Literature. Chicago: The University of Chicago Press, 1957. Asante, Emmanuel. Jesus the Christ: A Survey of the Christological Quest. Kumasi: Wilas Press Ltd, 2009.

Barclay, William. The Letter to the Hebrews. Edinburg: The Saint Andrew Press, 1960.

Barret, C. K. The Gospel According to St. John: An Introduction with Commentary and Notes on The Greek Text Second Edition. Philadelphia: Westminster Press, 1978.

Bauckham, Richard. Jesus and the God of Israel: God Crucified and Other Studies on the New Testament's Christology of Divine Identity. Grand Rapids: Wm. B. Eerdmans, 2008. Baumgarten, Kenneth J. A Critique of the New World Translation of the Christian Greek Scriptures' Treatment of Nine Texts Employing $\Theta \varepsilon o ́ \sigma$ in Reference to Jesus Christ. Unpublished Master's Degree Thesis, South African Theological Seminary, 2007.

Beasley-Murray, G. R. Word Biblical Commentary: John (vol. 36). Waco, TX: Word Books, 1987.

Berkhoff, Louis. Systematic Theology. Edinburg: Banner of truth, 2000. 
Blomberg, Craig L. Jesus and the Gospels. Tennessee:

Broadman and Holman Publishers, 1997.

Black, David Alan. "The Authorship of Philippians 2:6-11: Some

Literary-Critical Observations" in Criswell Theological Review 2.2 (1988) 269-289.

Boaheng, Isaac. Is the Bible Really the Word of God? Sunyani: Jonnette Secretarait, 2019.

Brown, Colin (ed.). The New International Dictionary of New Testament Theology vol. 2. Grand Rapids, MI: regency reference library, 1976.

Brown, Raymond E. "The Gospel According to John (i-xii): Introduction, Translation and Notes" in The Anchor Bible. New York: Doubledy \& Company, Inc, 1966.

An Introduction to The New Testament. New York: Doubleday, 1997.

Blomberg, Craig L. Jesus and the Gospels. Tennessee: Broadman and Holman Publishers, 1997.

Bruce, F. F. The Gospel of John. Grand Rapids: Wm. B. Eerdmans, 1983.

Philippians. San Francisco: Harper \& Row, 1983.

The Epistle of Hebrews. Grand Rapids, MI: Eerdmans, 1990.

Buttrick, George Arthur (ed.). The interpreter's Bible Vol. 8. New York: Abingdon Press, 1956.

Chapell, B. Christ-Centered Preaching: Redeeming the Expository Sermon. Kindle 2nd ed. Grand Rapids: Baker Academic, 2005.

Carson, D. A. The Gospel According to John. Grand Rapids, MI: William B. Eerdmans, 1991.

Chafer, Lewis Sperry. Systematic Theology Vol. 1\&2. Grand Rapids, MI: Kregel Publications, 1993.

Cullmann, Oscar. The Christology of the New Testament. London: SCM Press Ltd., 1967.

Daniel L. Akin (ed.), A Theology for the Church. Tennessee: B \& H Publishing Group, 2007.

Davis, John J. From Paradise Lost to Paradise Regained. Brooklyn: 
Watchtower Bible and Tract Society, 1958.

Delaney, Carol Lowery. Abraham on Trial: The Social Legacy of

Biblical Myth. Princeton: Princeton University Press, 1998.

Demarest, Gordon R. and Bruce A. Lewis, Integrative Theology vol.

2. Grand Rapids, MI: Zondervan, 1996.

Dickson, Roger E. New Testament Commentary: Romans through

Revelation. Bellville: International Bible Institute, 2001.

Douglas J. Moo, "The Letters to the Colossians and to Philemon" in

PNTC. Grand Rapids: Eerdmans, 2008.

Elwell, Walter A. (ed.) Evangelical Dictionary of Theology 2nd edition. Grand Rapid, MI: Baker Publishing, 2001.

Ekem, J. D. K. New Testament Concepts of Atonement in an African Pluralistic Setting. Accra: SonLife Press, 2005.

Enns, Paul. The Moody Handbook of Theology, revised and expanded. Chicago: Moody Publishers, 2008.

Eveson, Philip. Book of Origins. Darlington: Evangelical Press, 2001.

Felter, Peter. Gethsemane "My Father, If It Is Possible, May This

Cup be Taken from Me” Np: Xulon Press, 2012.

Gaebelein, Frank E. (ed.), The Expositor's Bible Commentary vol.

11. Grand Rapids, MI: Zondervan Publishing House, 1976.

Garland, David E. The NIV Application Commentary: Colossians/

Philemon. Grand Rapids, MI: Zondervan, 1998.

Geisler, Norman L. "Commentary on Colossians" in The Bible

Knowledge Commentary edited by

Godet, Frederick L. Commentary on the Gospel of John, 3 vols.

Grand Rapids: Zondervan, reprint, 1969.

Gorman, Michael J. Elements of Biblical Exegesis: A Basic Guide for Students and Ministers. Grand Rapids, MI: Baker Academic, 2010.

Inhabiting the Cruciform God: Kenosis, Justification, and Theosis in Paul's Narrative Soteriology. Grand Rapids, MI: Wm. B. Eerdmans Publishing Co., 2009.

Grieb, A. Katherine. "The One Who Called You: Vocation and

Leadership in the Pauline Literature," Int 59 (2005): 154-65. Grudem, Wayne A. Systematic Theology: Introduction to Christian Doctrine. Nottingham: Inter-Varsity Press, 2011. 
Guthrie, Donald. New Testament Introduction. Illinois: Inter-varsity Press, 1974.

Haight, Roger. The Future of Christology. Bloomsbury: A\&C Black, 2005.

Harris, Murray J. Exegetical Guide to the Greek New Testament:

Colossians and Philemon, second edition. Nashville: B \& H, 2010.

Hawthorne, Gerald. "Philippians" in WBC. Waco: Word, 1993. Hemsworth, William. For The Church: Essays on Ecclesiology,

Christology, and Church History. NP: Lulu.com 2017. Hendry, George S. "Christology," A Dictionary of Christian Theology, ed. Alan Richardson. London: SCM, 1969.

Hodge, Charles. Systematic Theology I (Massachusetts:

Hendrickson Publishers, 2008), 489.

Holladay, Carl R. A Critical Introduction to the New Testament:

Interpreting the Message and Meaning of Jesus Christ.

Nashville: Abingdon Press, 2005.

House, H. Wayne. "The Doctrine of Christ in Colossians" in Bibliotheca Sacra 149 (1992) 180-192.

. "Doctrinal Issues in Colossians Part 2: The Doctrine of Christ in Colossians" in BSAC 149, no. 594: 1992.

Jowers, Dennis W. "The Meaning of Morphe on Philippians 2:6-7" in JETS 49/4 (2006):739-66.

Keddie, Gordon J. An EP Study Commentary on John Vol. 1.

Auburn: Evangelical Press, 2001.

Kelly, J. N. D. Early Christian Doctrines. New York: Harper \& Brothers, 1960.

Kostenberger, Andreas J. John: Baker Exegetical Commentary on the New Testament. Grand Rapids, MI: Baker Academic, 2004.

Ladd, George Eldon. A Theology of the New Testament. Grand Rapids, MI: W. B. Eerdmans Publishing Company, 2001.

Letham, Robert. The Work of Christ. Illinois: InterVasity Press, 1993.

Louis Berkhof, Introduction to the New Testament. Grand Rapids,

MI: Christian Classics Ethereal Library, 2004.

MacArthur, John. MacArthur New Testament Commentary: John 
1-11. Chicago: Moody Publishers, 2006.

Macquarrie, John. Jesus Christ in Modern Thought (Philadelphia:

Trinity Press International, 1990.

Maier, Paul L. Eusebuis The Church History: A New Translation with Commentary. Grand Rapids, MI: Kregel Publications, 1999.

Martin, Walther. The Kingdom of the Cults. Minneapolis: Bethany publishers, 2003.

Mchugh, John F. "A Critical and Exegetical Commentary on John $1-4$ " in The International

Critical Commentary on The Holy Scriptures of The Old and New Testaments edited by G. Davies, I. and G.N. Stanton (eds.). London: T\&T Clark, 2009.

Morris, Leon. The Gospel According to John the English Text with Introduction, Exposition and Notes. Grand Rapids, Michigan: B. Eerdmans Publishing Co., 1989. . The Gospel to John. Michigan: WM. B. Eerdmans Publishing Co., 1971.

. The Cross in The New Testament. Grand Rapids, MI: W. B. Eerdmans Publishing Company, 1972.

Morey, Robert. Trinity: Evidence and Issues. Iowa Falls: World Bible Publishers Inc., 1996.

Morris, Henry M. The Genesis Record. Grand Rapids, MI: Baker Book House, 2000.

Mounce, William D. Basics of Biblical Greek 2nd Edition. Grand Rapids: Zondervan, 2003.

Needham, N. R. 2000 Years of Christ's Power: The Age of the Early Church Fathers. London: Grace Publications Trust, 2002.

O' Brien, Peter. The Epistle to the Philippians. Grand Rapids:

Eerdmans Publishing, 1991.

. Word Biblical Commentary Volume 44: Colossians, Philemon. Waco, TX: Word Books, 1982.

Osborne, Grant. Cornerstone Biblical Commentary (Volume 13):

The Gospel of John. Illinois: Tyndale House Publishers, Inc., 2007.

Pannenberg, Wolfhart. Jesus-God and Man translated by Lewis L.

Wilkins and Duane A. Priebe. Philadelphia: The Westminster 
Press, 1964.

Peretti, Terry G., A.C. George and L. Jeter Walker, A Study in the Book of Hebrews: An Independent-Study Textbook.

Brussels: International Correspondence Institute, nd.

Peppler, C. L. "The Christocentric Principle: A Jesus-Centred

Hermeneutic" Conspectus 13 no. 1 (2012):117-135 and K.

G. Smith, "The Christocentric Principle: Promise, Pitfalls, and

Proposal. Conspectus 13 no. 1 (2012):157-170.

Prenter, Regin. Creation and Redemption translated by Theodor J.

Jensen (Philadelphia: Fortress Press, 1967.

Radcliffe-Brown, A. R. et. al (eds), African Systems of Kinship and

Marriage. London/New York/Toronto: Oxford University

Press, 1975.

Robertson, A. T. Word Pictures in the New Testament vol. 5. Grand

Rapids: Baker Book House, 1932.

. A Grammar of the Greek New Testament in the Light of

Historical Research. Nashville, TN: Broadman Press, 1934.

Ryle, J. C. Expository Thoughts on John vol. 1. Edinburg: The

Banner of Truth Trust, 2009.

Schaff, Philip. History of the Christian Church vol. 3 (Grand

Rapids, MI: Wm. B. Eerdmans Publishing Company, 1910.

Silva, Moises. "Philippians" in Baker Exegetical Commentary on

the New Testament. Chicago, IL: Moody Press, 1998.

Strong, Augustus H. Systematic Theology I. Np: Delmarva

Publications, Inc., 2015.

Tate, W. Randolph. Handbook for Biblical Interpretation 2nd ed.

Grand Rapids, Michigan: Baker Academic, 2012.

Tillich, Paul. Systematic Theology, vol. 2. University of Chicago Press, 1957.

Trahan, Lucy. "Is there Scriptural Legitimacy for Jehovah's

Witnesses Christology of the 'Firstborn' as First of God's

Created Being?" Unpublished Master of Arts in Theological

Studies thesis: Concordia University, 2012.

Turner, Nigel. Grammatical Insights into The New Testament.

Edinburg: T\&T Clark, 1965.

Vaus, Will. Mere Theology: A Guide to the Thought of C. S. Lewis.

Downers Grove: InterVarsity Press, 2004. 
Verbrugge, Verlyn D. The NTV Theological Dictionary of New Testament Words, An Abridgment of New International Dictionary of New Testament Theology. Grand Rapids, MI:

Zondervan Publishing House, 2000.

Vine, W. E. Expository Dictionary of New Testament Words vol. I. New Jersey: Fleming H. Revell Company, 1966.

Vincent, Marvin. Word Studies in the New Testament vol. 3.

Massachusetts: Hendrickson Publishers, 2009.

Vine, W. E. Expository Dictionary of New Testament Words vol. IV.

New Jersey: Fleming H. Revell Company, 1966.

Wallace, Daniel B. Greek Grammar Beyond the Basics. Grand Rapids, MI: Zondervan, 1996.

Walter Msgr. Niebrzydowski, The Cosmic Countdown: God, Humanity, and the Evolving Universe. np:np, 2012.

Walvoord, John F. and Roy B. Zuck. Colorado: David C. Cook, 1983.

Warfield, B. B. The Person and Work of Christ. Philadelphia: The Presbyterian and Reformed Publishing Company, 1950.

Wiley, H. Orton and Paul T. Culberson, Introduction to Christian Theology. Kansas City: Beacon Hill Press of Kansas City, 1946.

Williams, J. Rodman. Renewal Theology: Systematic Theology from a Charismatic Perspective three volumes in one. Grand Rapids, MI: Zondervan, 1996.

Wright, N. T. The Climax of the Covenant: Christ and the Law in Pauline Theology. London: T\&T Clark Ltd., 1991. Youngblood, Ronald F. (ed). Nelson's New Illustrated Bible Dictionary. Nashville: Thomas Nelson, 1995. 


\section{SUBJECT INDEX}

Adoptionism 6, 16, 78

Apollinarianism 16,78

Arianism 6, 14, 19, 61, 78

Christ vii, vii-151, ix, 1, 2, 3, 4, 5, 6, $7,8,9,11,12,13,14,15,16$, $17,18,20,27,28,29,30,31$, $35,37,38,39,40,41,42,43$, $44,45,47,48,52,53,54,56$, $57,58,59,60,62,63,64,68$, $70,71,72,73,74,75,76,77$, $78,79,80,81,82,83,84,85$, $86,87,88,89,90,91,92,93$, 94, 95, 96, 97, 98, 99, 100, 101, 102, 103, 104, 105, 108, 110, $111,112,113,114,115,116$, $117,118,119,120,121,123$, $124,125,129,130,131,132$, $133,134,135,136,137,138$, $139,140,141,142,143,145$, 146,148

Christian vii, viii, 1, 2, 6, 7, 8, 11, 12,

$13,17,20,43,44,45,52,55$, $56,64,65,74,75,79,81,96$,

$97,102,109,111,123,142$, $144,145,147,148,151$

Christianity vii, 1, 8, 11, 12, 13, 19,

$55,62,98,103,126,151$

Christology ii, iii, vii, ix, 1, 2, 3, 4, 5, $6,7,9,10,14,16,18,19,20$, $42,43,46,47,48,57,63,64$, $65,71,77,78,79,81,96,97$, 101, 102, 103, 105, 106, 109, $117,123,130,131,142,143$, 145,147

Christology from below 5, 6, 10 Church Fathers 6, 13, 146 covenant $11,24,26,38,48,128,129$, $133,135,136,138,139,141$

creation $9,14,15,46,48,49,51,52$, $58,60,68,69,77,85,103,104$, $105,106,112,113,115,116$, $117,118,120,121$

crucifixion $37,47,79,84,89,90,98$ Day of Atonement 129, 138 divine nature $18,34,36,38,59,70$, $71,72,73,74,76,89,98$

Docetism 6, 12, 13, 19, 78

Ebionitism 6 enslavement 84

Euthychianism 17, 19, 78

exaltation ix, 9, 79, 81, 82, 83, 94, 95, 96,130

firstborn 37, 103, 104, 105, 106, 107, $108,109,113,115,116,117$,

$118,119,120,121$

humankind $3,7,8,17,30,58,77,92$, $93,127,132,138$

human nature $18,68,69,70,71,72$, $73,74,75,76,77,78,132$ humiliation ix, 9, 15, 79, 81, 82, 83, $84,89,90,92,94,100,130$ image $24,29,30,52,58,68,85,104$, $113,114,115,121,126,130$ incarnation vii, ix, 5, 9, 12, 13, 28, 43, $45,46,49,52,64,65,70,71$, $72,73,75,76,77,78,79,81$, $83,84,87,89,92,94,95,96$, $98,99,100,101,102,119,127$, 130,136

kenosis 92

kenotic theories 92,99 
Law and Prophets 4

Levitical high priests 132,133

likeness $60,82,86,87,93,99$

$\log 0$ 9, 43, 45, 48, 49, 50, 52, 53, 54,

$56,57,58,65,67,68,99,100$

Melchizedek 9, 43, 45, 48, 49, 50, 52,

$53,54,56,57,58,65,67,68$,

99,100

Messiah 9, 43, 45, 48, 49, 50, 52, 53,

$54,56,57,58,65,67,68,99$, 100

Messianic prophecies 9, 43, 45, 48, $49,50,52,53,54,56,57,58$,

$65,67,68,99,100$

Monarchianism 9, 43, 45, 48, 49, 50,

$52,53,54,56,57,58,65,67$,

$68,99,100$

Monophysitism 9, 43, 45, 48, 49, 50,

$52,53,54,56,57,58,65,67$,

$68,99,100$

Monothelitism 9, 43, 45, 48, 49, 50,

$52,53,54,56,57,58,65,67$,

$68,99,100$

Mosaic Law 9, 43, 45, 48, 49, 50, 52, $53,54,56,57,58,65,67,68$,

99,100

Nestorianism 6, 17, 19, 78

new covenant $9,43,45,48,49,50$,

$52,53,54,56,57,58,65,67$,

$68,99,100$

Old covenant $9,43,45,48,49,50,52$, $53,54,56,57,58,65,67,68$,

99,100

Parousia 9, 43, 45, 48, 49, 50, 52, 53,

$54,56,57,58,65,67,68,99$, 100

pre-existence $9,43,45,48,49,50,52$,

$53,54,56,57,58,65,67,68$,

99,100

priesthood $9,43,45,48,49,50,52$,
$53,54,56,57,58,65,67,68$, 99,100

Sabellianism 9, 43, 45, 48, 49, 50, 52, $53,54,56,57,58,65,67,68$, 99,100

sacrifice $9,43,45,48,49,50,52,53$, $54,56,57,58,65,67,68,99$, 100

sacrificial death $9,43,45,48,49,50$, $52,53,54,56,57,58,65,67$, $68,99,100$

salvation $9,43,45,48,49,50,52,53$, $54,56,57,58,65,67,68,99$, 100

Saviour 9, 43, 45, 48, 49, 50, 52, 53, $54,56,57,58,65,67,68,99$, 100

self-emptying $9,43,45,48,49,50$, $52,53,54,56,57,58,65,67$, $68,99,100$

Septuagint 9, 43, 45, 48, 49, 50, 52, $53,54,56,57,58,65,67,68$, 99,100

Son of God 9, 43, 45, 48, 49, 50, 52, $53,54,56,57,58,65,67,68$, 99,100

superiority $9,43,45,48,49,50,52$, $53,54,56,57,58,65,67,68$, 99,100

Tabernacle 9, 43, 45, 48, 49, 50, 52, $53,54,56,57,58,65,67,68$, 99,100

the angel of the LORD 9, 43, 45, 48, $49,50,52,53,54,56,57,58$, $65,67,68,99,100$

theanthropic nature $9,43,45,48,49$, $50,52,53,54,56,57,58,65$, $67,68,99,100$

theos $9,43,45,48,49,50,52,53,54$, $56,57,58,65,67,68,99,100$ 
THIS COPY IS NOT FOR SALE

Essays In Exegetical Christology | 149 


\section{ABOUT AUTHORS}

Frederick Mawusi Amevenku is an ordained Minister of the Evangelical Presbyterian Church,Ghana. He is a Senior Lecturer in New Testament and Biblical Hermeneutics at the Trinity Theological Seminary, Legon in Accra, Ghana. He holds a PhD from Stellenbosch University (Western Cape), South Africa. Mawusi also holds BD and MTh degrees from Trinity Theological Seminary, Legon; LLB and MPhil degrees from the University of Ghana, Legon and Dip. Ed and B.Ed degrees from the University of Cape Coast, Ghana. He has served as District Pastor twice in the Evangelical Presbyterian Church Ghana. He edited A Handbook for Presbyters (2016), Coauthored Tithing in the Christian Church (2018) and edited Topics in Discipleship Series (2019). Mawusi has published many articles in refereed journals and contributed chapters to a few books in the areas of New Testament Studies, Mother Tongue Theologising and Biblical Interpretation. Mawusi is married to Dzifa and they live together with their son Elorm.

Isaac Boaheng holds a Master of Divinity Degree from the Trinity Theological Seminary. He is an ordained minister of the Methodist Church Ghana and a Translator with the Bible Society of Ghana. Some of his recent publications include: A Study of Amos and Hosea: Implications for African Public Theology (2020); Is the Bible Really the Word of God (2019) and Basic Biblical Hebrew (2019). Isaac has research interest in Public Theology, Biblical Studies, and African Christianity. He is married to Gloria and they are blessed with Christian, Benedict and Julia. 